Академия наук Республики Башкортостан

ФГОУ ВПО Башкирский государственный аграрный университет

Р.Р. ИСМАГИЛОВ

Л.М. АХИЯРОВА

\title{
КОРМОВЫЕ КАЧЕСТВА ЗЕРНА ОЗИМОЙ РЖИ
}

Уфа «Гилем» 2012 


\section{УДК 63}

ББК 4

И85

Исмагилов Р.P., Ахиярова Л.М.

Кормовые качества зерна озимой ржи. - Уфа: Гилем, 2012. - 116 с. ISBN 97-5-7501-1381-1

Рецензент: доктор сельскохозяйственных наук Хазиахметов Ф.С.

ISBN 97-5-7501-1381-1

(C) Исмагилов Р.Р., Ахиярова Л.М., 2012

(C) АН Рб, издательство «Гилем». 2012 


\section{ВВЕДЕНИЕ}

Озимая рожь имеет ряд преимуществ перед другими зерновыми культурами. Главное из них - экологическая пластичность и относительная нетребовательность к условиям произрастания. Она успешно произрастает и стабильно формирует высокую урожайность на обширной территории Российской Федерации со сравнительно низкой обеспеченностью природными ресурсами. Кроме того, озимая рожь является хорошим предшественником для многих культур. Возделывание озимой ржи позволяет разгрузить пиковые нагрузки на машинно-тракторный парк и рабочие ресурсы хозяйства и тем самым сократить затраты. Зерно ржи отличается большим содержанием ряда ценных питательных веществ, в частности, незаменимой аминокислоты лизин. В целом, возделывание озимой ржи в средней полосе страны экономически, агротехнически и экологически целесообразно. В этой связи возникает необходимость расширения использования зерна ржи.

Одним из нереализованных направлений в Российской Федерации остается использование зерна озимой ржи на кормовые цели. Всего 8-10\% зерна ржи используется для кормовых целей от валового его сбора. Рекомендуется вводить зерно ржи в рацион кормления крупного рогатого скота не более $30 \%$ и свиней - $10 \%$. Это связано со сравнительно низкой поедаемостью и усвояемостью животными питательных веществ зерна ржи.

В нашей стране целенаправленные исследования антипитательных веществ и их роли в формировании кормовых свойств зерна практически не проводились. Недостаточно раскрыты закономерности изменения содержания антипитательных веществ и имеющаяся научная информация не позволяет разрабоать эффективную технологию производства кормов из зерна ржи и вести селекцию сортов для кормовых целей. Пентозаны в последние годы в нашей стране рассматриваются как основной антипитательный фактор. Академиком РАСХН А.А. Гончаренко проводится селекция сортов ржи для разного целевого назначения [1998, 2000, 2001, 2009, 2012].

Учитывая недостаточность информации в отечественной научной литературе о кормовых свойствах зерна ржи, в предлагаемой книге обобщены результаты исследований зарубежных и отечественных авторов, а также исследований, проведенные нами в последние годы.

Результаты исследования, изложенные в данной книге, получены в рамках ГНТП Академии наук РБ «Ресурсосберегающие технологии 
производства высококачественного продукции растениеводства» и гранту Министерства сельского хозяйства РФ «Свойства пентозанов и кормовые качества зерна ржи».

\section{1. ПИТАТЕЛЬНАЯ ЦЕННОСТЬ ЗЕРНА ОЗИМОЙ РЖИ}

\section{1. Зерно ржи в рационе кормления сельскохозяйственных животных}

Зерно ржи по питательной и энергетической ценности, содержанию биологически активных веществ - ценный концентрированный корм для сельскохозяйственных животных [Аллабердин И.Л., 2006]. В то же время в последние годы на кормовые цели расходуется всего 8-10\% от общего объема производства зерна ржи в России. По существующим рекомендациям предельно допустимая доля ржи в составе комбикормов для жвачных животных, свиней и птицы составляет соответственно 20-30, 20 и 5-7\%, то есть суточная норма скармливания зерна ржи составляет 1,5; 0,6 и 0,005-0,007 кг [Мазник А.П., Хазина 3.И., 1982; Нормы и рационы кормления ...,1985; Крохина В.А., 1990; Щеглов В.В., 1990; Солошенко В.А., Филатов В.И, Рогачев В.А., 1998; Коробов А.П., 2003; Кедрова Л., 2003; Сысуев А.В., 2004а, 2004в].

Таблица 1

Нормы ввода зерновых компонентов в комбикорма для разных групп животных и птицы, \% [Крохина В.А., 1990]

\begin{tabular}{|l|c|c|c|c|}
\hline \multicolumn{2}{|c|}{ Группа животных } & \multicolumn{4}{|c|}{ От массы комбикорма } \\
\cline { 2 - 5 } & пшеница & рожь & ячмень & овес \\
\hline $\begin{array}{l}\text { Коровы и телки старше 12 месяцев, } \\
\text { нетели }\end{array}$ & 30 & 20 & 70 & 30 \\
\hline Быки-производители & 30 & 10 & 70 & 20 \\
\hline Откорм крупного рогатого скота & 30 & 20 & 70 & 30 \\
\hline Свиноматки супоросные & 30 & 10 & 70 & 20 \\
\hline Хряки-производители & 30 & 10 & 70 & 20 \\
\hline Откорм свиней (40-70 кг живой массы) & 30 & 20 & 70 & 20 \\
\hline
\end{tabular}




\begin{tabular}{|c|l|l|l|l|}
\hline Куры: взрослая птица & 70 & 7 & 50 & 40 \\
молодняк & 60 & 5 & 40 & 30 \\
\hline
\end{tabular}

На практике же доля зерна ржи в концентрированных кормах, вырабатываемых комбикормовой промышленностью страны, ограничивается 3 5\%. Вместе с тем имеются данные, свидетельствующие о том, что рожь можно использовать в больших количествах [Озимая рожь..., 2007].

Опытными данными НИИСХ Северо-Востока совместно с Кировской лугоболотной станцией ВНИИ кормов доказано, что зерно озимой ржи ценный кормовой продукт. В рацион кормления молодняка крупного рогатого скота оно может быть введено 30\% общего объема концентратов в обычном виде и до $70 \%$ - в экструдированном [Сысуев А.В., 2004а]. Правомерность результатов эксперимента подтверждает использование во многих передовых хозяйствах области значительного количества зерна ржи на фуражные цели. Так, в СПК «Октябрьский» Кумёнского района на откорме молодняка, наряду с овсом и ячменем, в концентрат включают до $30 \%$ ржаного компонента. Для дойного стада используют осоложенный ржаной корм в количестве 0,5 кг в день, что способствует увеличению надоев молока на одну фуражную корову до 6370 кг в год при поголовье 1700 коров.

В ВИЖе изучали эффективность использования рожьсодержащих комбикормов при доращивании молодняка крупного рогатого скота от 150 до 270 кг живой массы. На долю ржи в контрольном и опытных комбикормах приходилось соответственно 0, 20, 30 и 40\% по массе. Исследования показали, что среднесуточный прирост во всех группах был примерно одинаковым (879836 г), но наблюдалась тенденция к их снижению с возрастанием количества ржи в рационе. Во втором опыте изучали влияние скармливания ржи в составе комбикормов в количестве 0, 20, 40 и 50\% на откармливаемых бычках с начальной массой до 255 кг. Согласно полученным в эксперименте данным, только при максимальном вводе ржи в комбикорм (60\%) наблюдалась тенденция к снижению (на 4,7\%) среднесуточного прироста массы у бычков и увеличению затрат корма на единицу прироста [Использование..., 1998].

Имеются сведения, что удельный вес ржи в составе комбикормов для свиней может быть повышен до 50\% [Солошенко В.А., Филатов В.И., Рогачев B.А., 1998], при этом значительного снижения привеса не отмечается. С целью уточнения норм ввода ржи в полнорационные комбикорма для свиней на откорме в ВИЖе был проведен опыт на четырех группах животных. Опытные свиньи получали рацион, в котором в качестве зернового концентрата использовали ячмень. В опытных группах животных 20, 30 и 40\% ячменя рациона заменяли рожью. В результате исследований установлено, что введение в комбикорма ржи вместо ячменя в количестве до 40\% не оказало какого-либо влияния на результаты откорма свиней. Затраты корма на 1 кг прироста также были примерно одинаковыми с контрольной группой животных.

В рационы кормления сельскохозяйственной птицы введение ржи по одним литературным данным не рекомендуется [Девяткин А.И., 1990], по 
другим [Солошенко В.А., Филатов В.И., Рогачев В.А., 1998] - рекомендуется в количестве 5-7\% по массе. С целью определения сравнительной эффективности использования пшеницы, тритикале и ржи в комбикорме для цыплят-бройлеров ВНИИ кормов был проведен опыт. В рецептуре кормосмесей зерновая часть комбикорма ПК-2 для цыплят-бройлеров первой группы (контроль) содержала $20 \%$ кукурузы, $32 \%$ пшеницы и 10\% муки ячменной (дерть), в то время как во второй группе все $62 \%$ зерновой части были представлены пшеницей, в третьей - тритикале, а в четвертой - $20 \%$ кукурузы и $42 \%$ ржи (таблица 2 ).

Таблица 2

Состав и питательность кормосмесей, \%

\begin{tabular}{|l|c|c|c|c|}
\hline \multirow{2}{*}{\multicolumn{1}{|c|}{ Культура }} & \multicolumn{4}{|c|}{ Варианты опыта } \\
\cline { 2 - 5 } & ПК-2 & пшеница & тритикале & рожь \\
\hline Рожь & - & - & - & 42 \\
\hline Тритикале & - & - & 62 & - \\
\hline Кукуруза & 20 & - & - & 20 \\
\hline Пшеница & 32 & 62 & - & - \\
\hline Мука ячменная & 10 & - & - & - \\
\hline Шрот подсолнечниковый & 23,5 & 23,5 & 23,5 & 23,5 \\
\hline Дрожжи кормовые & 5 & 5 & 5 & 5 \\
\hline Мука рыбная & 6 & 6 & 6 & 6 \\
\hline Фосфат & 1 & 1 & 1 & 1 \\
\hline Мука известковая & 1,5 & 1,5 & 1,5 & 1,5 \\
\hline Премикс ПК-5-1 & 1 & 1 & 1 & 1 \\
\hline Метионин (г/100 г) & 0,3 & 0,3 & 0,3 & 0,3 \\
\hline В 100 г кормовой смеси & & & & \\
содержится: & & & & \\
обменная энергия, МДж & 1,297 & 1,261 & 1,217 & 1,200 \\
сырой протеин, \% & 23,3 & 24,3 & 23,6 & 23,3 \\
клетчатка, \% & 5,7 & 6,1 & 7,0 & 7,2 \\
фосфор, г & 1,0 & 1,1 & 1,3 & 1,3 \\
\hline
\end{tabular}

Белковые, минеральные корма и премикс во всех группах имели одинаковый процент ввода. Содержание контролируемых питательных веществ по вариантам существенно не различалось и соответствовало нормативам, кроме клетчатки. Коэффициенты переваримости питательных веществ приведены в таблице 3.

Таблица 3

Коэффициенты переваримости питательных веществ рационов, \%

\begin{tabular}{|c|c|c|c|c|}
\hline \multirow{2}{*}{ Питательные вещества } & \multicolumn{4}{|c|}{ Группа } \\
\cline { 2 - 5 } & первая & вторая & третья & четвертая
\end{tabular}




\begin{tabular}{|l|c|c|c|c|}
\cline { 2 - 4 } \multicolumn{1}{c|}{} & (контроль) & & & \\
\hline Сухое вещество & 64,0 & 62,8 & 60,2 & 60,8 \\
\hline Зола & 21,5 & 26,9 & 28,5 & 33,9 \\
\hline Органические вещества & 69,9 & 65,6 & 62,3 & 62,7 \\
\hline Протеин & 86,0 & 85,0 & 86,9 & 85,7 \\
\hline Жир & 57,6 & 49,0 & 48,4 & 53,1 \\
\hline Клетчатка & 19,1 & 23,6 & 21,8 & 24,2 \\
\hline БЭВ & 68,8 & 69,5 & 63,9 & 60,2 \\
\hline
\end{tabular}

Переваримость сухого вещества составляла 60,21-64,02\%. Особенно заметно снижалась переваримость БЭВ в вариантах с тритикале $-63,87 \%$ и с рожью - 60,16, против $68,76 \%$ в контроле. Это, по-видимому, связано с биохимическими различиями крахмала ржи по сравнению с крахмалом пшеницы. Жир хуже переваривался в комбикорме с пшеницей и тритикале. Достоверных различий в переваримости протеина не наблюдалось. Увеличение в комбикорме опытных групп сырой клетчатки сопровождалось увеличением ее переваримости с $19,1 \%$ в контроле до $24,2 \%$ в варианте с рожью. Особенности использования азота и усвоения аминокислот показаны в таблице 4.

Таблица 4

Баланс азота и усвояемость аминокислот

\begin{tabular}{|c|c|c|c|c|}
\hline \multirow[b]{2}{*}{ Показатели } & \multicolumn{4}{|c|}{ Группа } \\
\hline & $\begin{array}{c}\text { первая } \\
\text { (контроль) }\end{array}$ & вторая & третья & четвертая \\
\hline Задано с кормом, г & 52,1 & 57,4 & 53,3 & 51,9 \\
\hline Выделено с пометом, г & 27,3 & 31,1 & 28,1 & 28,8 \\
\hline в том числе мочевая кислота, г & 13,64 & 13,96 & 13,91 & 13,91 \\
\hline Переваримость, Г & 44,8 & 48,8 & 46,3 & 44,5 \\
\hline Усвоено, г & 24,8 & 26,3 & 25,2 & 23,1 \\
\hline Использовано, \% от принятого & 47,6 & 45,8 & 47,3 & 44,5 \\
\hline $\begin{array}{l}\text { Использовано, \% от } \\
\text { переваренного }\end{array}$ & 55,3 & 53,9 & 54,5 & 51,9 \\
\hline \multicolumn{5}{|c|}{ Усвояемость аминокислот, \% } \\
\hline Лизин & 83,5 & 81,5 & 79,7 & 77,8 \\
\hline Метионин & 89,9 & 89,6 & 86,0 & 82,5 \\
\hline Треонин & 77,3 & 77,7 & 78,9 & 78,5 \\
\hline В алин & 80,1 & 80,3 & 77,6 & 70,9 \\
\hline Изолейцин & 82,5 & 82,4 & 78,1 & 74,3 \\
\hline Лейцин & 83,6 & 82,7 & 80,7 & 81,7 \\
\hline Фенилаланин & 83,5 & 82,9 & 83,9 & 83,6 \\
\hline Гистидин & 79,1 & 47,5 & 70,9 & 69,7 \\
\hline Аргинин & 83,0 & 82,7 & 83,7 & 83,0 \\
\hline
\end{tabular}




\begin{tabular}{|l|l|l|l|l|}
\hline Сумма аминокислот, & 81,9 & 80,0 & 79,9 & 78,8 \\
в том числе незаменимых & 82,5 & 81,6 & 79,9 & 77,9 \\
\hline
\end{tabular}

Приведенные данные свидетельствуют о том, что наименьшая усвояемость и использование азота цыплятами наблюдалась в варианте с рожью. Можно предположить, что это связано с действием ингибитора трипсина, так как его антипитательные свойства проявляются на стадии усвоения белка. Подтверждением служат данные по усвояемости отдельных аминокислот. Так, в сравнении с контролем усвояемость, например, лизина снижалась во второй группе на $2 \%$, в третьей - на $3,8 \%$, в четвертой - на $5,7 \%$; метионина в третьей - на $3,9 \%$, в четвертой - на 7,4\%; валина в третьей - на 2,5 , в четвертой - на 9,2\%; гистидина во второй группе - на 4,63, в третьей - на 8,2 и в четвертой - на 9,4\%. Та же тенденция справедлива для доступности общей суммы аминокислот. Во второй группе она была ниже по сравнению с контролем на $1,9 \%$, в третьей - на 2 , в четвертой - на $3,1 \%$ и незаменимых аминокислот - на 0,$9 ; 2,6$ и 4,6\% соответственно.

Состав корма оказал влияние на прирост цыплят, затраты корма и протеина (таблица 5). В первых трех группах получен практически одинаковый прирост массы цыплят.

Таблица 5

Результаты выращивания цыплят и показатели контрольного убоя

\begin{tabular}{|l|c|c|c|c|}
\hline \multirow{2}{*}{\multicolumn{1}{|c|}{ Показатели }} & \multicolumn{4}{|c|}{ Группа } \\
\cline { 2 - 5 } & $\begin{array}{c}\text { первая } \\
\text { (контроль) }\end{array}$ & вторая & третья & четвертая \\
\hline Масса одной головы, г: & 239 & 238 & 240 & 238 \\
$\begin{array}{l}\text { на начало опыта } \\
\text { на конец опыта }\end{array}$ & 1935 & 1876 & 1874 & 1685 \\
\hline Прирост массы одной & & & & \\
головы за опыт, г & 1696 & 1638 & 1634 & 1447 \\
\hline Среднесуточный прирост, г & 43,48 & 42,00 & 41,90 & 37,10 \\
\hline Затраты на 1 кг прироста: & & & & \\
корма, кг & 2,34 & 2,35 & 2,38 & 2,67 \\
сырого протеина, г & 546 & 596 & 563 & 756 \\
\hline Убойный выход, \% & 69,52 & 69,01 & 70,19 & 69,04 \\
\hline Масса от тушки, \%: & & & & \\
печени & 2,66 & 2,92 & 3,02 & 3,05 \\
поджелудочной железы & 0,29 & 0,30 & 0,32 & 0,34 \\
\hline
\end{tabular}

Прирост на одну голову в четвертой группе был ниже, чем в первой и второй группах на $14,7 \%$ и на $11,5 \%$, чем в третьей. Достоверная разница получена также по затратам корма и протеина. На 1 кг прироста при введении в 
рацион ржи в количестве $42 \%$ затраты корма увеличились на 14,1 , а протеина на $38,46 \%$.

Введение в кормосмесь $42 \%$ ржи значительно снижает все хозяйственноэкономические показатели. По сравнению с контролем продуктивность птицы ниже на 14,7\%, затраты корма на 1 кг прироста выше на 14,4, а протеина - на $38,5 \%$.

Ряд опытов по скармливанию ржи животным в составе комбикормов для определения питательности ржи в рационах свиней и крупного рогатого скота были проведены в Германии [www.ryebelt.com]. В первом опыте по откармливанию были использованы 150 поросят в возрасте 55 дней.

Полученные экспериментальные данные представлены на графиках (рисунок 1, 2 и 3). Анализируя эти данные сделаны следующие выводы в пользу ржи в рационах свиней на откорме.

1. Прирост живой массы свиней на начальной стадии откорма не отличается в ржаной и ячменной группе. Но на заключительных стадиях откорма поросята из ржаной группы показывают существенную прибавку в массе до 200 г в сравнении с животными из ячменной группы (рисунок 1).

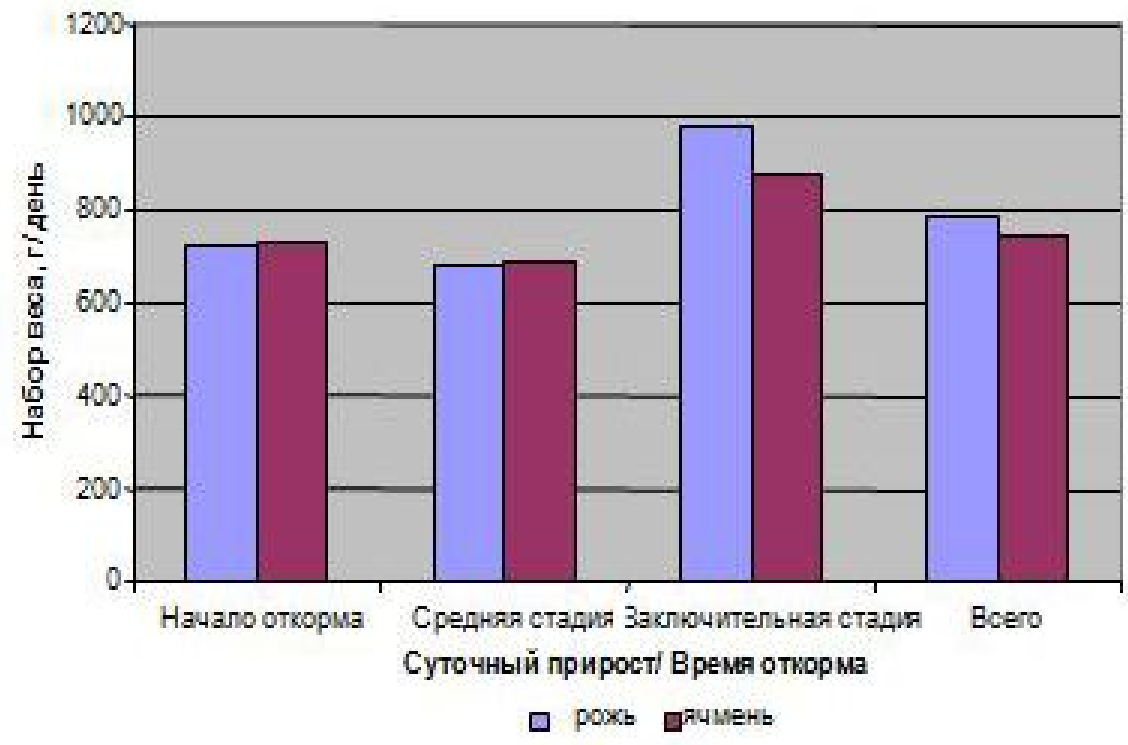

Рисунок 1. Среднесуточный прирост свиней по стадиям

2. В количестве потребленного корма на начальной стадии откорма не было отмечено различий между ржаной и ячменной группой. На заключительной стадии откорма животные из ржаной группы потребляли больше корма, чем животные из ячменной группы, что положительно сказалось в дальнейшем на привес (рисунок 2). 


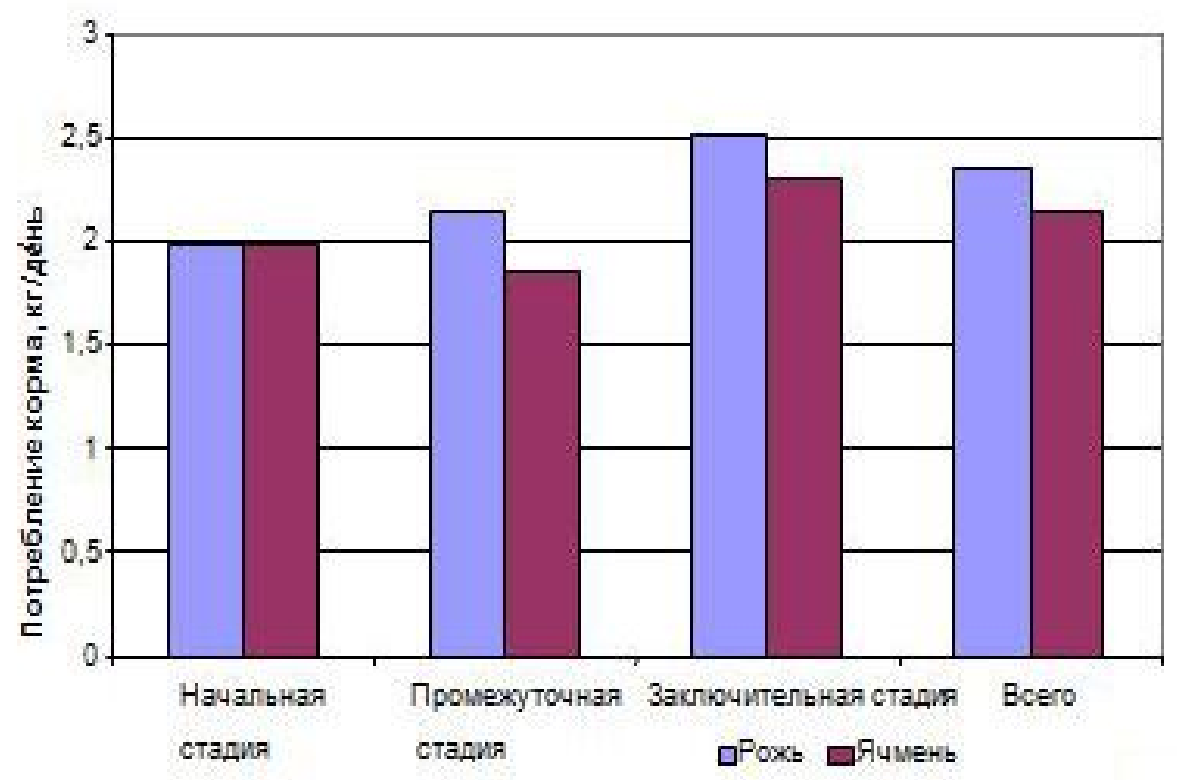

Рисунок 2. Ежедневное потребление корма в рационах свиней

3. По качеству мяса у свиней, отправленных на забой, были установлены следующие отличия в пользу из ржаной группы: у этих поросят отмечалось большее содержание обезжиренного мяса - класс S (по классификации свиных туш в Евросоюзе) нежели у поросят из ячменной группы, соответственно получен больший экономический эффект (рисунок 3 ).

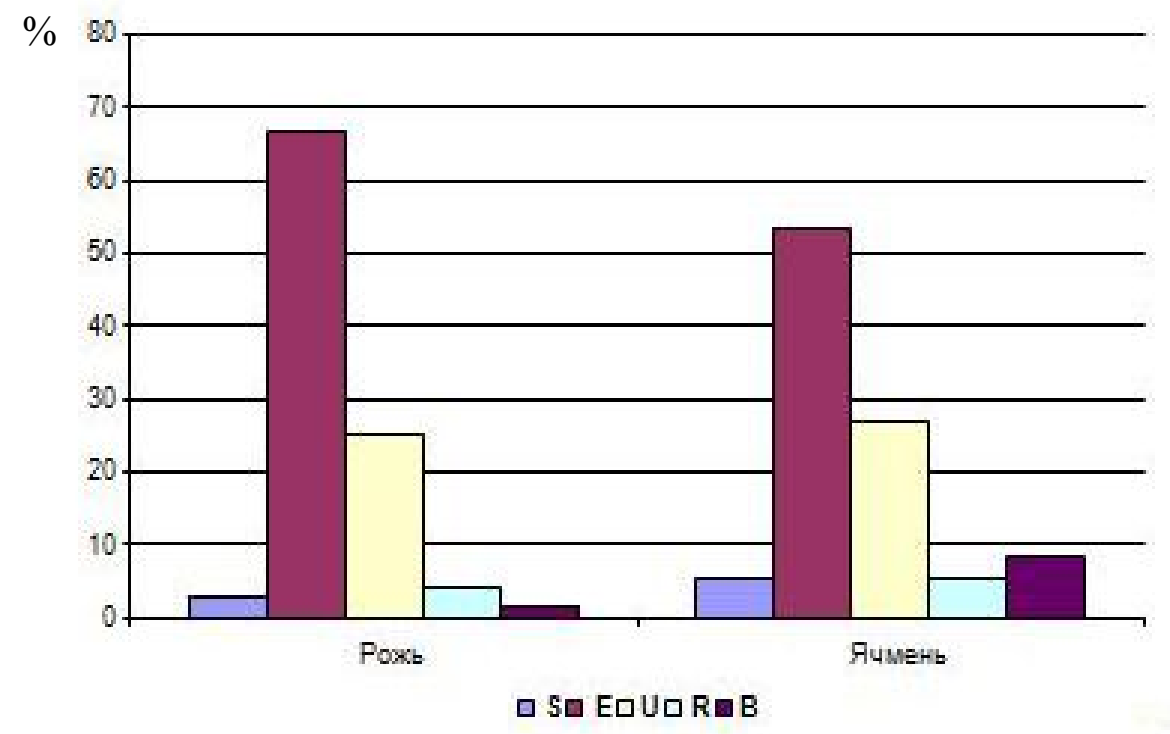

Обозначения: $S$ - содержание нежирного мяса больше 60\%, E-56-60\%, U - 51-55\%, $R-46-50 \%, B-$ меньше $40 \%$.

Рисунок 3. Количество свиней на забой в EUROP-классах 
В соответствии с рекомендациями Немецкого сельскохозяйственного общества [DLG, 2006] в рационах свиней рожь может достигать 50\% (таблица 6).

Таблица 6

Рекомендации по использованию ржи в кормлении свиней (DLG, 2006]

\begin{tabular}{|l|c|}
\hline \multicolumn{1}{|c|}{ Группа животных } & до ...\% ржи в рационе \\
\hline Свиньи на откорме: & 30 \\
28-40 кг (предварительный откорм) & 40 \\
40-60 кг (начало откорма) & 50 \\
от 60 кг (средняя стадия откорма) & 50 \\
от 90 кг (заключительная стадия откорма) & 25 \\
\hline Свиноматки & \\
\hline Поросята: & 10 \\
до 15 кг & 20 \\
от 15 кг & \\
\hline
\end{tabular}

Чтобы ответить на вопрос, возможно ли использование ржи и в рационе молочных коров проведено ипытание Сельскохозяйственной палатой земли Шлезвиг-Голштинии продолжительностью 73 дня [Mahlkow K., 2005].

К эксперименту были привлечены 36 коров, находящихся в начале периода, и 36 коров - в конце периода лактации, которые получали корм, содержащий соответственно 44\% пшеницы или ржи. Рацион с преобладанием травяных компонентов содержал в пересчете на 1 кг сухой массы 7,1 Мдж НЭЛ и 161 г усвояемого сырого белка (для группы получавшую пшеницу) и 159 г (для группы получавшую рожь).

Анализ качества молока (содержание жира, белка, лактозы) у подопытных животных не показал существенные различия животных из групп «Пшеница» и «Рожь» (таблица 7). Это позволяет сделать вывод, что введение ржи в рацион молочных коров не оказывает негативного влияния на качество молока. Кроме того, соотношение белка и жира в молоке у животных из группы «Рожь» является наиболее оптимальным.

Таблица 7

Показатели качества молока по результатам эксперимента, 2004

\begin{tabular}{|l|c|c|c|c|}
\hline \multirow{2}{*}{ Показатели } & \multicolumn{2}{|c|}{ Опытная группа «Рожь» } & \multicolumn{2}{|c|}{$\begin{array}{c}\text { Опытная группа } \\
\text { «Пшеница» }\end{array}$} \\
\cline { 2 - 5 } & $\varnothing$ & $\mathrm{SD}$ & $\varnothing$ & $\mathrm{SD}$ \\
\hline Жир, \% & $4,2^{\text {a }}$ & 0,53 & $4,0^{\mathrm{b}^{*}}$ & 0,46 \\
\hline Белок, \% & 3,4 & 0,27 & 3,4 & 0,24 \\
\hline
\end{tabular}




\begin{tabular}{|l|c|c|c|c|}
\hline Белок : жир & $1,25^{\mathrm{a}^{*}}$ & 0,14 & $1,19^{\mathrm{b}^{*}}$ & 0,14 \\
\hline Лактоза, \% & 4,8 & 0,13 & 4,8 & 0,13 \\
\hline
\end{tabular}

Польский институт животноводства на базе экспериментального хозяйства в Павловице в 2010 и 2011 году исследовал влияние применения зерна гибридной ржи на молочную продуктивность и состав молока в молочном животноводстве [KWS LOCHOW POLSKA, 2010-2011]. Были поставлены эксперименты с использованием комбикорма, содержащего $25 \%$ и $40 \%$ ржи. В опытной группе рацион кормления отличался лишь концентрацией ржи. Экспериментальные данные показали, что примешивание в корм $25 \%$ или $40 \%$ зерна ржи не оказало влияние на удои и на содержании жира и белка в молоке.

Два эксперимента по откорму, проведенные баварским земельным ведомством сельского хозяйства [Preißinger W., 2003; Preißinger W., 2004], подтверждают, что можно без ущерба для продуктивности возможно кормить молочных коров комбикормом, содержащим 30 и 60\% ржи.

В соответствии с рекомендациями Немецкого сельскохозяйственного общества [DLG, 2006] в рационах КРС рожь может достигать 40\% (таблица 8).

Таблица 8

Рекомендации по использованию зерна ржи в кормлении КРС

[DLG, 2006]

\begin{tabular}{|l|c|}
\hline \multicolumn{1}{|c|}{ Группа животных } & до ...\% зерна ржи в составе кормов \\
\hline Телята & $5-8$ в корме \\
\hline Молодняк & 40 в концентрированном корме \\
\hline Мясные коровы & $\begin{array}{c}20 \text { в концентрированном корме (макс. 1,0 кг } \\
\text { зерна ржи в день) }\end{array}$ \\
\hline Дойные коровы & 40 в рационе (макс. 4,0 кг зерна ржи в день) \\
\hline
\end{tabular}

Результаты исследований польских, голландских, немецских и российских ученых показывают, что при определенной обработке зерна озимой ржи ферментными препаратами, различными химическими и биологическими добавками, при использовании физических способов обработки зерна (дробление, экструдирование, микронизация и др.) можно повысить питательность и усвояемость ржи, увеличив ввод ее в комбикорма до 60-80\%.

\section{2. Питательная ценность зерна ржи}

Питательные вещества корма, а также вещества, синтезируемые микрофлорой пищеварительных органов, необходимы животному как источник 
энергии для жизнедеятельности организма, структурного материала, необходимого для восстановления веществ, разрушаемых в процессе диссимиляции, для образования новых тканей, для синтеза составных частей молока лактирующих животных, отложения в теле резервных веществ растущих и откармливаемых животных, как источник веществ, участвующих в регуляции обмена веществ и поддержании в определенном физико-химическом состоянии тканей и жидкостей тела животного организма.

Питательность кормов оценивают по химическому составу, переваримости питательных веществ и по количеству энергии [Доброхотов Г.Н., 1967; Леснов А.П., 2006]. Содержание белка и незаменимых аминокислот в зерне служит одним из основных показателей его питательной ценности [Тиунов А.Н., 1969; Кобылянский В.Д., 1982].

Питательная ценность и качество зерна зависят от сорта, сроков их уборки, условий произрастания и в том числе уровня минерального питания, условий хранения [Волкова Н.М., 1971; Перминова И.Г., 2003; Мотовилов К.Я., 2004]. Некоторые из факторов будут рассмотрены в этой книге.

\subsection{1. Энергетическая питательность зерна озимой ржи}

Энергетическая питательность кормов принято оценивать по содержанию обменной энергии (ОЭ) и энергетической кормовой единице (ЭКЕ). За 1 ЭКЕ принято 10 МДж обменной энергии в 1 кг корма.

По концентрации энергии (13,3 МДж/кг) рожь превосходит овес и ячмень [Сагадатов Р.P., 1990; Пестов В., 2006]. По данным С.Н. Хохрина [2004] величина энергетической кормовой единицы зерна ржи составляет 1,12, пшеницы - 1,20, ячменя $-1,15$, овса - 1,00. Однако Ш. Имангулов [2000] и T.М. Околелова [2001в] указывают на значительно меньшее значение данного показателя у зерна пшеницы - 238 ккал/100 г (или 1,01 ЭКЕ). В условиях Республики Башкортостан ЭКЕ зерна озимой ржи по нашим данным изменялась по годам и сортам от 1,13 до 1,16.

Энергетическая оценка является обобщающей и не отражает сбалансированность корма по отдельным питательным веществам. Отсутствие или недостаток в корме хотя бы одного из питательных веществ ухудшает использование корма, приводит к снижению продуктивности животного. Поэтому питательность зерна ржи определяется также содержанием в нем комплекса органических и минеральных веществ: протеин, жир, углеводы (клетчатка, сахара, крахмал), макро- и микроэлементы, витамины [Хазиахметов Ф.С., 2004].

В таблице 9 приведено сравнение питательной и энергетической ценности зерновых культур урожаев. 
Содержание питательных веществ и энергетическая ценность зерновых культур [LUFA Nord-West, Германия]

\begin{tabular}{|c|c|c|c|c|c|c|c|c|c|}
\hline Год & $\begin{array}{l}\text { Зерно- } \\
\text { вые }\end{array}$ & \begin{tabular}{|c|} 
Cухое \\
вещес- \\
тво, \% \\
\end{tabular} & $\begin{array}{c}\text { Сырой } \\
\text { белок, } \\
\% *\end{array}$ & $\begin{array}{c}\text { Сырой } \\
\text { жир, } \\
\text { \%* }\end{array}$ & $\begin{array}{l}\text { Клет- } \\
\text { чатка, } \\
\% \text { * }\end{array}$ & $\begin{array}{c}\text { Крах- } \\
\text { мал, } \\
\% *\end{array}$ & \begin{tabular}{|c|} 
МЕ \\
свиньи, \\
МДж/кг *
\end{tabular} & $\begin{array}{c}\mathrm{ME} \\
\text { КРС, } \\
\text { МДж/кг * }\end{array}$ & $\begin{array}{c}\text { NEL, } \\
\text { МДж/кг * }\end{array}$ \\
\hline \multirow{3}{*}{2009} & Рожь & 86,9 & 8,1 & 1,8 & 2,3 & 55,2 & 13,5 & 11,8 & 7,5 \\
\hline & \begin{tabular}{|l} 
Пше- \\
ница
\end{tabular} & 86,4 & 10,9 & 2,2 & 2,5 & 59,4 & 14,1 & 11,8 & 7,5 \\
\hline & $\begin{array}{l}\text { Яч- } \\
\text { мень }\end{array}$ & 86,3 & 10,6 & 2,8 & 5 & 51,6 & 12,9 & 11,3 & 7,1 \\
\hline \multirow{3}{*}{2010} & Рожь & 85,2 & 9,5 & 1,8 & 2,1 & 53,9 & 13,6 & 11,8 & 7,5 \\
\hline & \begin{tabular}{|l|} 
Пше- \\
ница
\end{tabular} & 85,7 & 11,9 & 2,1 & 2,6 & 58,1 & 14,1 & 11,8 & 7,5 \\
\hline & $\begin{array}{l}\text { Яч- } \\
\text { мень }\end{array}$ & 87,1 & 10,9 & 2,8 & 5,5 & 51,2 & 12,9 & 11,3 & 7,1 \\
\hline
\end{tabular}

*в расчете на $88 \%$ сухого вещества

\subsection{2. Содержание в зерне переваримого протеина и аминокислот}

С белками связаны все основные жизненные процессы организма. Они участвуют в образовании иммунных тел, передаче генетической информации, транспортировании веществ в организме, регулируют и катализируют биохимические реакции в процессе обмена веществ. Около $40 \%$ белковой массы продукта используется как источник энергии, а остальная часть - как пластический материал и биологически активные вещества [Зверев С.В., 2006].

Протеин корма необходим для построения белка тела молодых животных, возобновления изношенных тканей взрослых, образования белка молока у лактирующих животных, белка яиц у птиц-несушек, белка шерсти у овец. При недостатке протеина в кормовом рационе снижается количество гемоглобина в крови. Белковая недостаточность у животных вызывает различные заболевания.

У животных с однокамерным желудком протеин корма под влиянием протеолитических ферментов желудочного и кишечного соков переваривается до аминокислот, которые всасываются в кишечнике, поступают в воротную вену и через печень в общий круг кровообращения. У жвачных животных протеины съеденного корма в рубце частично расщепляются до аммиака, который используется микрофлорой рубца для синтеза микробного белка. Этот синтезируемый микробный белок вместе с протеином корма, оставшимся нерасщепленным, переваривается в последующих отделах пищеварительного тракта до аминокислот, которые и всасываются в кишечнике, попадая в кровь [Хохрин С.Н., 2004]. 
Использование для кормления сельскохозяйственных животных низкобелкового зерна влечет за собой повышенный расход кормов на создание единицы животноводческой продукции. По нормам кормления нужно, чтобы на каждую кормовую единицу приходилось не менее 100 г переваримого белка. Учитывая, что переваримость белков зерна в среднем составляет 70-90\%, для устранения дефицита кормового белка в зерне должно содержаться 14-15\% белковых веществ [Третьяков Н.Н., 2005].

В зерне озимой ржи содержится в среднем 13,4\% белка [Культурная флора ..., 1989]. В то же время, как показывают результаты многочисленных исследований, содержание белка в зерне колеблется в значительных пределах. В опытах I. Janicki [1963], E. Willegas, C. E McDonald, K. A. Gilles [1970], проведенных со 130 сортами озимой ржи в различных экологических условиях, содержание белка колебалось от 7,2 до $20,6 \%$, лизина - от 2,4 до 4,3\% [Культурная флора ..., 1989]. Нашими исследованиями [Бахтизин Н.Р., 1991; P.P. Исмагилов, Р.Б. Нурлыгаянов, Т.Н. Ванюшина, 2001] установлено изменение белковости зерна озимой ржи в зависимости от года, почвенноклиматических условий и сорта на территории Республики Башкортостан от 8,8 до $16,0 \%$.

Белковый комплекс, характерный для зрелых зерновок ржи, претерпевает очень сложные изменения в процессе формирования и налива зерна [Павлов А.Н., 1984]. Альбуминов и глобулинов, как правило, всегда содержится больше в первые фазы созревания зерна, а затем количество их снижается. Содержание высокомолекулярных белков - глиадинов и глютенинов, наоборот, в начале формирования зерна незначительно, но, начиная с фазы молочной спелости, происходит усиленный синтез, причем синтез глютенинов заканчивается раныше, чем глиадинов, накопление которых идет до конца полной спелости зерна [Приезжева Л.Г., 1970а; Приезжева Л.Г., 1971].

Рожь отличается от пшеницы, ячменя и других зерновых культур сравнительно большим содержанием в зерне водо- и солерастворимых белков (альбумины, глобулины), которые имеют повышенное содержание незаменимой аминокислоты лизина [Miller D.F., 1958]. Поэтому считают, что белок ржи обладает большей биологической ценностью, чем белок пшеницы и других зерновых культур [Культурная флора ..., 1989; Кедрова Л.И., 2000, 2003].

Биологическая ценность белка ржи на 2 единицы выше, чем пшеницы 58 против 56 [Солошенко В.А., 1998]. Рожь уступает пшенице по содержанию сырого протеина и аминокислоты метионина, но содержит больше аминокислоты лизина и меньше клетчатки [Околелова Т.М., 2001б; Коробов А.П., 2003; Андрианова Е.К., 2003; Борос Д., 2003]. По данным Хохрина С.Н. [2004] в 1 кг зерна ржи содержится лизина 4,3 г, пшеницы - 3,9, ячменя - 4,1 и овса $-3,6$ г (таблица 10).

Роль отдельных аминокислот в кормлении животных неоднозначна. Часть аминокислот (незаменимые) не может синтезироваться в организме животных и должна поступать с кормами: лизин, метионин, триптофан, гистидин, лейцин, изолейцин, треонин, валин, аргинин и фенилаланин. 
Аминокислоты - серин, пролин, аспаргиновая кислота, глицин, глутаминовая кислота, аланин, цистин, тирозин и другие синтезируются в организме животных из азотсодержащих соединений. Важное значение имеют критические аминокислоты - лизин, метионин и триптофан [Хохрин С.Н., 2004; Методические рекомендации..., 1983; Куватов Д.М., 2003].

Таблица 10

Энергетическая и белковая питательность 1 кг зерна [Хохрин С.Н., 2004]

\begin{tabular}{|c|c|c|c|c|}
\hline Показатель & Пшеница & Рожь & Ячмень & Овес \\
\hline $\begin{array}{l}\text { Энергетическая кормовая единица } \\
\text { (ЭКЕ) }\end{array}$ & 1,20 & 1,12 & 1,15 & 1,00 \\
\hline Обменная энергия, МДж & 12,0 & 11,2 & 11,5 & 10,0 \\
\hline $\begin{array}{l}\text { Содержание, г: } \\
\text { сухого вещества (СВ) } \\
\text { сырого протеина (СП) } \\
\text { переваримого протеина (ПП) }\end{array}$ & $\begin{array}{l}852 \\
149 \\
120 \\
\end{array}$ & $\begin{array}{c}845 \\
120 \\
91\end{array}$ & $\begin{array}{c}833 \\
113 \\
85 \\
\end{array}$ & $\begin{array}{c}860 \\
108 \\
79 \\
\end{array}$ \\
\hline $\begin{array}{l}\text { Аминокислоты, г: } \\
\text { лизин } \\
\text { метионин+цистин } \\
\text { триптофан } \\
\text { валин } \\
\text { изолейцин } \\
\text { лейцин } \\
\text { треонин } \\
\text { фенилаланин }\end{array}$ & $\begin{array}{l}3,9 \\
4,1 \\
1,4 \\
4,6 \\
3,4 \\
6,9 \\
2,6 \\
4,3\end{array}$ & $\begin{array}{l}4,3 \\
3,5 \\
1,2 \\
5,3 \\
3,5 \\
7,5 \\
3,2 \\
5,2\end{array}$ & $\begin{array}{l}4,1 \\
3,6 \\
1,8 \\
5,4 \\
3,5 \\
7,2 \\
2,9 \\
5,1\end{array}$ & $\begin{array}{l}3,6 \\
3,2 \\
1,1 \\
5,3 \\
3,9 \\
7,4 \\
3,3 \\
5,3\end{array}$ \\
\hline
\end{tabular}

Лизин в организме животных участвует в синтезе тканевых белков, способствует образованию протеина, росту и развитию костной системы, а также инициирует деление клеток [Томмэ М.Ф., 1972; Яхин А., 2000; Куватов Д.М., 2003], входит в состав ферментов, что во многом повышает переваримость кормов [Куватов Д.М., 2003].

Триптофан участвует в обновлении белков плазмы крови, является основным фактором регуляции жирового обмена, особенно печени.

Аргинин в организме животных является катализатором синтеза мочевины, креатина мышц и инсулина.

Гистидин участвует в энергетическом обмене организма, в синтезе гемоглобина и эритроцитов крови.

Ароматические аминокислоты - фенилаланин и тирозин играют равноценную роль в обмене веществ. Они вместе с триптофаном определяют физиологическую активность ферментов пищеварительного тракта, окислительных ферментов в клетках, а также многих гормонов.

Серосодержащие аминокислоты - метионин, цистин и цистеин являются в обмене веществ частично взаимозаменяемыми. Метионин участвует в процессах переаминирования, что приводит к образованию новых 
соединений: холина, креатина, адреналина, ниацина и др. Цистин активирует инсулин. При отсутствии или недостатке незаменимых аминокислот у молодых животных задерживается или совсем прекращается рост, у взрослых животных ухудшается общее состояние здоровья, снижается продуктивность [Калашников А.П., 2003; Хохрин С.Н., 2004].

Только достаточный набор незаменимых аминокислот обеспечивает формирование новых и восстановление отмирающих клеток организма, особенно мышечной ткани [Куватов Д.М., 2003]. Обеспечение животных незаменимыми аминокислотами позволяет устранить специфические нарушения обмена веществ, вызываемые недостатком отдельных аминокислот [Томмэ М.Ф., 1972]. Все аминокислоты в значительной мере растворимы в воде и поэтому хорошо усваиваются животными [Мотовилов К.Я., 2004].

Во Всесоюзном научно-исследовательском институте зерна и продуктов его переработки изучали аминокислотный состав ржи и обнаружили, что различные сорта озимой ржи значительно отличаются по своим биохимическим свойствам даже при выращивании в одинаковых почвенно-климатических условиях. Аминокислотный состав зерна ржи по сортам имеет большие различия, особенно в содержании тирозина, пролина, гистидина и метионина [Томмэ М.Ф., 1972].

\subsection{3. Содержание в зерне углеводов и жира}

Углеводы включает моносахариды (простые сахара) и полисахариды (сложные углеводы). Полисахариды, в свою очередь, подразделяются на две группы: полисахариды первого порядка (сложные сахара) и полисахариды второго порядка (высокомолекулярные углеводы) [Гуняженко И.В., 1985; Щербаков В.Г., 2003; Хохрин С.Н., 2004; Зверев С.В., 2006]. В таблице 11 приводится классификация углеводов, предложенная С.В. Зверевым [2006].

Таблица 11

Классификация углеводов [Зверев С.В., 2006]

\begin{tabular}{|c|c|c|c|}
\hline \multicolumn{4}{|c|}{ Углеводы зерна } \\
\hline \multicolumn{2}{|c|}{$\begin{array}{c}\text { Моносахариды } \\
\text { (простые сахара) }\end{array}$} & \multicolumn{2}{|c|}{$\begin{array}{c}\text { Полисахариды } \\
\text { (сложные углеводы) }\end{array}$} \\
\hline Пентозы & Гексозы & $\begin{array}{c}\text { Полисахариды } \\
\text { 1-го порядка } \\
\text { (олигосахариды) }\end{array}$ & $\begin{array}{c}\text { Полисахариды } \\
\text { 2-го порядка }\end{array}$ \\
\hline $\begin{array}{c}\text { арабиноза } \\
\text { ксилоза } \\
\text { рибоза } \\
\text { манноза }\end{array}$ & $\begin{array}{r}\text { глюкоза } \\
\text { фруктоза } \\
\text { галактоза }\end{array}$ & $\begin{array}{c}\text { Дисахариды: } \\
\text { сахароза, мальтоза, } \\
\text { лактоза, целлобтоза } \\
\text { Трисахариды: } \\
\text { раффиноза }\end{array}$ & $\begin{array}{c}\text { крахмал, клетчатка, } \\
\text { декстрин, инулин, } \\
\text { пектины, гемицеллюлозы, } \\
\text { пентозаны, слизи, камеди }\end{array}$ \\
\hline
\end{tabular}


По превращениям в пищеварительном тракте животных углеводы кормов делятся на легкоусвояемые, к которым относятся все моносахариды и дисахариды, а из полисахаридов - крахмал, и трудноусвояемые - все полисахариды, кроме крахмала [Хохрин С.Н., 2004].

Углеводы зерновых не однородны по своему составу, так как объединяют сахара, декстрины, крахмал, целлюлозу, гемицеллилозу и лигнин в различных соотношениях. Поэтому основные зерновые корма (пшеница, рожь, ячмень, овес, кукуруза), имея почти одинаковое суммарное количество углеводов (80$85 \%$ ), но в различном количественном и качественном соотношении, имеют и различную степень переваримости и использования в организме животных [Имангулов Ш., 2000; Околелова Т.М., 2001в].

В зерне ржи моносахариды, дисахариды и трисахариды в основном сконцентрированы в зародыше зерновки. В зародыше зерновки ржи содержится 1,6-2,3\% сахаров, которые представлены сахарозой, раффинозой и очень малым количеством глюкозы и фруктозы [Кретович В.Л., 1991].

Микроорганизмы рубца расщепляют сложные углеводы до простых сахаров, которые в дальнейшем сбраживаются до уксусной (50-70\%), пропионовой (17-21\%), масляной (14-20\%), а также валериановой и муравьиной кислот, метана и углекислого газа [Куватов Д.М., 2003; Калашников А.П., 2003]. Образующиеся в рубце в большом количестве летучие жирные кислоты составляют у жвачных главный источник энергии. Летучие жирные кислоты всасываются в рубце. Если в рационе много грубых кормов, богатых клетчаткой, то в рубце повышается содержание уксусной кислоты. Корма, богатые крахмалом и особенно сахаром, способствуют образованию пропионовой кислоты. При концентратном типе кормления в рубце возрастает количество масляной кислоты.

Не переварившаяся в рубце часть углеводов переваривается в тонком кишечнике, где на пищевые массы изливаются соки поджелудочной железы. Содержащиеся в них ферменты (амилаза, мальтаза, инвертаза, лактаза) переводят сложные углеводы в моносахариды, которые и всасываются из кишечника в кровеносные сосуды.

Полисахариды (сложные углеводы), многочисленная и широко распространенная группа органических соединений, наряду с белками и жирами необходимы для жизнедеятельности животных и растительных организмов. Они являются одним из основных источников энергии, образующейся в результате обмена веществ организма [Плешков Б.П., 1980, 1987].

Значительную долю углеводов и в том числе полисахаридов в зерне ржи составляет крахмал. Крахмал - основной запасной углевод зерновки злаков [Кедрова Л.И., 1996; Третьяков Н.Н., 2005]. Количество крахмала, в зависимости от сорта и условий выращивания, может изменяться в широких пределах и в среднем составляет 51,8\% массы эндосперма [Голенков В.Ф., 1964; Кретович В.Л., 1991; Щербаков В.Г., 2003; Хохрин С. Н., 2004]. Содержание крахмала в зерне приведено в таблице 12. 
В зерне запасной крахмал откладывается в основном в мучнистой части эндосперма в виде крахмальных зерен (гранул) [Третьяков Н.Н., 2005; Плешков Б.П., 1980, 1987], а в пленках, оболочках, алейроновом слое и зародыше содержится очень мало [Плешков Б.П., 1980, 1987]. Каждая крахмальная гранула представляет собой сферокристалл, шарообразное скопление тончайших игольчатых кристаллов, радиально расположенных от центра зерна к его периферии. Крахмальные гранулы ржи крупнее, чем других культур, и их размер варьирует от 0,002 до 0,12 мм.

Таблица 12

Содержание углеводов и жира в 1 кг зерна (Хохрин С.Н., 2004)

\begin{tabular}{|l|c|c|c|c|}
\hline \multicolumn{1}{|c|}{ Показатель } & Пшеница & Рожь & Ячмень & Овес \\
\hline Содержание, Г: & & & & \\
сырого жира (СЖ) & 15,0 & 19,0 & 22,0 & 40,0 \\
сырой клетчатки (СК) & 28,0 & 21,0 & 49,0 & 97,0 \\
\hline НДК* & 157 & 118 & 168 & 543 \\
\hline БЭВ & 642 & 672 & 638 & 573 \\
\hline Сахаров & 15,0 & 15,0 & 20,0 & 25,0 \\
\hline Крахмала & 490 & 518 & 485 & 320 \\
\hline
\end{tabular}

НДК - нейтрально-детергентная клетчатка. Это фракиия корма, которая не растворяется в нейтральном детергенте (отмывающие синтетические химические средства). Показывает количество клеточного материала стенок растений или структурных волокон в корме. Чем меньше НДК в корме, тем больще животное поедает грубого (фуражного) корма, поэтому желательно в корме низкое содержание НДК.

Углеводная часть крахмала на 96,1-97,6\% состоит из двух полисахаридов: амилозы и амилопектина [Кретович В.И., 1980; Щербаков В.Г., 2003], от концентрации которых зависят коллоидные свойства крахмала. В среднем доля амилозы в крахмале обычно варьирует в пределах 15-25\%, а амилопектина 75-85\% [Цитович И.К., 1974; Плешков Б.П., 1980, 1987; Третьяков Н.Н., 2005]. Амилопектин имеет сильно разветвленную цепь глюкозных остатков, образует клейстер, амилоза имеет малоразветвленную цепь глюкозных остатков [Цитович И.К., 1974], хорошо растворим в воде [Щербаков В.Г., 2003] и образует коллоидный раствор (но не клейстер) [Цитович И.К., 1974; Гуняженко И.В., 1985].

Крахмал гидролизуется как под действием кислот (при нагревании), так и под действием ферментов: у животных - птиалина слюны. Наряду с отдельными моносахаридами (глюкоза, фруктоза) и дисахаридами (сахароза, мальтоза, лактоза), крахмал корма сравнительно хорошо переваривается животными [Кошелева Г., 1999]. Гидролизуется крахмал с образованием более простых углеводов: сначала декстрины (амилодекстрины, эритродекстрины, арходекстрины), дальше образуется мальтоза, которая разлагается до глюкозы [Цитович И.К., 1974; Костин В.И., 2001]. 
По соотношению главных компонентов, амилозы и амилопектина, различают три основных типа крахмала: восковидный (клеющий), состоящий преимущественно из амилопектина и содержащийся в зерне ячменя, сорго и ржи; обычный, имеющий приблизительно 50\% амилозы и содержащийся в зерне пшеницы и риса, картофеле; высокоамилозный, содержащий свыше 50\% амилозы - это сладкие сорта гороха и кукурузы [Meyer К.Н., 1940; Alexander D., 1970]. Способность крахмала к перевариванию зависит не только от соотношения главных компонентов крахмальной гранулы, но и от его способности набуханию, степени полимеризации и кристаллизации, а также наличия поврежденных крахмальных гранул, образующихся в результате размола зерна [Stevens J., 1972; Friedrich W., 1975; Околелова Т.М., 2001в].

Клетчатка (целлюлоза) - полисахарид 2-го порядка, основная часть оболочек растительных клеток. Содержится в растениях не в чистом виде, а вместе с инкрустирующими веществами (лигнином, пектиновыми веществами, смолами, липидами) [Цитович И.К., 1974; Гуняженко И.В., 1985].

Целлюлоза представляет собой линейный полимер из остатков бетаглюкозы, связанных гликозидными бета-связями. Степень полимеризации изменяется в широких пределах от нескольких десятков до 7-10 тыс. глюкозных остатков в молекуле. В отличие от $\alpha$-глюкозы (крахмал), $\beta$ конфигурация допускает образование между цепями поперечных связей, расположенных в двух направлениях. Благодаря этому молекулы целлюлозы агрегированы в микрофибриллы, имеющие высокоупорядоченную жесткую, прочную, кристаллическую структуру, что обусловливает ее устойчивость к действию щелочей и кислот. При гидролизе целлюлозы образуется целлобиоза, которая в дальнейшем распадается до глюкозы [Имшенецкий А.А., 1953; Цыперович A.C., 1971; Stevens J., 1972; Theander O., 1977; Использование питательных..., 1978; Кретович В.Л.,1991; Кошелева Г., 1999; Черкасова С., 2001].

Клетчатка не разрушается ферментами пищеварительного тракта и то ее количество, которое в период нахождения пищевых масс в рубце не подверглось воздействию микроорганизмов, в дальнейшем не используется животными и выделяется в виде непереваренных остатков с калом. Переваримость клетчатки зависит от количества и активности целлюлозолитических микроорганизмов в рубце. При скармливании животным кормов с большим количеством клетчатки количество целлюлозолитических микроорганизмов в рубце увеличивается [Калашников А.П., 2003]. Организм жвачных животных находится в состоянии симбиоза с целлюлозолитическими микроорганизмами, и это позволяет переваривать корма, содержащие большое количество клетчатки. Рубец крупного рогатого скота - сложная экосистема, населенная бактериями, простейшими грибами и бактериофагами. Некоторые из них участвуют в расщеплении клетчатки [Эрнст Л., 2006].

Избыточное содержание клетчатки в рационе снижает переваримость и эффективность использования животными питательных веществ. Однако в определенном количестве она необходима как фактор, нормализующий пищеварение в рубце [Калашников А.П., 2003]. Основное ее физиологическое 
назначение - связывать воду [Зверев С.В., 2006]. Клетчатка участвует в различных важных функциях организма, механически воздействует на нервномышечный аппарат кишечника, стимулирует моторную функцию органов пищеварения, усиливает выделение необходимых для пищеварения соков, придает пористость пищевым массам, обеспечивает доступ к ним пищевых соков. Клетчатка улучшает обмен веществ, нормализует рост в кишечнике гнилостных микробов, способствует выведению из организма излишнего количества холестерина и продуктов распада [Щербаков В.Г., 2003].

Среднее содержание сырой клетчатки в зерне ржи $-2,1 \%$, пшеницы $-2,8$, ячменя $-4,9$ и овса $-9,7 \%$ (таблица 12). Клетчатка входит, главным образом, в состав плодовой и семенной оболочек и клеточных стенок. Из общего количества клетчатки в плодовой оболочке зерна ржи сорта Вятка московская содержится 58,3\%, в семенной оболочке - 22,7, в алейроновом слое - $11 \%$, в зародыше - 3,4 и в эндосперме - 4,6\% [Плешков Б.П., 1980, 1987].

Пектин - полисахарид 2-го порядка, входит в состав межклеточного склеивающего вещества. Пектин состоят из полиуроновых кислот и нейтральных сахаров и представляют собой гелеобразные аморфные вещества. Строение молекул пектинов определяет их уникальное свойства структурообразователей гелей [Смирнов В.И., 1971; Кошелева Г., 1999].

Важное свойство пектиновых веществ - способность их к желированию, т.е. образовыванию прочных студней в присутствии большого количества сахара (65-70\%). В образующемся студне массовая доля пектина составляет от 0,2 до 1,5\% [Кирилов М., 2001; Щербаков В.Г., 2003].

Пектиновые вещества состоят в основном из остатков галактуроновой кислоты, которые образуют длинную молекулярную цепь. В зависимости от степени этерификации пектин может быть высоко- и низкоэтерифицированным, т. е. представляет собой частично или полностью метоксилированную кислоту. В растениях пектины присутствуют в виде нерастворимого протопектина, связанного с арабаном или ксиланом клеточной стенки. Из протопектина под действием фермента протопектиназы или разбавленных кислот образуется растворимый пектин, состоящий из частично метоксилированных остатков полигалактуроновой кислоты. При щелочном или ферментативном гидролизе растворимый пектин легко теряет почти все метоксильные группы и превращается в свободную пектиновую кислоту, которая практически нерастворима в воде и не способна давать студни в присутствии сахара. Растворимость пектина зависит от степени полимеризации (размера молекулы) и этерификации. Пектин с меньшей молекулярной массой (короткой цепью) и большим количеством метоксильных групп растворяется легче.

Пектин обладает важными биологическими свойствами, которые обусловлены наличием свободных карбоксильных групп галактуроновой кислоты, способных связывать тяжелые металлы, в том числе радионуклиды, с образованием нерастворимых комплексов, которые выводятся из организма.

Общебиологическая активность пектинов (их влияние на функциональное состояние организма, обмен веществ, способность связывать желчные кислоты, стероиды, токсины и другие вещества суточного рациона) в значительной мере 
зависит от состава и свойств пектиновых веществ: их молекулярной массы, степени этерификации [Технология консервирования ..., 1993].

Пектиновые, студенистые вещества растений связывают стронций и кобальт, включая и радиоактивные изотопы. Большая часть пектина не переваривается и удаляется из организма вместе с вредными веществами. Пектины улучшают пищеварение, снижают интенсификацию гнилостных процессов в кишечнике, обезвреживают ядовитые вещества и тем самым улучшают условия выработки в кишечнике необходимых для организма веществ, в частности витаминов группы В. Пектины способствуют росту и жизнедеятельности полезных бактерий, освобождению в организме ядовитых веществ и выведению из организма излишнего количества холестерина [Технология консервирования..., 1993]. В зерне ржи содержится пектина 7-8,5\% от безазотистых экстрактивных веществ [Фицев А.И., 2007].

Жиры обладают высокой энергетической ценностью: 1 г жира при окислении в организме дает 37,7 кДж энергии. Поэтому жир в кормах источник энергии для животных. Жиры обеспечивают в среднем $33 \%$ суточной энергоценности рациона, входят в состав клеток и клеточных структур, участвуют в обменных процессах организма.

По общему содержанию жира зерно ржи мало отличается от других зерновых культур, за исключением овса (таблица 12). В больших концентрациях липиды находятся в зародыше (до 15\% на сухую массу зародыша) [Культурная флора ..., 1989].

В среднем содержание жира в зерне ржи составляет 1,5-1,9\%.(Хохрин C.Н., 2004, Калашников А.П., 2003). В условиях Республики Башкортостан содержание жира в зерне ржи было несколько выше средних данных и изменялось незначительно - от 2,10\% до 2,13\% [Исмагилов Р.P., Ахиярова Л.М., 2008].

В составе безазотистых экстрактивных веществ (БЭВ) преобладают крахмал и сахар, сюда также входят органические кислоты (щавелевая, яблочная, молочная, уксусная, масляная), инулин, пектиновые вещества, часть гемицеллюлоз и другие вещества [Калашников А.П., 2003; Хохрин С.Н., 2004]. Безазотистые экстрактивные вещества, в особенности сахара и крахмал, являются не только питательными веществами для животного, они служат также пищей для населяющих преджелудки жвачных микроорганизмов и используются ими для синтеза бактериального белка [Плешков Б.П., 1980, 1987; Калашников А.П., 2003]. Наибольшим содержанием БЭВ отличается зерно ржи - 672 г/кг зерна, в пшенице - 642, в ячмене 638 , в овсе -573 г/кг зерна [Хохрин С.Н., 2004].

\subsection{4. Содержание минеральных веществ в зерне озимой ржи}

В питании сельскохозяйственных животных значение минеральных веществ чрезвычайно велико. Объясняется это той большой ролью, которую минеральные вещества играют во всех процессах обмена веществ, происходящих в организме. Минеральную питательность кормов 
характеризуют следующие показатели: содержание сырой и чистой золы; наличие в золе макро- и микроэлементов; соотношение отдельных элементов кальция и фосфора, натрия и калия, кальция и цинка и др.; кислотно-щелочное соотношение. Из макроэлементов наибольшее значение в кормлении животных имеют кальций, фосфор, калий, натрий, хлор, магний, сера; из микроэлементов - кобальт, йод, марганец, цинк, железо, медь. Недостаток макро- и микроэлементов приводит к нарушению минерального обмена и резкому снижению продуктивности животных [Диагностика и профилактика ..., 2005].

Кальций в организме служит основным материалом для построения костной ткани, он входит в состав всех клеток организма, участвует в регулировании реакции крови, возбудимости мышечной и нервной тканей, свертывания крови. Длительный недостаток кальция в рационе животных приводит к хрупкости и ломкости костей. В зерне ржи кальция содержится 0,9 г/кг зерна, что больше чем в зерне пшеницы $(0,7$ г), но меньше чем в зерне ячменя $(2,0$ г) и овса $(1,5$ г) (таблица 13$)$.

Фосфор, также как и кальций, составляет основу костной ткани. Много фосфора в железистой ткани, мышцах, нервной ткани. Фосфор необходим для нормальной деятельности микроорганизмов, населяющих преджелудки жвачных: азотобактер использует фосфор для построения нуклеопротеидов. Недостаток кальция и фосфора в кормах, а также неправильное их соотношение в рационах приводит к рахиту, остеопорозу и остеофиброзу [Калашников А.П., 2003]. Наибольшим содержанием фосфора отличается зерно пшеницы (4,3 г/кг зерна), наименьшим - зерно ржи (2,8 г/кг).

Калий в организме содержится в большом количестве во всех тканях, кроме костной и хрящевой [Калашников А.П., 2003]. При недостатке калия в кормах животные плохо растут, у них появляется извращенный аппетит и повышенная возбудимость, нарушается функция печени, почек, наблюдается расстройство сердечной деятельности [Хохрин С.Н., 2004]. Содержание калия в зерне пшеницы и ржи несколько меньше, чем в зерне ячменя и овса (соответственно 4,6 и 4,8 г; 5,0 и 5,4 г/кг зерна).

Таблица 13

Содержание макро- и микроэлементов в 1 кг зерна [Хохрин С.Н., 2004)

\begin{tabular}{|l|c|c|c|c|}
\hline \multicolumn{1}{|c|}{ Показатель } & Пшеница & Рожь & Ячмень & Овес \\
\hline Макроэлементы, г: & & & & \\
кальций & 0,7 & 0,9 & 2,0 & 1,5 \\
фосфор & 4,3 & 2,8 & 3,9 & 3,4 \\
магний & 1,1 & 1,1 & 1,0 & 1,2 \\
калий & 4,6 & 4,8 & 5,0 & 5,4 \\
сера & 1,6 & 0,9 & 1,3 & 1,3 \\
\hline
\end{tabular}




\begin{tabular}{|l|c|c|c|c|}
\hline Микроэлементы, мг: & & & & \\
железо & 50,0 & 63,0 & 50,0 & 41,0 \\
медь & 2,3 & 6,7 & 4,2 & 4,9 \\
цинк & 40,0 & 20,0 & 35,0 & 22,0 \\
марганец & 41,0 & 30,0 & 14,0 & 56,0 \\
кобальт & 0,03 & 0,07 & 0,26 & 0,07 \\
йод & 0,11 & 0,09 & 0,22 & 0,10 \\
\hline
\end{tabular}

Натрий в крови и тканевых жидкостях участвует в нейтрализации кислот. Хлористый натрий является материалом для образования желудочного сока. При недостатке натрия пропадает аппетит, снижается синтез жира и протеина, задерживается рост у молодых животных [Калашников А.П., 2003].

Хлор в организме находится в крови, коже и подкожной клетчатке, лимфе и желудочном соке. В кормах хлора мало. Вместе с натрием он поступает в организм в составе поваренной соли ([Калашников А.П., 2003]. Исключительную роль хлор играет в пищеварении, так как входит в состав желудочного сока в виде соляной кислоты. Недостаток хлора в рационах вызывает понижение секреции соляной кислоты, что ведет к нарушению пищеварения [Хохрин С.Н., 2004].

Магний жизненно необходим организму, но так как корма обычно содержат достаточно магния, животные не испытывают в нем недостатка. Содержание магния в зерне злаков примерно на одном уровне (от 1,0 до 1,2 г/кг зерна).

Сера входит в состав глютатиона, играющего важную роль в окислительных процессах организма, инсулина - гормона поджелудочной железы и других веществ. Сера в организм поступает в составе органических соединений, например, с аминокислотами цистином и метионином [Калашников А.П., 2003]. Большая часть серы сосредоточена в волосяном покрове, роговом башмаке, коже (Хохрин С.Н., 2004). Наибольшее содержание серы в зерне пшеницы (1,6 г/кг), затем ячменя и овса (по 1,3 г/кг), меньше всего в зерне ржи $(0,9$ г/кг).

Микроэлементы в организме животных играют важную роль, и их недостаток приводит к микроэлементозу [Микроэлементозы сельскохозяйственных ..., 1967].

Железо необходимо животным как составная часть гемоглобина крови. При недостатке его развивается анемия. Содержание железа в зерне ржи 63 мг, пшеницы и ячменя 50 мг и овса 41 мг/кг зерна (таблица 13).

Медь участвует в процессах кроветворения в качестве биокатализатора, стимулирующего образование гемоглобина из неорганических соединений железа, хотя она и не входит в состав гемоглобина. Оказывает положительное влияние на устойчивость организма к заболеваниям. При недостатке меди в кормах у животных усугубляется анемия. Наибольшее содержание меди в зерне ржи (6,7 мг/кг), примерно одинаковое содержание в зерне ячменя и овса (соответственно 4,2 и 4,9 мг/кг), меньше всего содержится меди в зерне пшеницы $(2,3$ мг/кг). 
Кобальт входит в состав витамина $\mathrm{B}_{12}$, он активирует гидролитические ферменты, увеличивает синтез нуклеиновых кислот и мышечных белков. При недостатке в корме кобальта у крупного рогатого скота и овец появляется акобальтоз. Кобальта в зерне примерно одинаковое содержание, за исключением ячменя.

Йод входит в состав гормонов щитовидной железы, участвует в образовании гормона тироксина. Тироксин контролирует состояние энергетического обмена в организме животных. При ее недостатке нарушается функция щитовидной железы. Она увеличивается в размерах и образуется эндемический зоб, нарушается функция размножения [Хохрин С.Н., 2004]. Больше йода содержится в зерне ячменя - 0,22 мг/кг зерна, меньше в зерне пшеницы - 0,11 мг, примерно одинаковое содержание его в зерне овса и ржи, соответственно, 0,1 и 0,09 мг/кг зерна (таблица 13).

Марганец оказывает благоприятное влияние на рост молодняка. При его недостатке развивается хромота. Играет значительную роль в процессах размножения животных [Калашников А.П., 2003]. В зерне пшеницы марганца содержится больше (41 мг/кг), чем в зерне ржи (30 мг/кг) и ячменя (14 мг/кг), но меньше, чем в зерне овса (56 мг/кг).

Цинк сосредоточен главным образом в костях и коже животных. Он необходим для нормального роста, развития, поддержания репродуктивной функции (размножения), вкуса и обоняния, нормального заживления ран и др. Недостаток цинка угнетает рост, понижает плодовитость и может привести к бесплодию [Хохрин С.Н., 2004]. Примерно одинаковое содержание цинка в зерне ржи и овса (соответственно 20 и 22 мг/кг), в зерне пшеницы больше (40 мг/кг), чем в зерне ячменя (35 мг/кг зерна).

Сырая зола характеризует общее содержание всех минеральных составных частей корма и представляет собой несгораемый остаток сухого вещества. Остаток сухого вещества, свободный от диоксида углерода, угля и песка, называется чистой золой [Хохрин С.Н., 2004]. Зерно ржи состоит из 1,7$2,3 \%$ минеральных веществ (пшеницы $-1,6 \%$, ячменя $-1,7 \%$, овса $-2,6 \%$ в среднем) (Исмагилов Р.Р., 2001). Зола в зерне распределена неравномерно. При определении количества золы в отдельных частях зерна ржи были получены следующие средние данные (\% сухой массы): целое зерно - 1,82, плодовые оболочки $-3,54$, семенные оболочки $-2,89$, алейроновый слой $-7,97$, зародыш - 5,30, эндосперм - 0,42 [Плешков Б.П., 1980, 1987]. Содержание золы особенно высоко в алейроновом слое ржи в основном вследствие присутствия в клетках данного слоя алейроновых тел, состоящих из гранул фитина - смеси солей калия и магния миоинозитола гексафосфата [Salmon J., 1940; Pomeranz Y., 1963; Jacobsen J.V., 1971], окружающих белково-содержащую оболочку [Lui N.S., 1967]. Зола зерна ржи, как и других мятликовых, состоит, главным образом, из фосфорнокислых солей калия, магния и кальция (Культурная флора ..., 1989].

\subsection{5. Содержание витаминов}


Витамины - вещества, обладающие высокой биологической активностью в малых дозах, необходимые для жизнедеятельности организма [Хохрин С.Н., 2004]. Наличие витаминов в рационе способствует лучшему использованию питательных веществ. При отсутствии или длительном недостатке витаминов в рационах у животных возникают заболевания, называемые авитаминозами. Все витамины без исключения нужны животному для нормального обмена веществ [Калашников А.П., 2003].

Особенно много в зерне семейства мятликовых витаминов группы $\mathrm{B}$, а главный источник витамина В $\mathbf{B}_{1}$ - это зерновые культуры [Плешков Б.П., 1980, 1987]. В этой группе различают более 10 отдельных витаминов. Большинство витаминов группы В животные синтезировать сами не могут [Калашников А.П., 2003].

Недостаток витамина $\mathrm{B}_{1}$ (тиамин) вызывает у животных потерю аппетита, расстройство пищеварения, а затем отрицательные изменения в нервной системе [Калашников А.П., 2003]. Содержание витамина $\mathrm{B}_{1}$ по данным С.Н. Хохрина [2004] в зерне ржи составляет 4,1 мг/г, что несколько выше содержания данного витамина в зерне пшеницы и ячменя. Витамин $\mathrm{B}_{1}$ распределен в зерновке неравномерно (таблица 14). Наибольшее его количество (в 25-30 раз больше, чем в целом зерне) находится в щитке и прилегающих к нему клетках эндосперма, много его и в зародыше, оболочках над зародышем, а также в алейроновом слое; в мучнистой части эндосперма этого витамина в 5-6 раз меньше, чем в целом зерне [Плешков Б.П., 1980, 1987].

Таблица 14

Распределение витамина $\mathrm{B}_{1}$ (тиамина) в зародыше и щитке зерновки

\begin{tabular}{|l|c|c|c|c|}
\hline \multirow{2}{*}{ Культура } & \multicolumn{2}{|c|}{ Содержание ткани в зерновке, } & \multicolumn{2}{c|}{ Содержание тиамина в } \\
& \multicolumn{2}{|c|}{$\%$} & \multicolumn{2}{c|}{ ткани, \% } \\
\cline { 2 - 5 } & зародыш & щиток & зародыш & щиток \\
\hline Рожь & 1,80 & 1,73 & 5,0 & 82,0 \\
\hline Пшеница & 1,20 & 1,54 & 3,0 & 59,0 \\
\hline Ячмень & 1,85 & 1,53 & 8,0 & 49,0 \\
\hline Овес & 1,60 & 2,13 & 4,5 & 28,0 \\
\hline
\end{tabular}

Витамин В 2 (рибофлавин) участвует в белковом, жировом и нуклеинокислотном обмене веществ [Куватов Д.М., 2003]. При его недостатке возникают дерматиты, поносы, параличи и катаракты [Калашников А.П., 2003]. Витамин $\mathrm{B}_{2}$ по данным С.Н. Хохрина [2004] в зерне ржи содержится 1,8 мг/г, что выше содержания данного витамина в зерне пшеницы, овса и ячменя (таблица 15). Распределение Витамина $\mathrm{B}_{2}$ по отдельным частям зерновки примерно такое же, как и витамина В 1 [Плешков Б.П., 1980, 1987].

Витамин $\mathbf{B}_{3}$ (пантотеновая кислота) стимулирует развитие микроорганизмов, входит в ферментные системы. Недостаток его вызывает патологические изменения в центральной нервной системе (Калашников А.П., 2003]. Содержание витамина $B_{3}$ в зерне ржи составляет 8,0 мг/г, что ниже 
содержания данного витамина в зерне других зерновых злаковых культур (таблица 15). Витамина $\mathrm{B}_{3}$ в эндосперме зерновки обычно в 2-4 раза меньше, чем в зародыше и алейроновом слое [Плешков Б.П., 1980, 1987].

Таблица 15

Содержание витаминов в 1 кг зерна [Хохрин С.Н., 2004)

\begin{tabular}{|l|c|c|c|c|}
\hline \multicolumn{1}{|c|}{ Показатель } & Пшеница & Рожь & Ячмень & Овес \\
\hline Витамины, мг: & & & & \\
$\mathrm{E}$ & 13,0 & 15,0 & 50,0 & 13,0 \\
$\mathrm{~B}_{1}$ & 3,9 & 4,1 & 3,5 & 7,3 \\
$\mathrm{~B}_{2}$ & 1,1 & 1,8 & 1,1 & 1,1 \\
$\mathrm{~B}_{3}$ & 13,0 & 8,0 & 9,0 & 13,0 \\
$\mathrm{~B}_{4}$ & 1014 & 450 & 1100 & 900 \\
$\mathrm{~B}_{5}$ & 53,0 & 13,0 & 60,0 & 13,0 \\
$\mathrm{~B}_{6}$ & 5,0 & 2,7 & 3,1 & 1,9 \\
\hline Каротин, мг & 10,0 & 2,0 & 0,5 & 1,0 \\
\hline
\end{tabular}

Витамин $\mathbf{B}_{4}$ (холин) служит в основном в качестве донора метиленовых групп $\left(\mathrm{CH}_{3}\right)$, которые необходимы для создания креатина и адреналина, а также для жирового обмена и других обменных процессов [Куватов Д.М., 2003]. Содержание витамина $\mathrm{B}_{4}$ по данным С.Н. Хохрина [2004] в зерне ржи составляет 450 мг/г (таблица 15).

Витамин В В $_{5}$ РP - никотиновая кислота) играет важную роль в окислительных процессах в тканях [Калашников А.П., 2003]. Нехватка его приводит к нарушениям образования глюкозы и других процессов синтеза [Куватов Д.М., 2003]. Содержание витамина $\mathrm{B}_{5}$ в зерне ржи составляет 13,0 мг/г (таблица 15). Витамин $\mathrm{B}_{5}$ значительно больше в оболочках зерновки, чем в эндосперме.

Витамин $\mathbf{B}_{6}$ (пиридоксин) играет основную роль в белковом обмене веществ, влияет на обмен жиров и углеводов, усвоение минеральных веществ [Куватов Д.М., 2003]. Содержание витамина В 6 по данным С.Н. Хохрина [2004] в зерне ржи составляет 2,7 мг/г, что несколько выше содержания данного витамина в зерне овса. Распределение витамина $\mathrm{B}_{6}$ в зерновке примерно такое же, как и витаминов $\mathrm{B}_{1}$ и В $\mathrm{B}_{2}$ [Плешков Б.П., 1980, 1987].

Каротин (провитамин А) в стенках кишечника под действием фермента каротиназы превращается в витамин А (ретинол). Витамин А играет важную роль в размножении и росте клеток, обеспечивает нормальное состояние слизистых оболочек, поддерживает зрительные функции сетчатой оболочки глаз [Калашников А.П., 2003]. В растительных кормах содержатся только предшественники витамина А - каратиноиды [Куватов Д.М., 2003].

\section{2. АНТИПИТАТЕЛЬНЫЕ СВОЙСТВА ЗЕРНА ОЗИМОЙ РЖИ}




\section{1. Вещества, снижающие кормовую ценность зерна ржи}

Содержание питательных веществ в зерне ржи подобно пшенице [Miller D.F., 1958], однако питательная ценность его, особенно для домашней птицы, сравнительно низка из-за присутствия различных антипитательных факторов. O неустановленном антипищевом факторе зерна ржи сообщали R.R. Marquardt, A.T. Ward, R. Misir 1979] и T. Antoniou, R.R. Marquardt [1980], который понижал усвоение всех питательных веществ. Наличие в зерне ржи антипитательных веществ, снижающих поедаемость, переваримость и усвояемость животными, ограничивает его использование при кормлении скота и птицы [Аллабердин И.Л., 1999; Солошенко В.А., 1998; Околелова Т., 2001а; Кедрова Л., 2003; Сысуев А.В., 2004а].

В нашей стране практически не изучены вещества, снижающие поедаемость и усвояемость зерна ржи. В отечественной литературе по кормлению сельскохозяйственных животных и птиц [Илюхина Л.А., Кумарин С.В., 1995; Использование..., 1998; Хазиахметов Ф.С., 2001; Калашников А.П., Фисинин В.И., Щеглов В.В., 2003; Использование ..., 2004; Булатов А.П., Лушников Н.А., Миколайчик И.Н., 2005; Мишуров Н.П., 2006; Косолапов В.М., Фицев А.И., Зверкова 3.Н., 2009] на основе обобщенных результутов исследований зарубежных авторов к антипитательным факторам, понижающих поедаемость зерна ржи и усвояемость животными питательных веществ из него относят пектиновые вещества, пентозаны, глюканы, алкалоидные производные 5-алкилрезорцинов, ингибиторов трипсина, фитиновую кислоту, размеры гранул крахмала (таблица 16). Существенным недостатком ржи считается также поражение спорыньей. Наличие ее в корме выше допустимых норм приводит к снижению поедаемости его и абортам.

Таблица 16

Антипитательные факторы ржи

\begin{tabular}{|l|c|}
\hline \multicolumn{1}{|c|}{ Наименование } & Содержание \\
\hline Пентозаны, \% от БЭВ & $6-10$ \\
\hline Пектины, \% от БЭВ & $7-8,5$ \\
\hline Глюканы, \% от БЭВ & $3-4,3$ \\
\hline Фитиновая кислота, \% от СВ & $1,0-1,28$ \\
\hline 5-алкилрезорцины, ед. & 160 \\
\hline Ингибитор трипсина, мг/100 г & $10-20$ \\
\hline Спорынья, \% СВ & $>$ од \\
\hline Крахмал (размер зерна), мкм & $40-50$ \\
\hline
\end{tabular}

Считалось, что причиной низкой поедаемости и переваримости зерна ржи являются 5-алкилрезорцинолы [Wieringa G.W., 1967], которыми особенно богата рожь, а также ингибиторы трипсина [Laporte J., 1962; Polanowski A., 
1967], фитиновая кислота и ее соли [Gontzea I., 1968). G.W. Wieringa[ (1967] сообщил о присутствии некоторых веществ, извлекаемых бензиновым эфиром - алкилрезорцинолов в отрубях ржи. Эти вещества вызвали серьезную депрессию роста у крыс.

В зерне ржи данного соединения содержится 370 мг/кг, пшеницы - 177, ячменя - 48 и овса - 14 мг/кг. По данным L. Munck [1972] в зерне ржи его содержание 161 мг/кг (таблица 17). В.Д. Кобылянский [1982] приводит данные о содержании 5-алкилрезорцинолов в зерне ржи в зависимости от сорта - от 169 до 291 мг/кг. L. Munck [1972] обнаружил значительное колебание содержания алкилрезорцина в пределах одного образца ржи. Более тяжелые зерна, имеющие более высокое отношение эндосперма, в сравнении с легковесным зерном, содержат меньше алкилрезорцинов на одно зерно. Хроматографическое исследование подтвердило, что эти токсические вещества были локализованы в перикарпии и не встречались в эндосперме или зародыше.

Таблица 17

Содержание алкилрезорцинов в зерне ржи, пшеницы и тритикале [Munck L., 1972)

\begin{tabular}{|l|c|c|}
\hline \multicolumn{1}{|c|}{ Культура } & Число сортов & $\begin{array}{c}\text { Содержание } \\
\text { алкилрезорцинов, мг/кг }\end{array}$ \\
\hline Рожь & 15 & 161 \\
\hline Пшеница & 18 & 69 \\
\hline Тритикале & 19 & 97 \\
\hline
\end{tabular}

S.Jakubowski [1979] пришел к выводу, что содержание 5алкилрезорцинолов зависит также от зрелости зерна. В зерне молочной спелости по сравнению со зрелым их в два с лишним раза больше на единицу массы и почти на $60 \%$ больше на единицу поверхности. Эти антипитательные вещества локализованы в перикарпии и не встречаются в эндосперме или зародыше, поэтому в муке их содержание меняется в зависимости от того, какой объем оболочки зерна попадет в нее при помоле. В муке сортового помола обнаружены лишь их следы, а в отрубях их количество максимально. При хранении зерна или муки содержание алкилрезорцинола постепенно уменьшается вследствие его распада.

Установлено значительное колебание алкилрезорцинола в пределах одного образца ржи. Тяжелые зерна, имеющие более высокое соотношение эндосперма к оболочке, в сравнении с легковесными содержат меньше алкилрезорцинолов на единицу массы зерна. Установлена отрицательная зависимость между содержанием 5-алкилрезорцинолов и массой 1000 зерен, то есть чем крупнее зерно, тем меньше сто процентное содержание [Культурная флора СССР, 1989].

Нами изучено содержание 5-алкилрезорцинола в зерне озимой ржи сорта Чулпан, выращенного в условиях Республики Башкортостан. Определение 
данного соединения проводили флюорометрическим методом, описанным Verdea1 и Loreuz [1997]. Результаты анализа показали, что содержание его колебалось от 212 до 396 мг в 1 кг. Вероятно, такие колебания связаны не столько с изменением его концентрации, сколько с изменением соотношения поверхности и массы зерновок. В благоприятных условиях формируются более крупные зерна, у которых удельная площадь поверхности меньше, чем у мелких. В среднем содержание 5-алкилрезорцинола в зерне, выращенном в условиях учхоза Башкирского ГАУ, составило 317 мг в 1 кг (Исмагилов Р.Р., Нурлыгаянов Р.Б., Ванюшина Т.Н., 2001].

Однако R. Fernandes, E. Lucas, J. McGinnis [1973] сообщили, что вещества извлеченные бензиновым эфиром или ацетоном из зерна ржи не ухудшали пищевую ценность зерна для цыплят. Само по себе содержание 5алкилрезорцинолов в зерне не отражается ни на скорости роста, ни на потреблении пищи мышами.

M. Stasiuk и A. Kozubek [1996] указывают, что 5-алкилрезорцин обладает важной биологической функцией регулирующей процесс усвоения поступающей в организм пищи и отвечают за формирование в организме чувства насыщения, подавляют рост клеток злокачественных новообразований. В изученных сортах ржи содержание 5-алкилрезорцинов изменялось от 135 до 300 мг/кг зерна на сухое вещество. Сопоставление данных о росте колоний дрожжей на питательных средах с 5-алкилрезоцинами с результатами влияния определенных количеств 5-алкилрезорцинов на ферментативную активность дрожжей позволило сделать вывод, что микроколичества (до 0,9 мг/мл) данного вещества положительно влияют на дрожжи [Быченкова В.В., Красильников В.Н., 2005].

Трипсин, фермент расщепляющий пептиды и белки, обладает также эстеразной (гидролиз сложных эфиров) активностью. Синтезируется в поджелудочной железе в виде неактивного предшественника (профермента) трипсиногена. Трипсин способен превращать в активные ферменты все проферменты поджелудочной железы (трипсиноген, химотрипсиноген, прокарбоксипептидазу), а также фосфолипазу и в связи с этим занимает ключевое положение в системе пищеварительных ферментов. Активность трипсина подавляется фосфорорганическими соединениями, некоторыми металлами, а также рядом высокомолекулярных белковых веществ ингибиторов трипсина, содержащихся в тканях животных, растений и микроорганизмов [Нортроп Д., 1950; Мосолов В.В., 1971; Теняев А., 2002; Нуртдинов М., 2006]. Ингибитор трипсина ржи был обнаружен А. Поляновским [Polanowski A., 1967] только в эндосперме зерновки. Он сравнительно устойчив при нагревании, хотя ряд авторов не пришли по этому вопросу к единому мнению. R.L. Madl и C.C. Tsen [1973] сообщали о молекулярной массе ингибитора 12000-14000, определенной методом гель-фильтрации. Он обладал термоустойчивостью при $100{ }^{0} \mathrm{C}$ в течение 1 часа. R.L. Madl и C.C. Tsen [1974] также опубликовали данные об ингибиторе химотрипсина в зерне ржи, тритикале и пшенице. Это вещество имело молекулярную массу 17000-19000 и было инактивировано нагреванием в течение 10 мин при $70{ }^{0} \mathrm{C}$. Оба ингибитора 
давали несколько белковых полос при электрофорезе в полиакриламидном геле.

Однако было установлено, что ингибиторы трипсина [Rakowska M., 1985; Tluscik F., 1988] в концентрации, характерной для зерна ржи, не влияют на переваривание и чистое усвоение белков ржи. В противоположность предыдущим сообщениям кормовая ценность как ржи, так и тритикале была выше, чем пшеницы.

Фитиновая кислота (миоинозит гексафосфорная кислота) и ее соли содержатся в алейроновых клетках ржи. Это соединение действует как антипитательный фактор вследствие его способности образовывать плохо растворимые соли с такими минеральными веществами, как кальций, железо, магний и цинк. Согласно сообщениям J.C. Нау [1942] и D.W. Kent-Jones [1967], в промышленных продуктах из пшеницы содержание фитиновой кислоты изменяется аналогично содержанию клетчатки. Как фитиновая кислота, так и ее соли гидролизуются ферментом фитазой с получением инозита и фосфорной кислоты. Пшеница и рожь богаты фитазой, распределение которой в зерне одинаково с ее распределением в субстрате. Фитаза ржи активнее фитазы пшеницы [Gontzea I., 1968]. B тоже время D. Boros [1993, 1985] указывают, что компоненты зерна ржи, растворимые в воде, являются главной причиной плохого усвоения корма.

R. Fernandes, E. Lucas, J. McGinnis [1973] и Т. MacAuliffe, A. Pietraszek, McGinnis [1976] продемонстрировали, что рожь содержала извлекаемые водой вещества, которые понижают рост и минерализацию костей и создают водянистое и липкое содержимое кишечника у цыплят. Эти вещества были разрушены кислотным автоклавированием [MacAuliffe T. Pietraszek A., McGinnis, 1976] или гамма-излучением [MacAuliffe T., Zaviezo D., McGinnis J., 1979]. E.T. Moran, S.P. Jr. Lall, J.D. Summers [1980] и R. Misir, R.R. Marquardt [1978] выдвинули гипотезу, что низкая питательная ценность для домашней птицы и водянистое и липкое содержимое кишечника были, вероятно, из-за наличия полисахаридов в зерне ржи.

Клеточные стенки высших растений состоят из полисахаридов (целлюлозы, гемицеллюлоз, пектинов) и веществ неуглеводного характера (лигнин, кутин, суберин, белки, воска, минеральные соли). Химический состав клеточных стенок представлен в таблице 18.

Таблица 18

Химический состав клеточных стенок зерновки [Никитин Н.И., 1962]

\begin{tabular}{|l|l|l|l|}
\hline \multicolumn{4}{|c|}{ Главнейшие компоненты клеточной стенки } \\
\hline $\begin{array}{l}\text { I. Вся углеводная } \\
\text { фракция }\end{array}$ & 1. Целлюлоза & 1) пентозаны & $\begin{array}{l}\text { а) ксилан } \\
\text { б) арабан }\end{array}$ \\
& & 2) гексозаны & $\begin{array}{l}\text { а) маннан } \\
\text { б) глюкан }\end{array}$ \\
\hline
\end{tabular}




\begin{tabular}{|l|l|l|l|}
\hline & $\begin{array}{l}\text { 2. Гемицеллюлозы } \\
\text { и полиурониды }\end{array}$ & $\begin{array}{l}\text { 3) полиуроновые } \\
\text { кислоты }\end{array}$ & $\begin{array}{l}\text { а) глюкуроновая } \\
\text { кислота } \\
\text { б) } \\
\text { галактуроновая } \\
\text { кислота }\end{array}$ \\
II. Лигнин & $\begin{array}{l}\text { 4) пектины } \\
\text { 5) камеди }\end{array}$ & \\
\hline
\end{tabular}

В стенках клетки зерна каркас из клетчатки заполнен гемицеллюлозой и лигнином. Гемицеллюлоза по своему функциональному назначению и свойствам занимает промежуточное положение между клетчаткой и крахмалом. С одной стороны, как и клетчатка, она является строительным материалом стенок клетки, с другой - запасным питательным веществом, как и крахмал. Ее переваримость составляет 69-95\% [Зверев С.В., 2006]. Гемицеллюлозы состоят из пентозных и гексозных сахаров и являются запасным питательным веществом в оболочках растительных клеток [Калашников А.П., 2003]. Гемицеллюлозы разнородны по строению, молекулярной массе и составу. При гидролизе гемицеллюлозы образуют большое число молекул пентоз (ксилоза и арабиноза), гексоз (галактоза и манноза). В зависимости от входящих в состав цепи моносахаридов, гемицеллюлозы разделяются на пентозаны (ксиланы и арабаны) и гексозаны (мананы и галактаны) [Козьмина Н.П., 1959; Рухлядева Д.М., 1974; Hemicellulose degradation..., 1976].

Существующие соединения гемицеллюлозы (полиозы) М.С. Бардинская делит на группы (таблица 19).

Таблица 19

Классификация полиоз [Бардинская М.С., 1964]

\begin{tabular}{|l|l|}
\hline \multicolumn{1}{|c|}{ Класс А - Однородные полиозы } & \multicolumn{1}{|c|}{ Класс В - Смешанные полиозы } \\
\hline Группа I - полиозы, состоящие из & Группа I - полиозы, состоящие из \\
остатков моноз: & остатков двух различных моноз: \\
1) пентозаны - ксилан, арабан; & 1) пентозаны - арабоксилан; \\
2) гексозаны - маннаны, & 2) пентозаногексозаны - \\
полиглюкозаны, & арабогалактан; \\
галактаны, фруктозаны & 3) гексозаны - коньякманнан, \\
& галактоманнаны \\
\hline Группа II - полиозы, состоящте из & Группа II - полиозы, состоящие из \\
остатков частично этерифицированных & остатков моноз и уроновых кислот: \\
моноз: & 1) камеди - гуммиарабик, камеди \\
маннан салепа, галактаны & сливы и др.; \\
\hline Группа III - полиуроновые кислоты: & 2) растительные слизи \\
пектиновая и альгиновая & \\
\hline
\end{tabular}


Спорынья опасна для животных, а особенно для птицы, так как вызывает сужение периферических кровеносных сосудов, в результате чего наблюдается омертвение гребня, сережек и даже конечностей. У животных она вызывает аборты [Аллабердин И.Л., 1993; Хазиахметов Ф.С., 2001]. Это следует учитывать и скармливать животным только рожь, непораженную спорыньей. В зерне ржи, используемом для приготовления комбикормов, содержание склероции спорыньи [ГОСТ 13496-70] ограничивается 0,1\%. Зерно, содержащее более $0,2 \%$ склероции спорыньи, считается опасным, его нельзя вводить в комбикорма для свиней и птицы. В комбикорма для жвачных такое зерно вводят в ограниченных количествах, не более $10 \%$ по массе. Токсичность ржи, пораженной спорыньей, по мере хранения ослабевает [Стрекозов Н.И., 1998].

\section{2. Пентозаны как основной фактор, снижающий кормовую ценность зерна озимой ржи}

Анализ накопившихся за последние годы экспериментальных данных привел многих исследователей [Antoniou T., Marguardt R.R., 1981; Fengler A.I., Marguardt R.R., 1988a, 1988в; Fengler A.I., Panclic J. R., Marguardt R.R., 1988; Раковска М., Купец Р., Мадей А., 1990; Bengtsson S., Aman P., 1990; Bedford M.R., Glassen H.L., Campbell G.L., 1991; Boros D., Marquardt R.R., Slominsky B.A., 1993; Rakowska M., 1996; Weipert D., 1996] к выводу, что главным фактором, подавляющим общую переваримость и усвояемость белков ржи, является высокое содержание пентозанов (особенно водорастворимые арабиноза и ксилоза, обладающие высокой вязкостью и водопоглощающей способностью).

Еще в 1861 году фон Вибра и в 1867 году Риттенхаузен обнаружили в зерне растворимые углеводы - слизи. Дальнейшее изучение их состава показало, что они в основном состоят из полисахаридов - полимеров пентоз, которые получили название пентозаны. Но кроме слизей, пентозы были обнаружены еще и в других соединениях, в частности, в гемицеллюлозах гетерополисахаридах, которые наряду с целлюлозой входят в состав клеточных стенок растений и могут частично использоваться как запасные вещества. Слизи ржаного зерна почти на $90 \%$ состоят из пентозанов.

Номенклатура гемицеллюлоз и пентозанов довольно сложная вследствие большого разнообразия и сложности содержащихся в этой молекуле сахаров. В научной литературе термины «слизи» и «пентозаны» часто используются как синонимы или, наоборот, как разные вещества. Так, Г.А. Егоров [1985] пишет «помимо крахмала важную роль играют слизи и пентозаны». G.O. Aspinall [1959] показал, что классификация, основанная на различиях растворимости, неточна в отношении химического строения и биологической функции этих соединений. Однако для описательных целей, а также вследствие множественности наименований, применяемых при описании некоторых пентозаносодержащих полисахаридов, термин «гемицеллюлоза» использовался для обозначения водонерастворимых некрахмалистых полисахаридов, а термин «пентозан» - для обозначения водорастворимых полисахаридов. Согласно этим 
определениям, к гемицеллюлозам относятся ксиланы [Aspinall G.O., 1959], очищенные отрубянистые сходы, получаемые при выработке пшеничной муки [Yamazari W.T., 1955], и другие водонерастворимые некрахмалистые полисахариды. К пентозанам относятся пшеничные гумми [Gilles K.A., Smith F., 1956], водорастворимые пентозаны [Montgomerry R., Smith F., 1955] и пентозаны, растворимые в разбавленной кислоте [Пшеница..., 1968].

В более поздних работах R. Karlsson [1988в] дает следующее определение «пентозаны - углеводы, представляющие собой гликопротеиды и обнаруженные в зерне и соломе, где они вместе с лигнинами, протеинами и другим полисахаридами формируют структуру клеточной стенки». По растворимости их в воде они делятся на водорастворимые и нерастворимые. Ржаное зерно содержит 7-10\% пентозанов, из которых водорастворимые 1,52,5\% [Kulp K., 1967] и 1,3-3,5\% [Исмагилов Р.Р., Аюпов Д.С., Ванюшина Т.Н., 2003], зерно пшеницы - 5-7\% пентозанов, из них водорастворимые $-0,5-1,0 \%$ [Kulp K., 1967].

По данным М. Раковска, Р. Купец, А. Мадей [1990] корреляция между их содержанием и усвоением ржаного корма крысами была достоверно отрицательной $(\mathrm{r}=-0,59 \ldots-0,82)$.

T. Antoniou и R.R. Marquardt [1981) проводили эксперименты с целью изучения действия добавок изолированных водорастворимых и водонерастворимых ржаных пентозанов в рацион цыплят. С 6-дневными цыплятами проводились два эксперимента, чтобы определить их рост и усвояемость корма. Изолированные водорастворимые и нерастворимые пентозаны ржи сорта Рuma были добавлены к пшеничным рационам в количестве, примерно равном содержанию водорастворимых пентозанов в ржаных рационах. Содержание водорастворимых пентозанов в зерне ржи Puma было $1,9 \%$, водонерастворимых - 6,5\%. Результаты первого эксперимента показали, что водный экстракт и водорастворимые пентозаны, добавленные к пшеничному рациону, вызывали существенную депрессию массы цыплят и эффективности усвоения корма. Во втором эксперименте, когда водорастворимые пентозаны были добавлены в количестве 1,04 и 1,4\% к пшеничному рациону, наблюдалась депрессия в потреблении корма (от 5 до 17\%), роста (от 19 до 29\%) и эффективности усвоения корма (от 14 до 17\%). Когда в пшеничный рацион добавляли $3,4 \%$ водорастворимых пентозанов, соответствующие депрессии были 34,5 и $33 \%$ по сравнению с пшеничным рационом.

Растворимые в воде пентозаны являлись антипитательным фактором в водном экстракте ржи, потому что высушенный замораживанием экстракт и изолированный растворимый пентозан при добавлении в рацион в приблизительно эквивалентных концентрациях пентозана, вызывали почти одинаковую депрессию роста. Обе фракции образовывали водянистое и липкое содержимое кишечника, которое является характерным для птицы, питающейся зерном ржи.

Водонерастворимые пентозаны, которые обнаружены в более высокой концентрации, чем растворимые, и присоединяют воду без перехода в 
раствор, имеют больший ингибирующий эффект, чем растворимые пентозаны. Результаты эксперимента могут также говорить о том, что нерастворимые пентозаны уменьшают привлекательность (приятный вкус) корма, поскольку у птиц, которых кормили нерастворимыми пентозанами наблюдалось большее разбрасывание корма и удары клювом, чем у птиц, которых кормили растворимыми пентозанами. Этот эффект может быть результатом более высокой концентрации пентозанов, которые делают рацион более липким.

Ржаные пентозаны являются более мощным ингибитором, чем другие полисахариды. Vohra и др. [1979] сообщили, что пектин, каучук quar и каучук arabic, добавленные в рационы в количестве $2 \%$ ингибировали рост цыплят от 4 до 25\%, по сравнению с ингибированием на 29 и 50\%, полученным в данном исследовании с рационами, содержащими соответственно 1,4 и $3,4 \%$ добавленных растворимых и нерастворимых пентозанов.

В сравнительном изучении свойств водорастворимых полисахаридов в зерне (пшеница, ячмень, рожь, овес и кукуруза) I.A. Preece и К.С. Mackenzie [1952] и V. Podrasky [1964] продемонстрировали, что зерно ржи содержит высокую концентрацию водорастворимых пентозанов. По данным А.I. Fengler и R.R. Marguardt [1988a] добавление 1,3\% водорастворимых пентозанов к пшеничному рациону вызвало такую же депрессию роста у цыплят, как и 56\%-ный ржаной рацион.

Добавление фермента уменьшает вязкость содержимого кишечника и улучшает перевариваемость и усвоение корма цыплятами в рационах, содержащих рожь [Patel M.B., McGinnis J., 1980; Groot Wassing J.W.D., Campbell G.L., Classen H.L., 1989]. A.I. Fengler и R.R. Marquardt [1988a, 1988в] продемонстрировали, что добавление целлюлазы из Trichoderma virida к раствору растворимых пентозанов или водному экстракту ржи уменьшило вязкость раствора до уровня воды. Добавление целлюлазы из Trichoderma virida к ржаным рационам цыплят способствовало увеличению накопления жира и сухого вещества и уменьшило вязкость содержимого их кишечника.

O.D. Friesen, W Guenter., B.A.Rotter, R.R. Marquardt [1991] изучали оптимальные дозы ферментов (целлюлазу Trichoderma virida) для добавления в $60 \%$-ный ржаной рацион. Концентрациии ферментов колебалась от 0,05 до 12,8 г фермента на 1 кг корма. Добавление 3,2 г фермента на 1 кг корма вызвало улучшение усвояемости и увеличение массы на 71 и 193\% соответственно. Дальнейшее повышение концентрации фермента не привело к увеличению роста цыплят.

В исследованиях M.R. Bedford, H.L Glassen, G.L. Campbell [1991] также при добавлении пентозаназы из Trichoderma longibrachiatum до 20\% в 60\%ный ржаной рацион петушков бройлеров снизилась концентрация полисахаридных комплексов и вязкость содержимого кишечника, улучшилась перевариваемость корма. 
В последние годы и в отечественной литературе [Гончаренко А.А., 1998, 2000, 2001, 2009; Фисинин В.И., 2000] отмечают, что низкая питательность ряда зерновых обусловлена присутствием в значительных количествах некрахмалистых полисахаридов, к которым и относятся $\beta$-глюканы и пентозаны. Они содержатся в клеточных стенках эндосперма зерна и при лущении не устраняются.

Антипитательные свойства пентозанов обусловлены их способностью связывать большое количество воды. Особенно сорбционной способностью по отношению к воде отличаются растворимые пентозаны. Они могут поглощать в 10 раз больше воды от собственной массы. Растворы пентозанов имеют в 15 раз большую вязкость, чем растворы глобулярных белков. В результате чего в пищеварительном тракте животных образуются высоковязкие суспензии. Скорость прохождения корма через пищеварительный тракт замедляется, что приводит к избыточному размножению микроорганизмов, в том числе патогенных, сокращается потребление корма [Егоров И., 1997; Околелова Т.М., 2001a; Скворцов Е.В., 2004; Тишенков П.И., 2006]. Все это вместе взятое отрицательно отражается на продуктивности скота, росте молодняка и оплате корма продукцией [Удалова Э.В., 1994, 1995; Кошелева Г., 1999; Околелова Т.М., 2001в]. При этом подавляется нормальная микрофлора кишечника и создается реальная угроза инфицирования организма [Кошелева Г., 1999]. В пищеварительном тракте птиц и животных некрахмалистые полисахариды сильно набухают, образуя вязкие клееобразные растворы, обволакивающий гранулы крахмала и протеинов, в свою очередь ограничивающие всасывание уже переваренного белка, крахмала, жира и других важных биологических соединений. В результате в кишечном содержимом повышается концентрация невсосавшихся питательных веществ, которые способствуют развитию условно патогенной микрофлоры в нижних отделах кишечника. Возникают отрицательные последствия: жидкий и клейкий помет, в котором распространяется инфекция и снижение продуктивности птиц и животных [Фисинин В.И., 2000].

В Кубанском ГАУ в 2010-2011 гг. проведена оценка кормовой ценности синтетиков озимой ржи (C-4120 вв и C-4115 нв), созданные на основе групп линий с высокой $(5,5-10,4$ сП) и с низкой $(2,6-3,2$ сП) вязкостью водного экстракта. Данная оценка проведена путем постановки 20-суточных опытов по кормлению цыплят яичного кросса. В качестве контроля использовалось зерно яровой пшеницы сорта МИС. Доля зернового компонента в рационе (рожь или пшеница) составила 69\%. В результате эксперимента установили, что зерно ржи с вязкостью на уровне 3,0$3,5 \mathrm{cП}$ в сравнении с высоковязким $(8,0-9,0$ сП) имеет более высокую переваримость и усвояемость питательных вешеств и по действию на рост цыплят не уступает пшенице. Полученные данные свидетельствуют о возможности снижения содержания высоковязких пентозанов в зерне озимой ржи методами селекции. Селекция на низкую вязкость водного экстракта позволит существенно улучшить кормовую ценность зерна создаваемых сортов ржи [Гончаренко А.А., Цыганкова Н.В, Крахмалев С.В., 2012]. 


\section{3. Состав и свойства пентозанов}

При гидролизе гемицеллюлозы и пентозаны дают производные пентоз и гексоз. Мономерными единицами, чаще всего встречающимися в пентозанах и гемицеллюлозах злаков, являются пентозосахара D-ксилоза и L-арабиноза. Кроме того, имеются данные о наличии некоторых гексозосахаров и их производных. К ним относятся D-галактоза, D-глюкоза, D-глюкуроновая кислота и 4-О-метил-D-глюкуроновая кислота. Их структурные формулы представлены на рисунке 4.

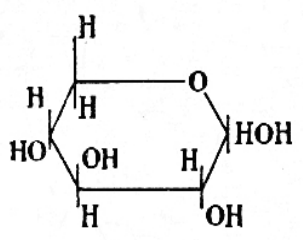

D-ксилоза (I)

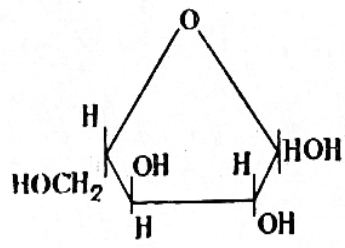

L-арабиноза (II)

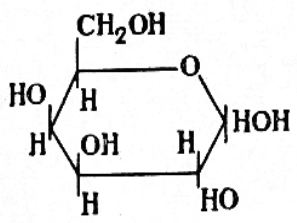

D-галактоза (III)

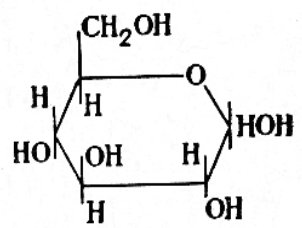

D-глюкоза (IV)

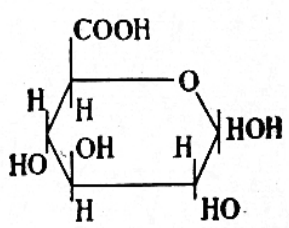

D-глюкуроновая кислота (V)

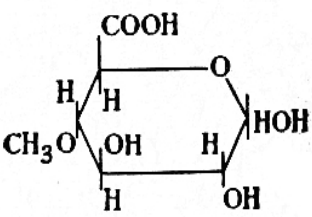

4-О-метил-D-глюкуроновая кислота (VI)

Рисунок 4. Пентозо- и гексозосахара, часто встречающиеся в пентозанах злаков

Гемицеллюлозы и пентозаны, выделяемые из хлебных злаков и трав [Aspinall G.O., 1959; Waite R., Corrod A.R.N., 1959], характеризуются присутствием остатков L-арабофуранозы, соединенных в виде боковой цепи из единственного остатка с основной цепью из D-ксилопиранозных остатков так, как это показано на рисунке 5 .

Обычно боковые цепи присоединяются в положении третьего остатка Dксилозы, однако в некоторых случаях остатки D-глюкуроновой кислоты или 4O-метил-D-глюкуроновой кислоты могут присоединяться в положении 2 или 3 [Пшеница...,1968]. 


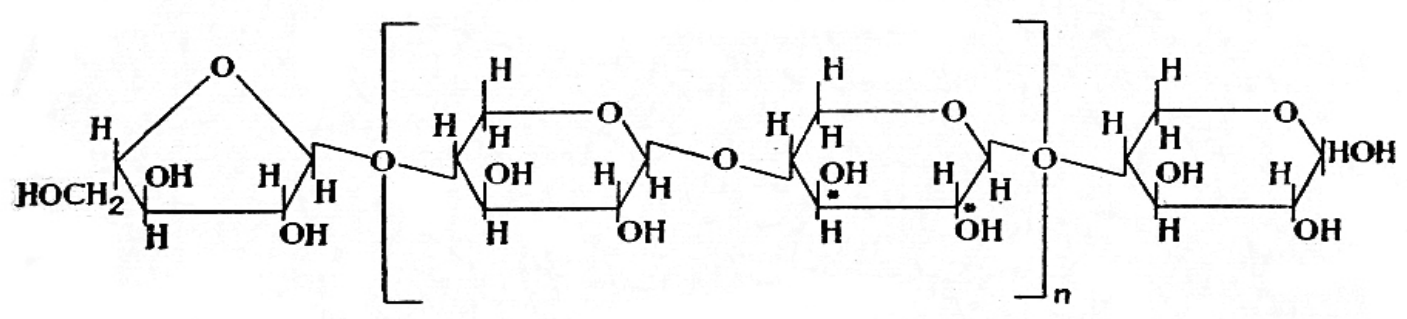

Рисунок 5. Типичная структура пентозана [Пшеница..., 1968]

Обозначения: $n$ - конечное число полимерных остатков; * - положение $\left(C_{2}\right.$ или $\left.C_{3}\right), y$ которого имеет место ветвление.

При изучении состава слизистых веществ зерна ржи установлено, что главным структурным компонентом в них являются водорастворимые пентозаны, на долю которых приходится до 90\% массы слизей [Приезжева Л.Г., Голенков В.Ф.,1970в].

R. Karlsson (1988) изучал свойство и моносахаридный состав пентозанов ржи в сравнении с пентозанами пшеницы и тритикале. Относительное содержание водорастворимых пентозанов в зерне сортов ржи существенно изменялось и изменчивость по годам превысила изменчивости по сортам (таблица 20).

Таблица 20

Содержание пентозанов (арабиноза + ксилоза) в разных сортах ржи, \% к сухой массе (быстрый экспресс метод)

\begin{tabular}{|l|c|c|c|c|c|c|c|c|c|}
\hline \multirow{3}{*}{ Сорта } & \multicolumn{3}{|c|}{1982 г. } & \multicolumn{3}{c|}{1983 г. } & \multicolumn{3}{c|}{1984 г. } \\
\cline { 2 - 11 } & $\begin{array}{c}\text { водо- } \\
\text { раст. }\end{array}$ & $\begin{array}{c}\text { нерас- } \\
\text { твор. }\end{array}$ & общее & $\begin{array}{c}\text { водо- } \\
\text { раст. }\end{array}$ & $\begin{array}{c}\text { нерас- } \\
\text { твор. }\end{array}$ & общее & $\begin{array}{c}\text { водо- } \\
\text { раст. }\end{array}$ & $\begin{array}{l}\text { терас- } \\
\text { твор. }\end{array}$ & общее \\
\hline Petkus II & 1,8 & 6,8 & 8,6 & 2,0 & 6,9 & 8,9 & 1,8 & 7,1 & 8,9 \\
\hline Kungs II & 1,6 & 7,1 & 8,7 & 1,6 & 7,5 & 9,1 & 1,5 & 7,2 & 8,7 \\
\hline Otello & 1,5 & 7,5 & 9,0 & 2,0 & 7,4 & 9,4 & 1,8 & 7,5 & 9,3 \\
\hline Danko & 1,6 & 6,3 & 7,9 & 2,2 & 7,0 & 9,2 & 2,1 & 5,9 & 8,0 \\
\hline Epos & 1,4 & 6,8 & 8,2 & 1,4 & 7,5 & 8,9 & 2,2 & 6,7 & 8,9 \\
\hline Merkaber & 1,5 & 6,5 & 8,0 & 1,8 & 7,1 & 8,9 & 2,1 & 6,5 & 8,6 \\
\hline Ponsi & 1,8 & 6,8 & 8,6 & 2,1 & 7,6 & 9,7 & - & - & - \\
\hline $\begin{array}{l}\text { Östgöta } \\
\text { gråråg }\end{array}$ & 1,5 & 7,5 & 9,0 & 1,7 & 8,1 & 9,8 & 2,2 & 7,5 & 9,7 \\
\hline Pollux & - & - & - & 1,9 & 7,0 & 8,9 & 2,0 & 6,9 & 8,9 \\
\hline Halo & - & - & - & 1,7 & 7,1 & 8,8 & - & - & - \\
\hline $\begin{array}{l}\text { Midsom- } \\
\text { marrag }\end{array}$ & - & - & - & 1,9 & 7,8 & 9,7 & - & - & - \\
\hline Cpeднеe & 1,6 & 6,9 & 8,5 & 1,8 & 7,4 & 9,2 & 2,0 & 6,9 & 8,9 \\
\hline
\end{tabular}


Корреляция нерастворимых пентозанов и общего их содержания по годам составила 0,57 и 0,94 (таблица 21 ).

Таблица 21

Коэффициенты корреляции между годами содержания водорастворимых, нерастворимых и общих пентозанов

\begin{tabular}{|l|c|c|c|c|}
\hline \multicolumn{1}{|c|}{ Пентозаны } & Годы & 1982 г. & 1983 г. & 1984 г. \\
\hline водорастворимые & 1982 & - & 0,63 & $-0,51$ \\
\hline водорастворимые & 1983 & 0,63 & - & $-0,07$ \\
\hline водорастворимые & 1984 & $-0,51$ & $-0,07$ & - \\
\hline нерастворимые & 1982 & - & 0,70 & 0,94 \\
\hline нерастворимые & 1983 & 0,70 & - & 0,57 \\
\hline нерастворимые & 1984 & 0,94 & 0,57 & - \\
\hline общие & 1982 & - & 0,59 & 0,85 \\
\hline общие & 1983 & 0,59 & - & 0,58 \\
\hline общие & 1984 & 0,85 & 0,58 & - \\
\hline
\end{tabular}

Также были обнаружены заметные сортовые различия по содержанию нерастворимых пентозанов. Содержание пентозанов в пшенице было ниже, чем во ржи. По содержанию водорастворимых пентозанов тритикале было ближе к пшенице, нерастворимых - ко ржи. Моносахаридный состав гидролизованных фракций пентозанов был похожим у всех трех зерновых культур (таблица 22).

Таблица 22

Содержание пентозанов (арабиноза+ксилоза) в зерне различных сортов пшеницы и тритикале (экспресс метод) (1982 г.)

\begin{tabular}{|l|l|c|c|c|}
\hline \multirow{2}{*}{ Культура } & \multirow{2}{*}{ Сорт } & \multicolumn{3}{|c|}{ Пентозаны, \% сухому веществу } \\
\cline { 3 - 5 } \multirow{3}{*}{$\begin{array}{l}\text { провая } \\
\text { пшеница }\end{array}$} & растворимые & нерастворимые & общие \\
\cline { 2 - 5 } & Lantverte Dal & 0,7 & 5,6 & 6,3 \\
\cline { 2 - 5 } & Kadett & 0,0 & 5,9 & 6,3 \\
\cline { 2 - 5 } & Sv 80264 & 0,9 & 6,0 & 6,5 \\
\cline { 2 - 5 } & Sv 80433 & 0,9 & 5,5 & 6,4 \\
\cline { 2 - 5 } & Ralle & 0,8 & 5,0 & 5,9 \\
\cline { 2 - 5 } & Salut & 0,7 & 5,7 & 6,5 \\
\cline { 2 - 5 } & Cpeднee & 0,8 & 5,9 & 5,6 \\
\hline \multirow{7}{*}{ Пшеница } & Holme & 0,5 & 4,9 & 6,3 \\
\cline { 2 - 5 } & Solid & 0,4 & 5,4 & 5,4 \\
\cline { 2 - 5 } & LP468971 & 0,9 & 5,2 & 6,1 \\
\cline { 2 - 5 } & Nilder & 0,7 & 4,7 & 5,4 \\
\cline { 2 - 5 } & Sv 76477 & 0,7 & 5,1 & 5,8 \\
\hline
\end{tabular}




\begin{tabular}{|l|l|l|l|l|}
\hline & Среднеe & 0,6 & 5,1 & 5,7 \\
\hline \multirow{7}{*}{ Тритикале } & Sv 8004 & 0,7 & 7,0 & 7,7 \\
\cline { 2 - 5 } & Sv 8005 & 0,7 & 6,8 & 7,5 \\
\cline { 2 - 5 } & Sv 8006 & 1,1 & 7,3 & 8,4 \\
\cline { 2 - 5 } & Sv 8007 & 1,1 & 7,2 & 8,3 \\
\cline { 2 - 5 } & Sv8008 & 1,0 & 6,7 & 7,7 \\
\cline { 2 - 5 } & Sv1810 & 0,9 & 7,5 & 8,4 \\
\cline { 2 - 5 } & Sv 6021 & 1,1 & 7,1 & 8,2 \\
\cline { 2 - 5 } & Sv 6047 & 1,4 & 6,7 & 6,2 \\
\cline { 2 - 5 } & Lasko & 0,7 & 6,1 & 7,9 \\
\cline { 2 - 5 } & Среднее & 1,0 & 6,9 & \\
\hline
\end{tabular}

Однако содержание галактозы в пшенице и тритикале было выше, чем во ржи. Это указывает на то, что арабиногалактан, который имеется в пшенице и тритикале, отсутствует во ржи. Манноза была найдена только в растворимых пентозанах, и ее содержание было выше в пентозанах ржи и тритикале, чем пшеницы (таблица 23). Растворимые пентозаны ржи содержали немного фруктозы, которая вероятно возникла из фруктина (другого растворимого пентозана ржи).

Таблица 23

Молекулярный состав выделенных пентозанов ржи (1983 г.)

\begin{tabular}{|c|c|c|c|c|}
\hline Генотип & $\begin{array}{c}\text { Фракция } \\
\text { пентозанов }\end{array}$ & $\begin{array}{c}\text { Содерж. } \\
\text { белка в } \\
\text { нераств. } \\
\text { остатке, } \\
\text { \% }\end{array}$ & $\begin{array}{c}\text { Содерж. } \\
\text { пентозанов } \\
\text { в экстракте, } \\
\%\end{array}$ & $\begin{array}{c}\text { Моносахаридный состав } \\
\text { ксил.:ара.:гал.:глю.:ман.:фру. }\end{array}$ \\
\hline \multirow[t]{2}{*}{ Epos } & раствор. & 6,7 & 72,2 & 1,00:0,75:0,05:0,09:0,04:0,07 \\
\hline & нераствор. & 13,1 & 67,8 & 1,00:0,65:0,08:1,54: - :- \\
\hline \multirow[t]{2}{*}{ Otello } & раствор. & 6,8 & 81,4 & $1,00: 0,73: 0,06: 0,05: 0,04: 0,04$ \\
\hline & нераствор. & 13,5 & 68,6 & 1,00:0,68:0,08:1,12: - :- \\
\hline \multirow{2}{*}{ Ponsi } & раствор. & 6,9 & 75,9 & $1,00: 0,77: 0,05: 0,12: 0,05: 0,06$ \\
\hline & нераствор. & 13,8 & 73,5 & 1,00:0,65:0,10:1,88: - :- \\
\hline \multirow{2}{*}{$\begin{array}{l}\text { Östgöta } \\
\text { gråråg }\end{array}$} & раствор. & 6,1 & 73,5 & $1,00: 0,76: 0,07: 0,09: 0,04: 0,04$ \\
\hline & нераствор. & 15,7 & 70,1 & 1,00:0,67:0,12:1,50: - : - \\
\hline \multirow[t]{2}{*}{ Halo } & раствор. & 6,1 & 72,2 & 1,00:0,74:0,05:0,13:0,06:0,06 \\
\hline & нераствор. & 12,7 & 77,1 & 1,00:0,61:0,08:1,44:-:- \\
\hline \multirow[t]{2}{*}{ Bjornrag } & раствор. & 7,4 & 76,3 & $1,00: 0,71: 0,05: 0,12: 0,08: 0,05:$ \\
\hline & нераствор. & 15,0 & 70,1 & 1,00:0,64:0,10:1,63: - :- \\
\hline \multirow{2}{*}{$\begin{array}{l}\text { Midsom- } \\
\text { marrag }\end{array}$} & раствор. & 7,3 & 77,2 & $1,00: 0,77: 0,05: 0,12: 0,07: 0,04$ \\
\hline & нераствор. & 14,8 & 69,6 & 1,00:0,69:0,12:1,68: - : - \\
\hline \multirow{2}{*}{$\begin{array}{l}\text { Общее } \\
\text { содерж. }\end{array}$} & раствор. & 6,8 & 75,6 & $1,00: 0,75: 0,05: 0,10: 0,05: 0,05$ \\
\hline & нераствор. & 14,1 & 71,0 & 1,00:0,66:1,10:1,54: - :- \\
\hline
\end{tabular}


В таблице 24 представлен химический состав нерастворимых пентозанов данных сортов. В их составе были обнаружены только сахара: ксилоза, арабиноза и глюкоза. Галактоза и манноза, указанные R. Karlsson [1988в], D.J. Mares и B.A. Stone [1973], F. Meuser и P. Suckow [1986], как часть нерастворимых пентозанов, не была обнаружена в данных образцах, проанализированных методом газовой хромотографии.

Таблица 24

Химический состав нерастворимых пентозанов, извлеченных из муки сортов пшеницы

\begin{tabular}{|l|c|c|c|}
\hline \multicolumn{1}{|c|}{ Сорта } & Протеин, \% & $\begin{array}{c}\text { Арабиноза: Ксилоза: } \\
\text { Глюкоза }\end{array}$ & $\begin{array}{c}\text { Ферулловая } \\
\text { кислота, мг/кг }\end{array}$ \\
\hline Katerwa & $10,7 \pm 0,4$ & $0,647: 1: 0,414$ & $1,08 \pm 0,06$ \\
\hline Glenlea & $12,3 \pm 0,5$ & $0,691: 1: 0,099$ & $\mathrm{NA}^{\mathrm{a}}$ \\
\hline HY 320 & $10,4 \pm 0,4$ & $0,664: 1: 0,099$ & $1,10 \pm 0,04$ \\
\hline Norstar & $8,0 \pm 0,6$ & $0,579: 1: 0,102$ & $0,81 \pm 0,06$ \\
\hline Fielder & $8,0 \pm 0,3$ & $0,591: 1: 0,220$ & $0,61 \pm 0,06$ \\
\hline Marshall & $13,1 \pm 0,4$ & $0,710: 1: 0,331$ & $0,43 \pm 0,03$ \\
\hline Hercules & $12,4 \pm 0,4$ & $0,963: 1: 1,025$ & $0,86 \pm 0,04$ \\
\hline
\end{tabular}

${ }^{a}$ - не анализировалось.

Более высокие отношения арабинозы к ксилозе - показатель степени разветвления (перехода) этих биополимеров [Delcour J.A., Vanhael S., De Geest C., 1989], наблюдались в нерастворимых пентозанах, выделенных из твердой пшеницы (Triticum durum) copта Hercules $(0,963)$ и у поликарликовой яровой краснозерной пшеницы сорта Marshall $(0,710)$.

Более низкие отношения арабинозы к ксилозе $(0,579$ и 0,591$)$ были в нерастворимых пентозанах, выделенных из сортов канадской западной твердозерной озимой краснозерной пшеницы Norstar и канадской западной яровой белозерной пшеницы Flieder, соответственно.

Эти показатели согласуются результатами ранее проведенных исследований S.L. Jelaca, I. Hlynka [1971], S.K. Kim, B.L. D’Appolonia [1976], H.S. Saini, R.J. Henry [1989], кроме нерастворимых пентозанов твердой (Triticum durum) пшеницы (сорт Hercules), для которой S.L. Jelaca, I. Hlynka [1971] сообщали более высокую степень разветвления (перехода) по сравнению с нерастворимыми пентозанами муки канадской западной твердозерной яровой краснозерной пшеницы.

Несмотря на одинаковый метод выделения всех образцов, в нерастворимых пентозанах обнаружено различное количество глюкозы (таблица 24), о которой говорится и в ранее проведенных исследованиях S.K. Kim, B.L. D’Appolonia [1976]. Самое высокое содержание глюкозы, около $50 \%$ от суммы арабинозы и ксилозы, наблюдалось в нерастворимых пентозанах сорта Hercules. У сортов Norstar и HY 320 содержание глюкозы 
было самым низким. Возможно, часть глюкозы в нерастворимых пентозанах сорта Hercules, могла происходить из полимеров бета-глюкана [Mares D.J., Stone B.A., 1973a; Shibuya N., Iwasaki T., 1978; Bacic A., Stone B. A., 1980; Henri R. Y., 1987] или альфа-D-глюкана, которые находятся внутри матрицы нерастворимого полисахарида [Neukom H., 1976; Smith M. M., Hartley R. D., 1983]. В результате его полное удаление при вымывании (бета-глюкан) или обработкой альфа-амилазой (для разрушения крахмала) могло быть затруднено.

Присутствие азотистых соединений в различных количествах в пентозанах пшеницы зарегистрировано E.W. Cole [1967] и D.J. Mares, B.A. Stone [1973в]. Содержание протеина в полученных образцах колебалось от 8,0 до $13,1 \%$ (таблица 24). Наибольшим данный показатель был в нерастворимых пентозанах муки сорта Hercules и Marshall, наименьшим - у Norstar и Fielder. По данным различных исследователей, содержание протеина в нерастворимых пентозанах значительно колеблется и зависит, возможно, от метода выделения [Cole E.W., 1967; JelacaS.L., Hlynka I., 1971] и особенно от того, насколько протеолетические ферменты гидролизуют загрязняющие белки [Mares D. J., Stone B. A., 1973a; Neukom H., 1976; McCleary B.V., 1986]. S.L. Jelaca, I. Hlynka [1971] сообщали о высоком содержании белка в пентозанах, выделенных из зерна твердой пшеницы ( $\mathrm{Tr}$. durum). Было установлено, что белковый компонент нерастворимых пентозанов является неотъемлимой частью клеточных стенок, а не связан ковалентно с нерастворимыми пентозанами [Mares D. J., Stone B. A., 1973a]. Однако, было также показано наличие пересекающих связей (cross-links) между остатками феруллола (feruloyl) и аминокислотами (тирозин и цистеин).

Содержание ферулловой кислоты в муке (таблица 24) находилось в пределах от 0,04 до 0,057 мг/кг, что согласуется с ранее проведенными исследованиями G.M. Jackson, R.C. Hoseney [1986], J. Sosulski, K. Krygier, I. Hogge [1982]. Высокое содержание ферулловой кислоты было обнаружено у copта Hercules $(0,072$ мг/кг). В нерастворимых пентозанах содержание ферулловой кислоты было наибольшим у сорта НY 320 (1,10 мг/кг), Katerwa $(1,08$ мг/кг) и Gercules $(0,86 \mathrm{Mг} / к г)$. Расхождение результатов содержания ферулловой кислоты в муке и в нерастворимых пентозанах указывает на то, что этот элемент неоднородно распределен в эндосперме пшеницы.

Растворимость нерастворимых пентозанов в растворах $\mathrm{NaOH}$ увеличилась с повышением концентрации щелочи. Примерно $80 \%$ нерастворимых пентозанов было растворено в 1,0 M NaOH.

Пентозаны, особенно водорастворимые, характеризуются очень высокой водопоглотительной способностью, которая объясняет их свойство образовывать очень вязкие водные растворы. Исследования вязкости пентозанов [Karlsson R., 1988в] показали, что самую высокую вязкость имеют водорастворимые пентозаны ржи и меньшую - пшеницы. Водорастворимые пентозаны тритикале занимают промежуточное 
положение. Причиной этому, вероятно, являются различия в моносахаридном составе и молекулярной массе.

Водные растворы нерастворимых пентозанов (экстрагированные $\mathrm{NaOH}$, в общем, имели меньшую вязкость, чем соответствующие растворы растворимых пентозанов.

R. Karlsson [1988в] показывает отношение между вязкостью суспензии ржаной муки после 20 мин в вискографе Брабендера и общим содержанием пентозанов в муке. Как ожидалось, вязкость увеличивается с увеличением общего содержания пентозанов.

Однако отсутствует корреляция между содержанием растворимых пентозанов и вязкостью суспензии ржаной муки. Таким образом, нерастворимые пентозаны не формируют высоковязкие растворы экстракта, но они оказывают наибольшее влияние на вязкость суспензии ржаного шрота.

\section{3. ПЕНТОЗАНЫ И ВЯЗКОСТЬ ВОДНОГО ЭКСТРАКТА ЗЕРНА РЖИ}

При исследовании химического состава зерна Вибра и Риттенхаузен обратили внимание на то, что в зерне ржи содержится вещество, которое при обработке размолотого зерна водой или спиртом переходит в раствор, и, которое по своим свойствам близко к растительным слизям. Полученные слизи оказались типичными гидрофильными коллоидами с высокой степенью гидратации. Этим авторы объясняют высокую вязкость растворов слизей. Дальнейшие исследования показали, что в состав слизистых веществ зерна ржи, помимо арабинозы и ксилозы, всегда входит галактоза, глюкоза и фруктоза, а также, в меньших количествах, рамноза и уроновые кислоты [Голенков В.Ф., 1966]. При изучении состава слизистых веществ зерна ржи установлено, что главным структурным компонентом у них являются водорастворимые пентозаны, на долю которых приходится до 90 \% массы слизей [Приезжева Л.Г., 1970a].

Важное свойство арабиноксиланов - способность давать высоковязкие водные растворы при относительно низкой концентрации [Bengtsson S., 1990]. Как уже упоминалось выше, зерно ржи содержит 7-10\% пентозанов. Растворимые в воде арабиноксиланы, не связанные с клеточной мембраной, могут образовывать высоковязкие растворы и адсорбировать приблизительно в десять раз больше своей массы воды [Karlsson R., 1988a; Weipert D., 1996c; Mingan C, 1997].

В исследованиях ряда авторов [Кретович В.Л., 1947, 1948, 1951, 1952; Голенков В.Ф., 1966] указывается, что величина относительной вязкости водных растворов зерна ржи подвержена большим колебаниям, что свидетельствует о различиях в составе слизей. При этом было отмечено, что при изменении внешних условий, а также в зависимости от сорта и вида растения в слизях изменяется соотношение пентозанов и белковых веществ. 
В работах D. Boros, R.R. Marguardt, B.A. Slominsky [1993] были получены результаты, показывающие наличие высокой корреляции между вязкостью экстракта ржи и содержанием водорастворимых пентозанов. Сходные изменения в вязкости у водных экстрактов, приготовленных из пшеничной муки, инкубированных вплоть до 6 часов, были сообщены и в работах А. М. Moore и R. S. Hoseney [1990]. В последующих исследованиях относительная вязкость водных экстрактов образцов, выдержанных при различных уровнях $\mathrm{pH}$ = 2-8, имела параллельные кривые.

Статистический анализ экспериментальных данных, полученных в разных полевых опытах (включающие сорт, сроки уборки) в течение ряда лет подтвердил, что в качестве достаточно надежного, воспроизводимого и не требующего больших затрат показателя оценки содержания в зерне ржи водорастворимых пентозанов может быть вязкость (кинематическая) водного экстракта из зерна. Коэффициент корреляции между содержанием водорастворимых пентозанов и вязкостью водного экстракта составил 0,7100,860 [Гончаренко А.А., 2005в; Тимощенко А.С., 2004; Исмагилов Р.Р., Аюпов Д.С., 2005; Исмагилов Р.Р., 2006].

Таким образом, содержание пентозанов обуславливает вязкость водного экстракта зерна ржи.

\section{1. Вязкость водного экстракта - показатель для оценки содержания водорастворимых пентозанов в зерне озимой ржи}

Количественный анализ содержания водорастворимых пентозанов, одного из основных показателей кормовых свойств зерна, очень трудоемок и дорогостоящий. Поэтому нами проведены исследования с целью разработки более экономичного и доступного метода оценки содержания пентозанов в зерне ржи. Как было указано выше, существует определенная связь между содержанием в зерне водорастворимых пентозанов (арабиноксиланов) и вязкостью водного экстракта. Однако необходимо выяснить, насколько надежно вязкость водного экстракта отражает содержание пентозанов в зерне разных сортов, выращенных в различных климатических условиях. Следовало также уточнить форму связи и количественно описать зависимость вязкости водного экстракта от содержания пентозанов в зерне ржи. Для этого нами [Исмагилов Р.Р., Ахиярова Л.М. ] проводились корреляционно-регрессионный анализ параллельных данных лабораторного анализа зерна 7 сортов, выращенных в течение 3-х лет (2005-2007 гг.) на территории Учебно-научного центра Башкирского ГАУ.

Корреляционный анализ экспериментальных данных показал, что теснота связи между содержанием водорастворимых пентозанов и вязкостью водного экстракта зерна ржи очень высокая $(\mathrm{r}=0,935)$. При исключении влияния года (погодных условий) теснота данной связи повышается. Так, в 2007 году коэффициент корреляции составил 0,986, т.е. практически функциональная связь. Форма связи содержания водорастворимых пентозанов и вязкости 
водного экстракта прямолинейная (рисунок 6). Уравнение регрессий имеет следующий вид:

$$
\mathrm{y}=22,67 \mathrm{x}-16,38
$$

где У - вязкость водного экстракта, $\mathrm{cCt}$;

$\mathrm{x}$ - содержание водорастворимых пентозанов в зерне, \%.

Согласно данному уравнению, при изменении содержания водорастворимых пентозанов на $1 \%$ вязкость водного экстракта повышается на $22,67 \mathrm{cCt}$. Данное уравнение может быть использовано для характеристики содержания водорастворимых пентозанов в зерне озимой ржи.

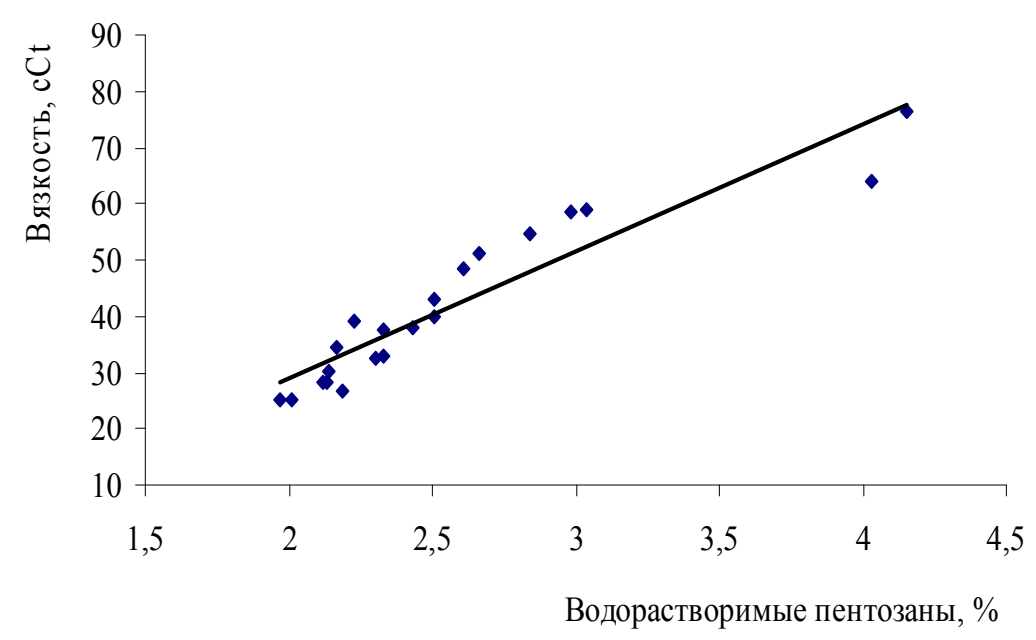

Рисунок 6. Зависимость вязкости водного экстракта от содержания водорастворимых пентозанов в зерне озимой ржи (УНЦ Башкирский ГАУ, 2005-2007 гг.)

Дополнительно для учета влияния почвенных и климатических условий провели изучение параллельных данных лабораторного анализа зерна из 3-х госсортоучастков (Давлекановский, Калатасинский, Балтачевский), расположенных в разных природных зонах Республики Башкортостан. При включении фактора «почва» и «климат» теснота связи существенно не снизилась. Коэффициент корреляции между вязкостью водного экстракта и содержанием водорастворимых пентозанов в образцах зерна, взятых из разных госсортоучастков, составил в 2005 году $+0,919$, в 2006 году $+0,926$, в 2007 году $+0,824$.

Таким образом, вязкость водного экстракта достаточно точно характеризует содержание водорастворимых пентозанов в зерне ржи. Следовательно, для оценки содержания водорастворимых пентозанов можно пользоваться показателем «вязкость водного экстракта» из зерна как косвенный метод.

\section{4. КОРМОВЫЕ КАЧЕСТВА ЗЕРНА СОРТОВ ОЗИМОЙ РЖИ}


Одним из перспективных направлений повышения питательности зерна озимой ржи является создание специальных сортов с высокими кормовыми качествами [Гончаренко А.А., 2009]. Улучшение кормовых качеств зерна ржи может быть достигнуто путем селекции на низкое содержание водорастворимых пентозанов, изменение их структуры и высокое содержание белка при высокой устойчивости к прорастанию зерна в колосе. Несомненно, такие сорта будут более успешно конкурировать с тритикале [Гончаренко А.А., 2000, 2009; Бишарев А.А., Михайлов Н.В., Горянина Т.А., 2012].

Целенаправленная селекция сортов кормового назначения в России начата только в последние годы в рамках ГНТП «Рожь». На наш взгляд, в настоящее время, когда селекция кормовых сортов озимой ржи находится на начальном этапе, целесообразно проведение оценки кормовых свойств зерна и отбор имеющихся в производстве сортов пригодных в той или иной степени для кормовых целей. Исследовательская работа в данном направлении в стране не проводилась, и информация о кормовых свойствах зерна различных сортов, особенно по содержанию антипитательных веществ, соответственно, практически отсутствует. Наши исследования показали на возможность в определенной мере снижения содержания водорастворимых пентозанов в зерне озимой ржи (до 50\%) с помощью селекции, сортировки и длительного хранения зерна [Исмагилов Р.P., 2011].

\section{1. Питательность зерна сортов озимой ржи}

Как показали наши исследования, зерно озимой ржи сортов разного экологического типа (Чулпан 7, Чулпан, Ирина, Саратовская 7, Антарес, Снежана, Паром) имеет сравнительно одинаковую энергетическую питательность.

Энергетическая кормовая единица (1 ЭКЕ равна 10 МДж обменной энергии в 1 кг корма) изменялась по годам и сортам от 1,13 до 1,16, т.е. питательность зерна изученных сортов несколько выше средних показателей. По данным С.Н. Хохрина [2004] величина энергетической кормовой единицы зерна ржи в среднем составляет 1,12. В то же время зерно сортов между собой несколько отличались по энергетической питательности. Так, сорт Саратовская 7 (в среднем за 2005-2006 гг.) имеет несколько ниже ЭКЕ $(1,13)$, чем остальные сорта $(1,15-1,16)$ (таблица 25).

Таблица 25

Энергетическая питательность зерна сортов озимой ржи (УНЦ Башкирский ГАУ, 2005-2006 гг.)

\begin{tabular}{|c|c|c|}
\hline \multirow{2}{*}{ Сорт } & \multicolumn{2}{|c|}{ В среднем за 2005-2006 гг. } \\
\cline { 2 - 3 } & ЭКЕ & ОЭ $^{*}$, МДж/кг \\
\hline Чулпан 7 (стандарт) & 1,15 & 11,5 \\
\hline
\end{tabular}




\begin{tabular}{|l|l|l|}
\hline Чулпан & 1,15 & 11,5 \\
\hline Ирина & 1,15 & 11,5 \\
\hline Саратовская 7 & 1,13 & 11,3 \\
\hline Антарес & 1,16 & 11,6 \\
\hline Снежана & 1,16 & 11,6 \\
\hline Паром & 1,16 & 11,6 \\
\hline
\end{tabular}

ЭКЕ - энергетическая кормовая единица; ОЭ* - обменная энергия.

Однако энергетическая оценка является обобщающей и не отражает сбалансированность корма по отдельным питательным веществам. Отсутствие или недостаток в корме хотя бы одного из питательных веществ ухудшает использование корма, приводит к снижению продуктивности животного. Питательность зерна ржи определяется также содержанием в нем комплекса органических и минеральных веществ: протеин, жир, углеводы (клетчатка, сахара, крахмал), макро- и микроэлементы, витамины [Хазиахметов Ф.С., 2004]. В этой связи нами проводилось изучение содержания основных питательных веществ в зерне различных сортов.

Содержание протеина в зерне изменялось по сортам и годам проведения опытов от 7,55\% до $11,58 \%$. Эти данные несколько ниже средних величин (12,0\%) данного показателя, что, вероятно, связано с высокой урожайностью зерна в опытах $(3,5-4,3$ т/га). Известно, что при высокой урожайности концентрация белка в зерне снижается. При сравнении содержания белка по годам видно, что наибольшим оно было зарегистрировано в 2007 году и наименьшим - в 2006 году (таблица 26).

Таблица 26

Содержание питательных веществ в зерне сортов озимой ржи, \% (УНЦ Башкирский ГАУ, 2005-2006 гг.)

\begin{tabular}{|l|c|c|c|c|c|}
\hline \multicolumn{1}{|c|}{ Сорт } & $\begin{array}{c}\text { Переваримый } \\
\text { протеин* }\end{array}$ & Крахмал & Клетчатка & Жир & Сахара \\
\hline $\begin{array}{l}\text { Чулпан 7 } \\
\text { (контроль) }\end{array}$ & 9,76 & 65,70 & 4,12 & 2,13 & 1,47 \\
\hline Чулпан & 9,72 & 65,83 & 3,99 & 2,11 & 1,43 \\
\hline Ирина & 9,57 & 65,18 & 4,12 & 2,13 & 1,43 \\
\hline Саратовская 7 & 8,28 & 65,43 & 3,39 & 2,10 & 1,52 \\
\hline Антарес & 9,81 & 66,30 & 4,19 & 2,11 & 1,50 \\
\hline Снежана & 10,77 & 66,40 & 4,42 & 2,13 & 1,45 \\
\hline Паром & 10,47 & 65,11 & 4,57 & 2,11 & 1,45 \\
\hline
\end{tabular}

* в среднем за 2005-2007 г2.

Из экспериментальных данных следует наличие значительной межсортовой вариации содержания переваримого протеина в зерне ржи. В 2005 году оно изменилось от 8,04\% (сорт Саратовская 7) до $10,38 \%$ (сорт Снежана) и в остальные годы наблюдалась аналогичная закономерность. В 
среднем за 3 года (2005-2007 гг.) максимальное содержание протеина было установлено в зерне сорта Снежана $(10,77 \%)$ и Паром $(10,47 \%)$, а минимальное - в зерне сорта Саратовская 7 (8,28\%). По содержанию протеина в зерне сорта Чулпан 7, Чулпан, Ирина, Антарес занимали промежуточное положение (9,579,81\%). В зерне гибрида Пикассо содержание сырого белка составило 10,9\% [КВC РУC, 2010].

В зависимости от сорта и года содержание крахмала в зерне изменялось от 64,52 до 66,70\%, что несколько выше средних литературных данных (60\%). Межсортовое отличие этого признака, как показывают данные, небольшое и закономерного преимущества того или иного сорта не наблюдается. В разные годы содержание крахмала варьировало по сортам. Если в 2005 году максимальное содержание крахмала было обнаружено в зерне сорта Снежана $(66,30 \%)$, то в 2006 году - сорта Чулпан (66,70\%). Это, вероятно, обусловлено различной нормой реакции изученных сортов на погодные условия в период вегетации растения. В среднем за 2 года (2005-2006 гг.) сорта Антарес, Снежана и Ирина несколько отличались по содержанию крахмала от контрольного сорта Чулпан 7.

Клетчатка, труднопереваримый углевод, играет важную роль в пищеварении животных. Содержание клетчатки в зерне варьировало по годам и сортам от 3,24 до 4,58\%. Среди изученных сортов низким содержанием клетчатки $(3,39 \%)$ выделился сорт Саратовская 7 и сравнительно высоким сорт Снежана $(4,42 \%)$ и Паром (4,57\%). Данную межсортовую вариацию содержания клетчатки можно в определенной мере объяснить крупностью зерновок. Известно, чем крупнее зерновка, тем меньше ее удельная поверхность (оболочка). Оболочка в основном представлена клетчаткой. Масса 1000 зерен сорта Саратовская 7 в среднем была в наших опытах 28,7 г, а сорта Паром $-27,9$ г.

По литературным данным среднее содержание простых сахаров в зерне ржи 1,5\% [Хохрин С.Н., 2004]. В наших опытах содержание сахаров изменялось по сортам в 2005 году от 1,38 до 1,41\%, в 2006 году - от 1,44 до $1,56 \%$. В среднем наибольшее содержание сахаров было в зерне сортов Саратовская 7 (1,52\%) и Антарес $(1,50 \%)$.

Содержание жира в зерне изученных сортов в среднем было несколько выше литературных данных и изменялось сравнительно незначительно - от 2,10 до 2,13\%. Среднее содержание сырого жира в зерне ржи составляет 1,9\% [Хохрин С.Н., 2004].

Таким образом, зерно изученных сортов по энергетической питательности существенно не отличается. Более высоким содержанием переваримого протеина отличаются сорта Снежана и Паром, наименьшим сорт Саратовская 7. Зерно сорта Саратовская 7 содержит также меньше клетчатки, чем контрольный сорт Чулпан 7, а в сортах Снежана и Паром содержится больше клетчатки. Содержание сырого жира в зерне гибрида Пикассо составило 1,38\% [КВС РУС, 2010].

Минеральные вещества играют важную роль в обмене веществ организма животных [Хохрин С.Н., 2004]. В условиях Республики 
Башкортостан обеспеченность кормов особенно низка марганцем, йодом и цинком, что связано с низким содержанием их в почве [Микроэлементозы сельскохозяйственных ...., 1967; Гирфанов В.К., 1975; Исмагилова Э.Р., 2005].

Содержание фосфора в зерне изменялось по годам и сортам от $0,26 \%$ до 0,30\%. В 2007 году по сравнению с 2005 и 2006 годами у большинства сортов ржи зерно формировалось с большим содержанием фосфора, что связано с засушливым условием в период созревания зерна. Наблюдается определенное отличие сортов по данному показателю. Сравнительно низким содержанием фосфора выделяется во все годы сорт Саратовская 7 (0,267\%), высоким содержанием - сорта Паром $(0,290 \%)$ и Снежана $(0,287 \%)$ (таблица 27$)$.

Таблица 27

Содержание золы и макроэлементов в зерне сортов озимой ржи, \% (УНЦ Башкирский ГАУ, 2005-2007 гг.)

\begin{tabular}{|l|c|c|c|c|c|c|}
\hline \multicolumn{1}{|c|}{ Сорт } & Зола & Фосфор & Калий & Кальций & Натрий & Магний \\
\hline $\begin{array}{l}\text { Чулпан 7 } \\
\text { (контроль) }\end{array}$ & 3,07 & 0,283 & 0,457 & 0,087 & 0,0870 & 0,113 \\
\hline Чулпан & 3,26 & 0,283 & 0,453 & 0,083 & 0,087 & 0,110 \\
\hline Ирина & 2,95 & 0,290 & 0,453 & 0,087 & 0,083 & 0,113 \\
\hline Саратовская 7 & 3,19 & 0,267 & 0,437 & 0,080 & 0,083 & 0,107 \\
\hline Антарес & 2,90 & 0,283 & 0,453 & 0,087 & 0,087 & 0,113 \\
\hline Снежана & 2,95 & 0,287 & 0,453 & 0,090 & 0,083 & 0,117 \\
\hline Паром & 2,84 & 0,290 & 0,456 & 0,090 & 0,090 & 0,113 \\
\hline
\end{tabular}

Растения озимой ржи потребляют на единицу формируемого урожая значительно больше калия, чем других элементов минерального питания (Прокошев В.В., 2000). Содержание калия в зерне в зависимости от года и сорта варьировало от $0,43 \%$ до $0,46 \%$. По сравнению с остальными сортами содержание данного элемента ниже в зерне сорта Саратовская 7 (в среднем за 3 года 0,437\%). У контрольного сорта Чулпан 7 оно составило 0,457\%. Причем, относительно низкое содержание калия в зерне сорта Саратовская 7 $(0,43-0,44 \%)$ наблюдалось во все годы проведения опытов.

Кальция в зерне ржи изученных сортов было в пределах средних значений $(0,08-0,09 \%)$. Межсортовое отличие данного показателя было незначительным. Содержание натрия составило в пределах 0,08-0,09\%. Какоелибо закономерное изменение содержания данного элемента в зерне изученных сортов не проявилось. Магния в зависимости от года и сорта изменялось от 0,10 до $0,12 \%$. В 2007 году по сравнению с остальными годами отмечалось сравнительно низкое содержание магния в зерне ржи $(0,105 \%)$. Относительно меньше было содержание магния в зерне сорта Саратовская 7 (в среднем за 3 года $0,107 \%)$, в то время у сорта Чулпан $7-0,113 \%$.

Особое место в кормление животных занимают микроэлементы. Недостаток их приводит к микроэлементозу. Согласно данным В.В. 
Ковальского (1974) в кормах оптимальное содержание микроэлементов составляет: меди - 3-12 мг/кг, марганца - 20-60, цинка - 20-60 и йода - 0,07$1,2 \mathrm{мг} / \mathrm{кг.}$

Содержание марганца варьировало по годам и сортам от 17,62 до 26,15 мг/кг, что ниже средних данных (30 мг/кг) [Хохрин С.Н., 2004]. По годам содержание марганца в зерне сортов изменялись неодинаково. Так, у сорта Чулпан 7 в 2005 году оно было самое низкое (17,76 мг/кг), а в 2006 году, наоборот, самое высокое $(26,15$ мг/кг) среди изученных сортов. Это объясняется более сильной зависимостью данного признака от условий формирования зерновки, чем от генотипа. В то же время наблюдается сравнительно низкое содержание марганца в годы исследований в зерне сорта Саратовская 7 - в среднем 18,86 мг/кг (таблица 28).

Таблица 28

Содержание микроэлементов в зерне сортов озимой ржи, мг/кг (УНЦ Башкирский ГАУ, 2005-2006 гг.)

\begin{tabular}{|l|c|c|c|c|c|}
\hline \multicolumn{1}{|c|}{ Сорт } & Марганец & Йод & Медь & Цинк & Железо \\
\hline Чулпан 7 (контроль) & 21,95 & 0,115 & 7,61 & 88,33 & 62,80 \\
\hline Чулпан & 21,02 & 0,110 & 7,64 & 94,62 & 63,10 \\
\hline Ирина & 23,08 & 0,110 & 7,58 & 92,21 & 61,90 \\
\hline Саратовская 7 & 18,86 & 0,095 & 7,87 & 90,69 & 64,10 \\
\hline Антарес & 20,35 & 0,115 & 7,84 & 88,54 & 63,50 \\
\hline Снежана & 22,89 & 0,120 & 7,60 & 89,42 & 64,65 \\
\hline Паром & 23,78 & 0,120 & 7,48 & 86,83 & 63,00 \\
\hline
\end{tabular}

Йода в зерне различных сортов в наших опытах было несколько выше, чем данные, приводимые в литературе, и изменялось по годам от 0,09 до 0,12 мг/кг. Среди изученных сортов меньшим содержанием данного микроэлемента выделился сорт Саратовская 7. Если у контрольного сорта Чулпан 7 содержание йода в зерне составило в среднем за 2 года проведения опытов (2005-2006 гг.) 0,115\%, то у сорта Саратовская 7 - 0,095\%. Несколько большим содержанием йода отличаются сорта Снежана и Паром (0,12 мг/кг).

Содержание меди в зерне у разных сортов за годы исследования изменялось от 7,38 до 7,91 мг/кг, что оказалось несколько выше средних данных, приводимых в литературе (6,7 мг/кг) [Хохрин С.Н., 2004]. В отличие от других микроэлементов содержание меди в зерне сорта Саратовская 7 больше, чем у остальных сортов. В годы проведения опытов содержание меди в зерне данного сорта было в среднем 7,87 мг/кг, а у сорта Чулпан 7 - 7,61 мг/кг. Заметно меньше содержание меди в зерне сорта Паром - 7,48 мг/кг.

Цинка в зерне озимой ржи оказалось высоким и изменялось по годам от 79,51 до 96,56 мг/кг. Содержание данного элемента в зерне озимой ржи обычно составляет 20 мг/кг, а оптимальным считается содержание цинка в концентрации 20-60 мг/кг [Ковальский В.В., 1974]. В годы исследований 
содержание цинка в зерне сортов озимой ржи было разным. В 2006 меньше, чем в 2005 году. Если в 2005 году наименьшее содержание данного микроэлемента было в зерне сорта Антарес (89,89 мг/кг), то в 2006 году у сорта Паром (79,51 мг/кг). Поэтому определенной закономерности межсортового отличия содержания цинка не наблюдалось.

Железо - один из самых распространенных в природе элементов. Растениями поглощается в обменной форме [Обыденова Л.А., 2003]. За годы исследований межсортовая изменчивость в содержании железа составила от 61,90 (сорт Ирина) до 64,65 мг/кг (сорт Снежана), что незначительно отличается от средних литературных данных (63 мг/кг) [Хохрин С.Н., 2004]. Сравнительно выше содержание железа было в 2006 году, при незначительном межсортовом отличии (таблица 28).

\section{2. Сорт и содержание пентозанов в зерне ржи}

Долгое время различия между сортами ржи по содержанию пентозанов и их составу не были обнаружены [Drews E., 1976]. Пригодность ржи для хлебопечения определяли по числу падения, активности альфа-амилазы или на амилографе [Weipert D., 1983, 1988, 1996b]. Было установлено, что вредные в кормовом отношении пентозаны являются полезными в хлебопечении. Это обстоятельство составляет большую проблему для селекции, так как необходимо вести работу в разных направлениях, чтобы получить сорта для хлебопечения и кормления животных [Гончаренко А.А., 1998].

В Белорусии более $90 \%$ посевных площадей под рожью занято тетраплоидными сортами. При этом диплоидные сорта при одинаковых значениях числа падения имеют более значительные показатели высоты амилограммы, содержат больше пентозанов, дают более качественный хлеб с пористостью и большим объемным выходом. Тетраплоидная рожь имеет более низкие значения высоты амилограммы, температуру клейстеризации крахмала и поэтому более пригодна на кормовые цели, но белка содержит меньше. Содержание крахмала в зерне тетраплоидной ржи составляет 6065\%, диплоидной - 55-60\% [Урбан Э.П., 2002].

В таблице 29 приводится группировка сортов Белорусии для разного целевого использования по содержанию пентозанов и активности амилолитических ферментов [Урбан Э.П., 2003; Горелик В.В., 2004].

Таблица 29

Группировка сортов для разных целей использования

\begin{tabular}{|l|l|l|}
\hline Цель использования & \multicolumn{1}{|c|}{ Задачи селекции } & Предлагаемые сорта \\
\hline Хлебопечение & $\begin{array}{l}\text { Низкая активность } \\
\text { амилолитических ферментов, } \\
\text { устойчивость к } \\
\text { предуборочному прорастанию. }\end{array}$ & $\begin{array}{l}\text { Диплоидная рожь: } \\
\text { Ясельда, Зубровка, } \\
\text { Зарница }\end{array}$ \\
\hline
\end{tabular}




\begin{tabular}{|c|c|c|}
\hline & $\begin{array}{l}\text { Высокое содержание общих и } \\
\text { растворимых пентозанов }\end{array}$ & \\
\hline $\begin{array}{l}\text { Получение } \\
\text { комбикормов и } \\
\text { крахмала }\end{array}$ & $\begin{array}{l}\text { Повышенное содержание белка } \\
\text { и крахмала. Низкое содержание } \\
\text { общих и растворимых } \\
\text { пентозанов. Устойчивость к } \\
\text { предуборочному фузариозу }\end{array}$ & $\begin{array}{l}\text { Тетраплоидная } \\
\text { рожь: Верасень, } \\
\text { Игуменская, } \\
\text { Сябровка, } \\
\text { Спадчина, Завея } 2\end{array}$ \\
\hline Переработка на спирт & $\begin{array}{l}\text { Повышенное содержание } \\
\text { крахмала. Высокая натурная } \\
\text { масса зерна. Высокое } \\
\text { содержание общих и низкое - } \\
\text { растворимых пентозанов }\end{array}$ & $\begin{array}{l}\text { Диплоидная рожь: } \\
\text { Радима, Калинка, } \\
\text { Талисман }\end{array}$ \\
\hline
\end{tabular}

R. Karlsson [1988a] выяснил, что относительное содержание водорастворимых пентозанов в зерне различных сортов ржи было непостоянным по годам и колебание по годам превысило колебание по сортам. Содержания нерастворимых пентозанов между сортами ржи были более постоянными, а также одинаковыми за 3 года изучения.

В исследованиях, проведенных А.А Гончаренко, Р.Р. Исмагиловым и Н.С. Беркутовой [2005], показатели качества зерна сильно варьировали под влиянием генотипических и средовых факторов. Из всех признаков наибольшая межсортовая вариабельность отмечена по вязкости водного экстракта. Различия превысили варьирование таких интегральных признаков как высота амилограммы и число падения, отражающих состояние весьма сложных гетерогенных систем, какой является углеводно-амилазный комплекс зерна.

Содержание водорастворимых пентозанов за 2002-2004 годы исследований в условиях Республики Башкортостан изменялось у разных сортов от 1,38 до 3,23 \% на сухое вещество [Исмагилов Р.Р., Галикеев А.Г., Аюпов Д.С., 2003; Исмагилов Р.Р., Галикеев А.Г., 2004а]. Наибольшее содержание в зерне водорастворимых пентозанов было у гибрида НВП-3, наименьшее - у сортов Безенчукская 87 и Исеть.

В опытах, проведенных с 7 сортами озимой ржи в 2005-2007 гг. [Исмагилов Р.Р., Ахиярова Л.М.] в условиях Республики Башкортостан, содержание водорастворимых пентозанов изменялось от 1,97 до 4,15\%. Коэффициент вариации данного признака составил $22,44 \%$. Данный коэффициент показывает на сравнительно высокую изменчивость содержания водорастворимых пентозанов в зерне ржи. Содержание пентозанов зависело как от условий формирования зерна на материнском растении, так и от сорта. Так, содержание их в зерне сорта Чулпан 7 от условий года изменялось от 2,33 до $2,84 \%$. Межсортовое изменение в 2007 году было от 1,97\% (сорт Саратовская 7) до 3,04\% (сорт Ирина). Дисперсия данного признака от условий формирования зерна составила $11,6 \%$, а от сорта $-82,6 \%$. Данные результаты показывают значительное отличие сортов по содержанию водорастворимых пентозанов. У изученных сортов среднее содержание водорастворимых пентозанов в зерне в 
годы исследований изменялось от $2,13 \%$ до $3,74 \%$ на сухое вещество (рисунок 7).

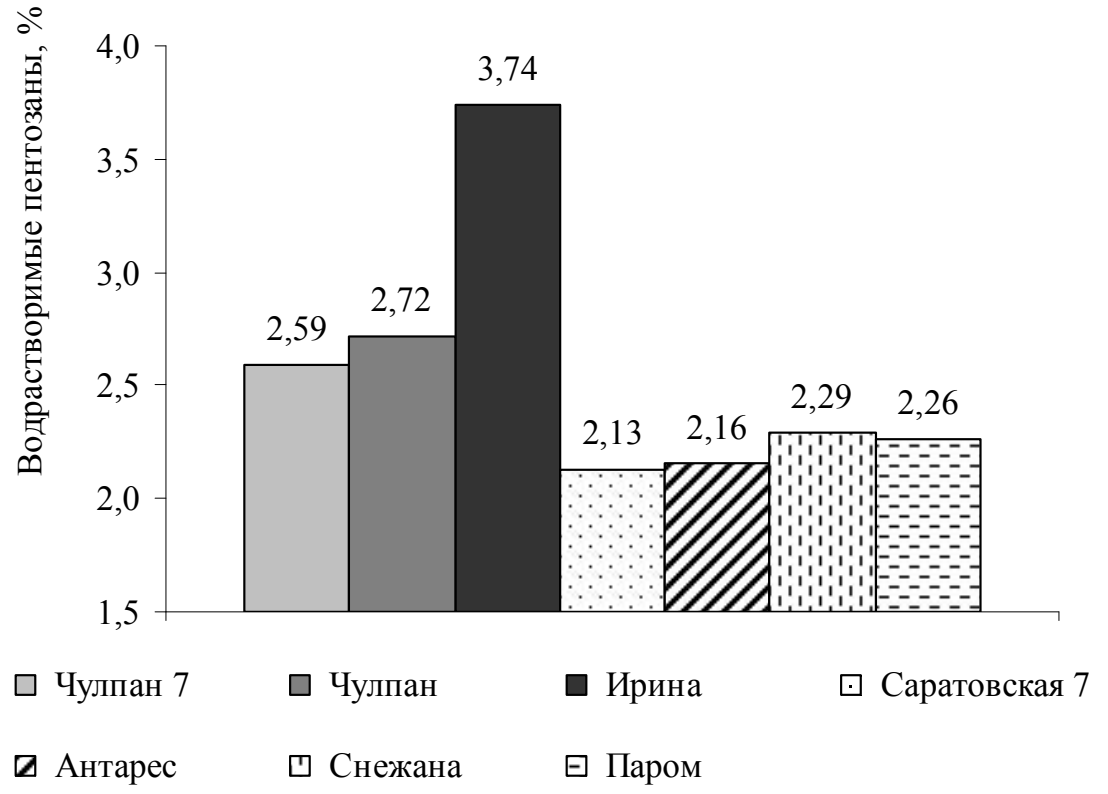

Рисунок 7. Содержание водорастворимых пентозанов в зерне сортов озимой ржи (УНЦ Башкирский ГАУ, 2005-2007 гг.)

Наибольшее содержание в зерне водорастворимых пентозанов было в среднем за годы исследования у сорта Ирина $(3,74$ \%), а наименышее - у сорта Саратовская 7 (2,13\%). Сравнительно низкое содержание водорастворимых пентозанов имели сорта Антарес (2,16 \%), Снежана (2,29\%) и Паром (2,26\%). Контрольный сорт Чулпан 7 по содержанию водорастворимых пентозанов занимал среднее положение (2,59\%). Примерно на таком же уровне было содержание водорастворимых пентозанов у сорта Чулпан (2,72\%). Данная закономерность наблюдалась во все годы исследования (2005-2007 гг.).

Максимальное межсортовое отличие содержания водорастворимых пентозанов сортов Ирина и Саратовская 7 составило 1,76 раза. Все сорта, за исключением сорта Чулпан, по содержанию водорастворимых пентозанов в 2005 году статистически существенно отличались от контрольного сорта Чулпан 7. В то же время разница в содержании водорастворимых пентозанов в 2005 г. между сортами Саратовская 7, Антарес, Снежана и Паром, в 2006 году между сортами Саратовская 7 и Антарес, в 2007 году между сортами Снежана, Паром, Саратовская 7 и Антарес статистически была несущественна.

По исследованиям сортов разного географического происхождения (Чулпан 7, Безенчукская 87, Антарес, Роксана, Саратовская 7, Марусенька, Ирина, Снежана, Паром, Тантана) в 2011 году также наблюдалась значительная межсортовая изменчивость. Самой низкой вязкостью водного экстракта зерна обладали сорта Саратовская 7 (19,58 cCt), Марусенька $(20,80 \mathrm{cCt})$, а самой высокой - сорт Ирина $(59,09 \mathrm{cCt})$. По сравнению с контрольным сортом Чулпан 7 (48,06 cCt) вязкость водного экстракта у всех сортов, за исключением сорта Ирина, была ниже [Ахиярова Л.М., Исмагилов Р.Р., 2012]. 
Ряд авторов [Karlsson R. 1988b; Gan Y.T., 1996a, 1998] указывает, что содержание пентозанов находится в определенной связи с массой и размером зерновки. При этом выявлено, что в мелкой зерновке их содержится больше, чем в крупной.

Сопоставление экспериментальных данных, полученных нами, также показывает наличие связи между массой зерновки (масса 1000 зерен) и содержанием водорастворимых пентозанов.

Масса 1000 зерен на растении формируется под влиянием условий года, а также она отличается у изученных сортов. Так, масса 1000 зерен у одного и того сорта (Чулпан 7) изменялась по годам от 26,10 г до 30,10 г и соответственно содержание водорастворимых пентозанов от 2,33\% до 2,84\%. Масса зерновки (масса 1000 зерен) у исследуемых сортов существенно отличалась между собой (таблица 30 ).

Таблица 30

Масса 1000 зерен и содержание водорастворимых пентозанов в зерне сортов озимой ржи

\begin{tabular}{|l|c|c|c|c|c|c|}
\hline \multirow{2}{*}{ Сорт } & \multicolumn{2}{|c|}{2005 г. } & \multicolumn{2}{c|}{2006 г. } & \multicolumn{2}{c|}{2007 г. } \\
\cline { 2 - 8 } & $\begin{array}{c}\text { масса } \\
1000 \\
\text { зерен, г }\end{array}$ & $\begin{array}{c}\text { водораств. } \\
\text { пентозаны, } \\
\%\end{array}$ & $\begin{array}{c}\text { масса } \\
1000 \\
\text { зерен, г }\end{array}$ & $\begin{array}{c}\text { водораств. } \\
\text { пентозаны, } \\
\%\end{array}$ & $\begin{array}{c}\text { масса } \\
1000 \\
\text { зерен, г }\end{array}$ & $\begin{array}{c}\text { водораств. } \\
\text { пентозаны, } \\
\%\end{array}$ \\
\hline $\begin{array}{l}\text { Чулпан 7 } \\
\text { (контроль) }\end{array}$ & 26,10 & 2,61 & 29,71 & 2,84 & 30,10 & 2,33 \\
\hline Чулпан & 25,13 & 2,66 & 28,19 & 2,98 & 29,54 & 2,51 \\
\hline Ирина & 24,12 & 4,03 & 27,30 & 4,15 & 28,86 & 3,04 \\
\hline Саратовская 7 & 26,30 & 2,12 & 29,76 & 2,30 & 30,17 & 1,97 \\
\hline Антарес & 27,67 & 2,14 & 31,20 & 2,33 & 30,08 & 2,01 \\
\hline Снежана & 26,20 & 2,23 & 29,34 & 2,51 & 28,80 & 2,13 \\
\hline Паром & 25,40 & 2,17 & 28,83 & 2,43 & 29,60 & 2,19 \\
\hline
\end{tabular}

Межсортовая вариация данного признака, например, в 2007 году составила от 28,80 г до 30,17 г. Наиболее высокой массой 1000 зерен отличается сорт Антарес (27,67-31,20 г), а наименьшей - сорт Ирина (24,1228,86 г).

Корреляционно-регрессионный анализ показал наличие тесной связи между массой 1000 зерен и содержанием водорастворимых пентозанов в зерне сортов в пределах одного года. В 2005 году коэффициент корреляции составил $-0,769$, в 2006 году $-0,789$ и в 2007 году -0,573. Причем, данная связь достаточно прямолинейна и она отрицательная (рисунок 8). 


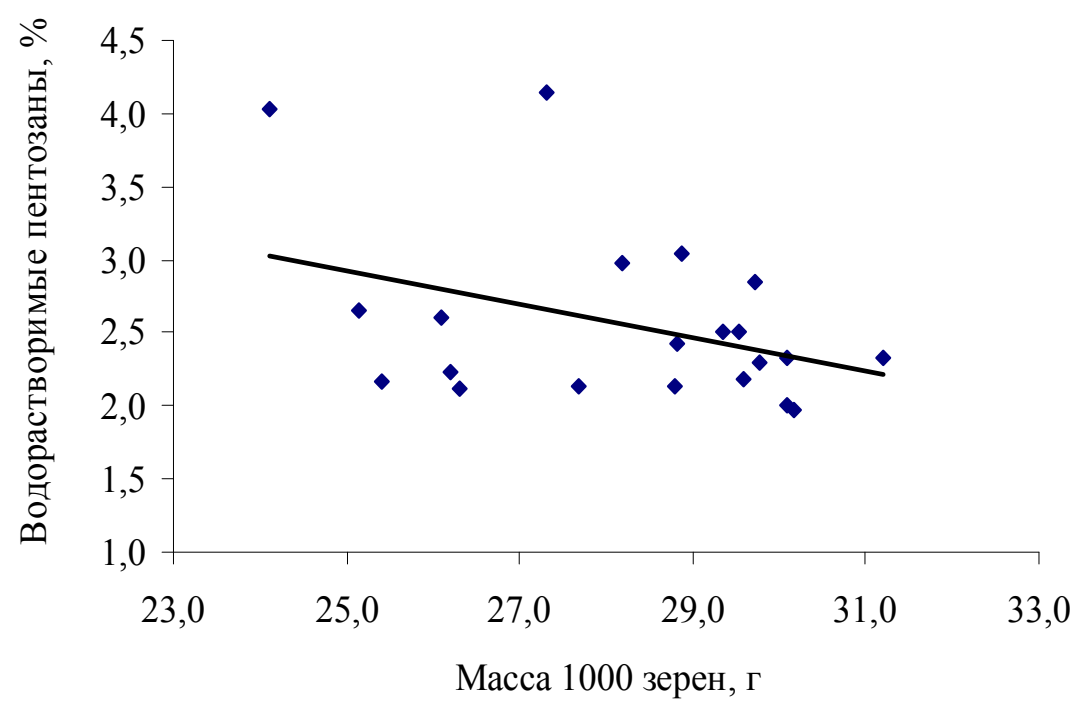

Рисунок 8. Зависимость содержания водорастворимых пентозанов в зерне сортов озимой ржи от их массы 1000 зерен (УНЦ Башкирский ГАУ, 20052007 гг.)

Однако при анализе данных за ряд лет теснота данной связи резко снижается $(\mathrm{r}=-0,386)$. Это, вероятно, связано с влиянием погодных условий на массу зерновки и на содержание пентозанов в разных направлениях.

Зависимость содержания водорастворимых пентозанов от массы 1000 зерен описывается следующим уравнением регрессии:

$$
\mathrm{y}=-0,1154 \mathrm{x}+5,8125
$$

где У - содержание водорастворимых пентозанов в зерне, \%;

$\mathrm{x}$ - масса 1000 зерен, г.

Согласно данному уравнению при увеличении массы 1000 зерен на 1 г содержание водорастворимых пентозанов снижается на $0,1154 \%$.

Таким образом, сорта озимой ржи с крупным зерном содержат водорастворимых пентозанов меньше, чем сорта с мелким зерном. В тоже время по коэффициенту корреляции можно судить, что масса зерновки неполностью определяет содержание пентозанов в зерне разных сортов озимой ржи. Следовательно, кроме массы зерновки, есть другие факторы межсортовой вариабельности содержания в зерне водорастворимых пентозанов.

Для того, чтобы выявить степень влияния факторов, кроме массы 1000 зерен, на содержание пентозанов в зерне нами проводилось определение его у зерен одного и того же размера. Для этого разделили зерновую массу на фракции по размеру (толщине) зерновки при помощи набора сит. Выбор разделения зерен по размеру менее трудоемок, чем их разделение по массе. Кроме того, размеры зерновки и их масса сильно взаимосвязаны.

Как показывают результаты исследования зерна одной и той же фракции (т.е. одинакового размера) у разных сортов также отличаются по содержанию водорастворимых пентозанов. Так, зерна с толщиной 2,0-2,2 мм содержали пентозаны (в среднем за 3 года) у сорта Чулпан $7-2,67 \%$, сорта Чулпан - 
2,80\%, сорта Ирина - 3,90\%, сорта Саратовская 7 - 2,17\%, сорта Антарес $2,25 \%$, сорта Снежана $-2,66 \%$ и сорта Паром - 2,33\% (рисунок 9).

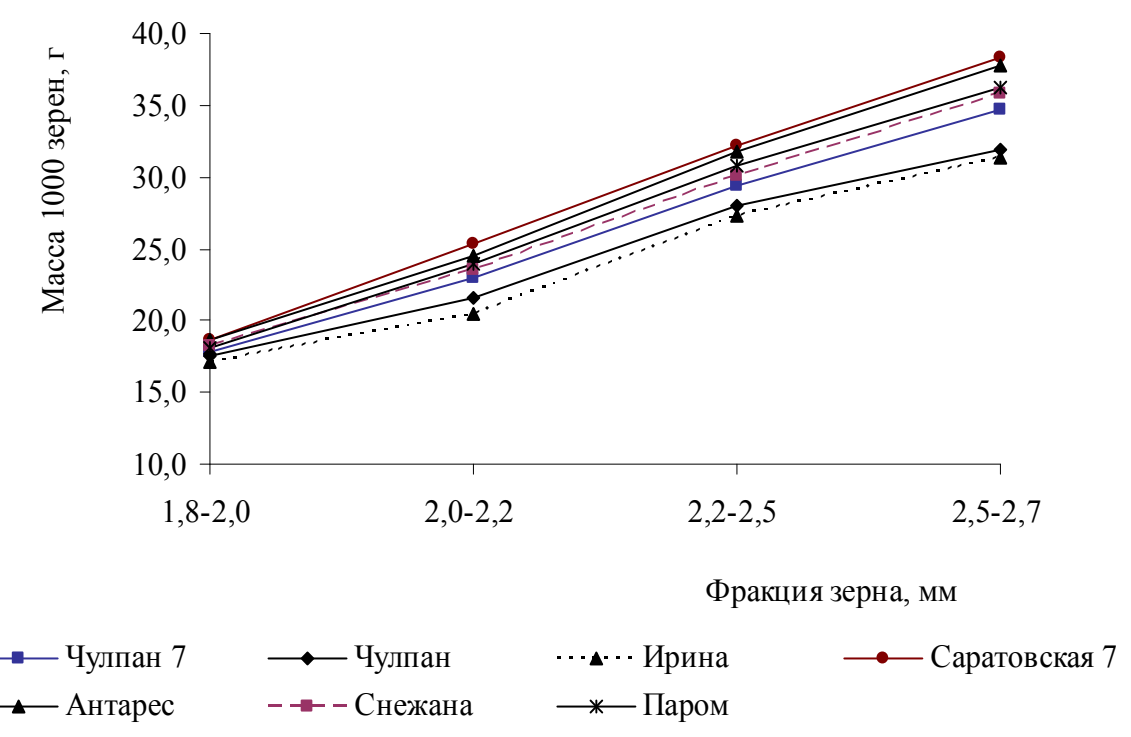

Рисунок 9. Изменение массы 1000 зерен от их толщины (УНЦ Башкирский ГАУ, 2006 г).

Сорта по возрастанию содержания водорастворимых пентозанов в зерновке одной и той же толщины располагаются в следующем порядке: Саратовская 7, Антарес, Паром, Снежана, Чулпан 7, Чулпан и Ирина. Данный порядок изменения содержания пентозанов сохранился и в общей массе зерна.

Максимальная разница между содержанием пентозанов в зерне фракции 2,0-2,2 мм по сортам составила $1,73 \%$. Данная закономерность в содержании водорастворимых пентозанов в зависимости от сорта наблюдается во всех фракциях зерна. Следовательно, изменчивость содержания пентозанов у разных сортов обусловлена, кроме размера зерновки, в значительной мере другими внутренними факторами. Одним из факторов межсортовой изменчивости содержания пентозанов, возможно, является разная молекулярная масса пентозанов в зерне разных сортов. По исследованиям А.А. Гончаренко $[2008,2009]$ зерно сортов ржи с высокой вязкостью имели макромолекулы пентозанов, соответственно, с более высокой молекулярной массой, чем со средней и низкой вязкостью. Молекулярная масса пентозанов оказывает сильное влияние на вязкость их водного экстракта $(\mathrm{r}=0,95)$. В.Д. Кобылянский (2009) указывает, что на содержание водорастворимых пентозанов влияет толщина оболочек зерновки.

Как показали наши исследования, количество белка в зерне также взаимосвязано с содержанием водорастворимых пентозанов. С увеличением содержания белка снижается содержание водорастворимых пентозанов в зерне озимой ржи, хотя теснота данной связи очень слабая $(\mathrm{r}=-0,228)$.

Нами изучалось также содержание общих пентозанов в зерне озимой ржи разных сортов в течение трех лет. Содержание общих пентозанов изменялось по годам и сортам от $9,53 \%$ до $12,90 \%$. 
Полученные нами данные по содержанию общих пентозанов несколько отличались от данных R. Karlsson [1988b].

Как и водорастворимые пентозаны, наибольшее содержание общих пентозанов было в зерне сорта Ирина $(12,35 \%$ в среднем за 3 года) и наименьшее - в зерне сортов Антарес $(10,62 \%)$ и Саратовская $7(10,68 \%)$ (рисунок 10).

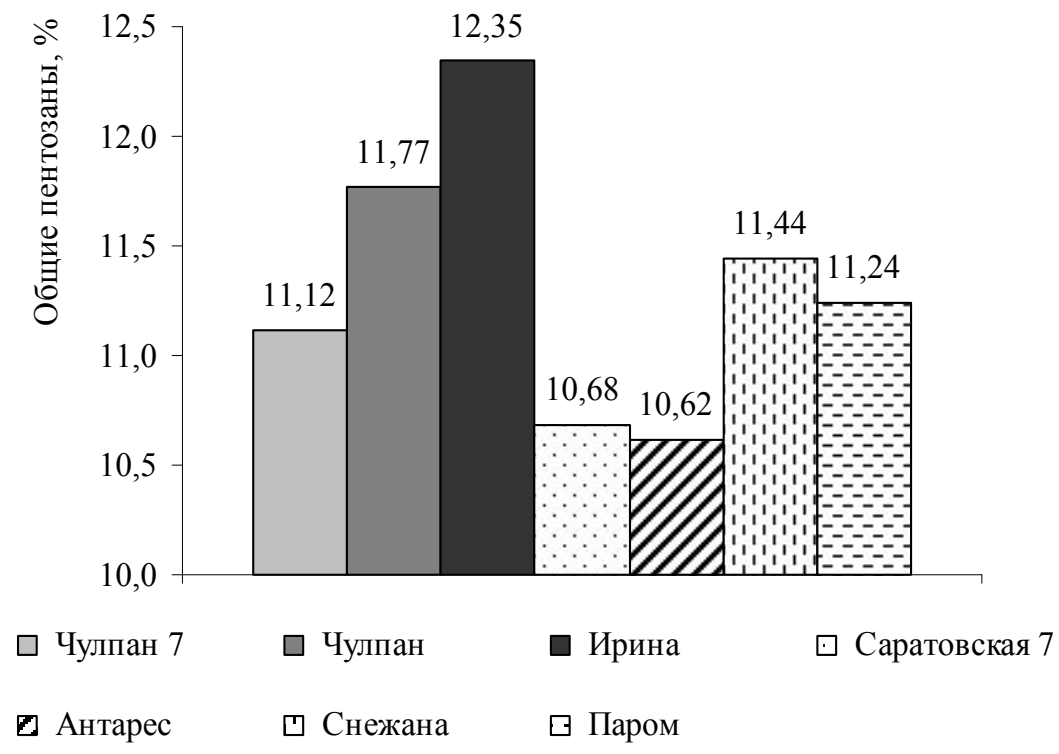

Рисунок 10. Содержание общих пентозанов в зерне сортов озимой ржи (УНЦ Башкирский ГАУ, 2005-2007 гг.).

Между содержанием водорастворимых и общих пентозанов имеется достаточно тесная связь. Коэффициент корреляции составил 0,883. Этим объясняется изменение двух видов пентозанов в одном направлении.

По вязкости водного экстракта, как и предполагалось, наблюдается значительная межсортовая изменчивость. Так, в среднем за годы исследования (2005-2007 гг.) по сравнению с контрольным сортом (Чулпан 7) меньшей вязкостью водного экстракта отличились сорта Саратовская $7(28,60 \mathrm{cCt})$ и Антарес $(29,37 \mathrm{cCt})$, а наибольшей - сорт Ирина $(66,32 \mathrm{cCt})$. Остальные сорта занимали промежуточное положение, за исключением сорта Чулпан $(51,90 \mathrm{cCt})$, который приближался по данному показателю к контрольному сорту Чулпан 7. Данная закономерность наблюдалась во все годы исследования (рисунок 11). 


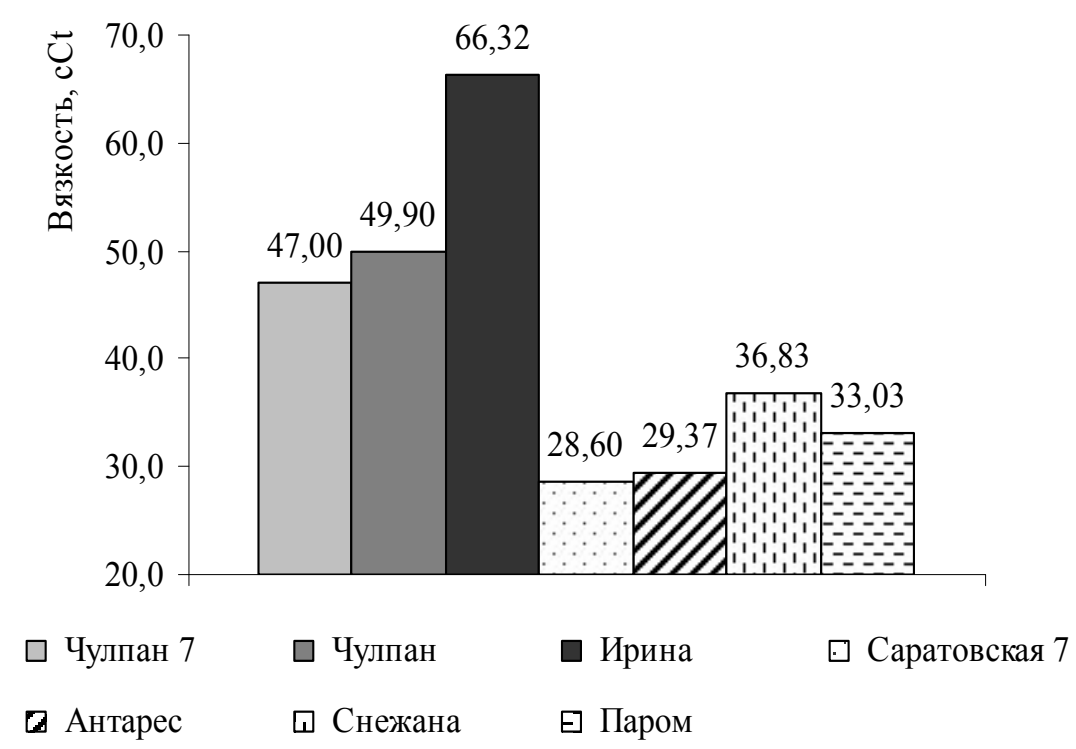

Рисунок 11. Вязкость водного экстракта зерна сортов озимой ржи (УНЦ Башкирский ГАУ, 2005-2007 гг.)

В научной литературе имеются экспериментальные данные о влиянии гидротермических условий в период роста и развития растений на качество зерна [Беркутова Н.С., 1991; Исмагилов Р.Р., 1998].

Исследования в 2002-2011 гг. показали, что содержание пентозанов в зерне озимой ржи в значительной мере зависит от гидротермических условий в период формирования, налива и созревания зерна (в условиях южной лесостепи Республики Башкортостан «3 декада июня - 2 декада иоля») [Исмагилов Р.P., Галикеев А.Г., Ахиярова Л.М., 2012]. Коэффициент корреляции между среднесуточной температурой воздуха в период «3 декада июня - 2 декада иоля» и содержанием водорастворимых пентозанов зерна озимой ржи сорта Чулпан 7 составил $\mathrm{r}=0,54$.

Таким образом, содержание основного антипитательного вещества зерна озимой ржи (пентозанов) определяется особенностями сорта и зависит от условий вегетации растения.

А.А. Гончаренко [2000, 2009] указывает, что пентозаны и их структура должны быть объектом пристального внимания селекционеров, биохимиков и технологов. При создании кормовых сортов ржи предпочтение следует отдавать отбору форм с низким содержанием пентозанов.

\section{3. Активность пентозаназ}

В зернах злаков имеется по крайне мере 3 типа ферментов, разлагающих пентозаны - пентозаназы: эндоксиланаза, $\beta$-ксилозидаза и $\alpha$-арабинозидаза [Kulp K., 1967; Jochansson H., Hall O., Sellergen E., Thulin L., 1971; Weipert D., Zwingelberg H., 1980]. Эндоксиланаза гидролизует арабиноксилан произвольно на всем протяжении молекулы, в то время $\beta$-ксилозидаза с одного конца, а $\alpha$ арабинозидаза освобождает арабинозу от молекул арабиноксилана. 
Ферментативная активность в зерне, не только $\alpha$-амилазы увеличивается с начала его формирования, но также и пентозаназы, липазы и протеазы. Низкую вязкость суспензии ржаной муки в образцах 1984 г. можно было бы в конечном счете объяснить ферментативной активностью. Для выяснения характера влияния пентозаназ (главные образующие - эндоксиланазы) на хлебопекарные свойства у трех сортов ржи Kungs II, Danko и Östgöta gråråg были определены активность $\alpha$-амилазы и пентозаназы в период формирования и созревания зерна. Образцы сортов ржи, выращенные в 1982-1984 гг., были проанализированы только в полной зрелости [Karlsson R., 1988a]. Ферментативная активность и содержание воды в зерне сорта Kungs II в 1983 и 1984 гг. определяли в образцах созревшего зерна, пророщенного в лаборатории. Зерно было погружено на 2 часа в воду, затем помещено между влажными фильтровальными бумагами при комнатной температуре. Развитие пентозаназной активности было подобно $\alpha$-амилазе - с высокой активностью на ранних стадиях но быстрым снижением к полной спелости. $\alpha-$ амилазная активность осталось низкой до прорастания в оба года, в то время как пентозаназная активность осталась низкой только в 1983 г. В 1984 г. увеличение пентозаназной активности наблюдалось перед созреванием при влажности зерна 45-50\%. Она осталась на высоком уровне до созревания и при прорастании. Таким образом, в один год пентозаназы очевидно синтезировались перед $\alpha$-амилазой, в то время как в другой год они вероятно синтезировались одновременно. Однако, если процесс прорастания происходил медленнее, разница во времени могла бы быть обнаружена в материалах 1983 г. тоже. Можно предположить, что пентозаназы, особенно эндоксиланаза, синтезируется перед $\alpha$-амилазой. Это кажется вероятным, потому что пентозаназы должны разрушить клеточную стенку и проложить путь для других ферментов во время прорастания. Высокая пентозаназная активность, вероятно, является причиной низкой вязкости ржаной суспензии в образцах 1984 г. Молекулярные массы молекул пентозанов уменышается в зависимости от активности эндоксилоназы.

Как известно, на ферментативную активность оказывают влияние погодные условия. Июль в 1982 и 1983 гг. был теплее и суше, чем в обычные годы, в тоже время в 1984 г. погода, наоборот, была холодная в течение этого месяца. Рожь обычно убирается в южной Швеции в первой половине августа. Все сорта, убранные в фазе спелости в 1984 г. имели более высокую пентозаназную активность, чем образцы 1982 и 1983 гг. (таблица 31).

Таблица 31

Ферментативная активность различных сортов ржи (1982-1984 гг.)

\begin{tabular}{|c|c|c|c|}
\hline & $\begin{array}{c}\text { Уменьшение } \\
\text { вязкости } \\
\text { Сорта }\end{array}$ & $\begin{array}{c}\alpha \text {-амилазная } \\
\text { (эндоксиланазная } \\
\text { активность), } \\
\text { сСt/ мин. } \times 10^{2}\end{array}$ & $\begin{array}{c}\text { Читивность, К }(\alpha) \\
\text { падения, с. }\end{array}$ \\
\hline
\end{tabular}




\begin{tabular}{|c|c|c|c|}
\hline \multicolumn{4}{|c|}{1982 г. } \\
\hline Petkus II & 5,5 & 2 & 278 \\
\hline Kungs II & 3,1 & 2 & 256 \\
\hline Otello & 4,0 & 2 & 280 \\
\hline Danko & 3,1 & 2 & 257 \\
\hline Epos (VSB 2546) & 4,7 & 1 & 266 \\
\hline Merkator & 2,9 & 1 & 252 \\
\hline Ponsi & 2,2 & 1 & 263 \\
\hline Östgöta gråråg & 6,0 & 2 & 270 \\
\hline Среднее & 3,9 & 1,6 & 265 \\
\hline \multicolumn{4}{|c|}{1983 г. } \\
\hline Petkus II & 2,9 & 1 & 301 \\
\hline Kungs II & 1,8 & 2 & 268 \\
\hline Otello & 2,4 & 1 & 314 \\
\hline Danko & 2,7 & 2 & 275 \\
\hline Epos (VSB 2546) & 3,3 & 1 & 289 \\
\hline Merkator & 2,0 & 1 & 290 \\
\hline Ponsi & 0,9 & 2 & 317 \\
\hline Östgöta gråråg & 2,9 & 2 & 305 \\
\hline Pollux & 3,3 & 3 & 229 \\
\hline Среднее & 2,5 & 1,9 & 287 \\
\hline \multicolumn{4}{|c|}{1984 г. } \\
\hline Petkus II & 9,3 & 6 & 146 \\
\hline Kungs II & 9,6 & 4 & 215 \\
\hline Otello & 11,1 & 1 & 314 \\
\hline Danko & 11,1 & 10 & 156 \\
\hline Epos (VSB 2546) & 12,9 & 6 & 188 \\
\hline Merkator & 9,1 & 9 & 153 \\
\hline Östgöta gråråg & 12,2 & 8 & 167 \\
\hline Pollux & 10,7 & 20 & 118 \\
\hline Среднее & 10,8 & 8,0 & 182 \\
\hline
\end{tabular}

Cорта Otello и Kungs II имели высокую пентозаназную активность, как и все остальные сорта. Это подтверждает предположение, что сорта по $\alpha$ амилазной и пентозаназной активности не всегда одинаковы. В некоторые годы была выше пентозаназная активность, чем число падения, которая характеризовалась вязкостью ржаной суспензии. Корреляция между пентозаназной активностью и числом падения отсутствует. Однако имеется корреляция в пентозаназной активности по годам ( $\mathrm{r}=0,798$ (1982-1983 гг.); $\mathrm{r}=0,63$ (1983-1984 гг.); $\mathrm{r}=0,43$ (1982-1984 гг.). Так, сорта Еpos и Östgöta grarag имели большую активность, в то время как Merkator, Kungs II и Ponsi меньшую активность во все три года. 


\section{5. ВЯЗКОСТЬ ВОДНОГО ЭКСТРАКТА ЗЕРНА РЖИ В ЗАВИСИМОСТИ ОТ СРОКА ХРАНЕНИЯ}

Зерно ржи следует скармливать сельскохозяйственным животным через 23 месяца после уборки, т.к. количество пентозанов при хранении зерна или муки постепенно уменьшается вследствие их распада [Стрекозов Н.И., 1998]. Особенно много растворимых некрахмалистых полисахаридов содержится в свежеубранном зерне, которое в свою очередь создает гораздо больше проблем с вязкостью, чем хранившееся [Егоров И., 1997; Околелова Т.М., 2001в, 2002; Okolelova T., 2002].

В.М. Косолапов, А.И.Фицев и З.Н.Зверкова 2009] указывают, что «Рожь нельзя использовать сразу после уборки до тех пор, пока в зерне не прекратятся процессы брожения и превращения веществ». Нельзя использовать на корм зерно свежеубранную рожь, так как происходящие в зерне процессы послеуборочного дозревания вызывают расстройство пищеварения животных [Гончаренко А.А., 2009]. Послеуборочное дозревание зерна продолжается в первые три месяца хранения [Мачихина Л., 2006]. Свежеубранное зерно имеет повышенную вязкость, стабилизация которой в процессе созревания наступает лишь через 3-4 месяца после уборки урожая [Околелова Т. М., 2006а; Кончакова Е., 2002]. Т. Околелова, Е. Кончакова [2006а] во ВНИТИП совместно с кафедрой энзимологии МГУ изучили изменение динамической вязкости хранившегося зерна различных сортов пшеницы и ячменя из разных регионов России (таблица 32). Вязкость экстракта зерна определяли по методике А.П. Синицына вискозиметрическим способом.

Таблица 32

Динамика вязкости водного экстракта зерна в процессе хранения

\begin{tabular}{|c|c|c|c|c|c|}
\hline \multirow{3}{*}{$\begin{array}{c}\text { Культура, сорт, } \\
\text { район культивирования }\end{array}$} & \multicolumn{5}{|c|}{ Вязкость, сПз } \\
\hline & \multirow{2}{*}{$\begin{array}{c}\text { на } \\
\text { момент } \\
\text { посту- } \\
\text { пления }\end{array}$} & \multicolumn{4}{|c|}{$\begin{array}{c}\text { продолжительность } \\
\text { хранения, месяц }\end{array}$} \\
\hline & & 1 & 2 & 3 & 4 \\
\hline $\begin{array}{l}\text { Пшеница, Ярославская обл., } \\
\text { поступила 27.09.2001 г. }\end{array}$ & 66,9 & 26,3 & 8,09 & 8,0 & 7,9 \\
\hline $\begin{array}{l}\text { Пшеница, Ростовская обл., } \\
\text { Орловский р-он } \\
\text { поступила 26.08.2001 г. }\end{array}$ & 75,5 & 55,7 & 25,8 & 8,8 & 8,8 \\
\hline $\begin{array}{l}\text { Пшеница, Волгоградская обл., } \\
\text { поступила 07.08.2002 г. }\end{array}$ & 43,2 & 21,5 & 13,6 & 9,5 & 9,2 \\
\hline $\begin{array}{l}\text { Пшеница, Республика Марий-Эл, } \\
\text { поступила 21.08.2002 г. }\end{array}$ & 25,2 & 19,7 & 10,9 & 8,6 & 7,0 \\
\hline $\begin{array}{l}\text { Пшеница, сорт Московская 39, } \\
\text { Московская обл., } \\
\text { поступила 28.08.2002 г. }\end{array}$ & 45,6 & 20,6 & 10,8 & 9,0 & 2,9 \\
\hline
\end{tabular}




\begin{tabular}{|l|c|c|c|c|c|}
\hline $\begin{array}{l}\text { Ячмень, Волгоградская обл., } \\
\text { поступил 07.08.2002 г. }\end{array}$ & 27,0 & 9,8 & 6,4 & 5,8 & 5,7 \\
\hline $\begin{array}{l}\text { Ячмень, сорт Зерноградский-584, } \\
\text { Ростовская обл., } \\
\text { поступил 23.09.2002 г. }\end{array}$ & 11,8 & 8,6 & 8,5 & 8,5 & 8,5 \\
\hline
\end{tabular}

Как видно из таблицы 32, свежеубранное зерно имеет относительно высокую вязкость и только через три месяца хранения этот показатель стабилизируется. Т. Околелова [2006б] приходит к выводу, что вязкость зерна пшеницы и ячменя зависит от срока хранения. Причем, в большинстве случаев вязкость даже хранившегося зерна превышала европейский норматив (4-5 сПз).

С целью выявления степени и характера изменения содержания пентозанов в послеуборочный период зерна ржи нами [Исмагилов Р.Р., Ахиярова Л.М.] в 2005-2007 гг. проводились лабораторные опыты. Хранили зерно ржи сорта Чулпан 7 в течение 2-х, 4-х и 6-ти месяцев после уборки.

Исследования показали значительное снижение кинематической вязкости водного экстракта в процессе хранения. Снижение в основном происходило со дня уборки до 4-го месяца хранения. Так, у сорта Чулпан 7 (контроль) вязкость водного экстракта в 2005 году снизилась с 48,57 до 20,42 cCt, в 2006 году - с $69,84 \mathrm{cCt}$ до $21,93 \mathrm{cCt}$ и в 2007 году - с 37,58 cCt до 18,04 cCt. В последующем (к 6 месяцам хранения) изменение вязкости было незначительным. Данная закономерность в годы исследования наблюдалась у всех изучаемых сортов. Следовательно, свежеубранное зерно имеет высокую вязкость, снижение которой происходит к 4-му месяцу его хранения после уборки. Причем, к концу хранения вязкость водного экстракта у сортов несколько выравнилась и составила, например, в 2007-2008 году от 27,04 cCt (сорт Ирина) - 10,07 cCt (сорт Саратовская 7). Если разница между максимальным и минимальным значением данного показателя в начале хранения была $23,92 \mathrm{cCt}$, то в конце хранения - 16,97 cCt (2007-2008 гг.) (рисунок 12).

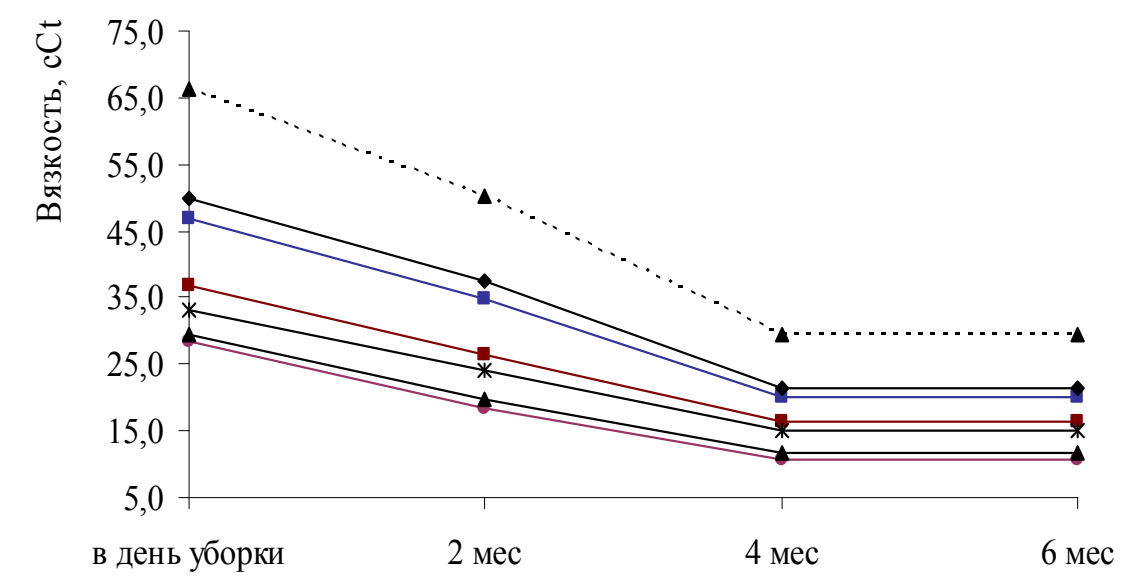

Продолжительность хранения

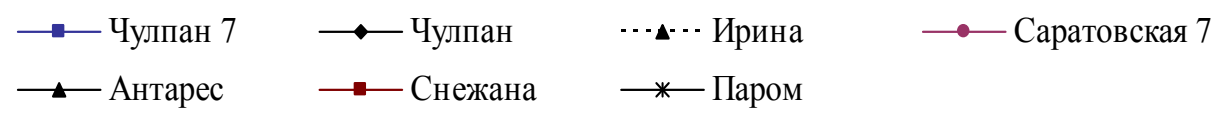


Рисунок 12. Динамика кинематической вязкости водного экстракта зерна сортов озимой ржи в процессе хранения (УНЦ Башкирский ГАУ, 20052008 гг.)

По сравнению с контрольным сортом Чулпан 7 в среднем сравнительно высокой вязкостью водного экстракта зерна озимой ржи (после 6-ти месяцев хранения) выделились сорта Ирина и Чулпан, а низкой - сорта Саратовская 7 , Антарес, Снежана и Паром. Следует указать, что зерно озимой ржи сорта Ирина остается высоковязким даже после хранения $(29,47 \mathrm{cCt})$ по сравнению с сортом Саратовская $7(10,54 \mathrm{cCt})$ и Антарес $(11,73 \mathrm{cCt})$.

За 4 месяца хранения вязкость водного экстракта зерна у сорта Чулпан 7 снизилась в 2,33 раза, Чулпан - 2,33 раза, Ирина - 2,25 раза, Саратовская 7 2,71 раза, Антарес - 2,48 раза, Снежана - 2,25 раза и у сорта Паром - 2,20 раза. Как видно из этих данных, сравнительно сильное снижение вязкости водного экстракта произошло у сортов Саратовская 7 и Антарес, в меньшей степени - у сортов Ирина, Снежана и Паром.

В процессе хранения провели анализ качества зерна разной фракции (по толщине). В результате выявили, что вязкость зерна разной фракции (крупности) в процессе хранения снижается и несколько сближаются между собой, но зерно мелкой фракции снижается в меньшей степени и остается сравнительно высоковязким и к 6-ти месяцам хранения. Так, у сорта Чулпан 7 зерно фракции 2,5-2,7 мм имело вязкость водного экстракта в день уборки 31,43 cСt и к шестому месяцу хранения снизилась до 10,66 cCt (2005-2006 г.), вязкость водного экстракта зерна фракции 2,2-2,5 мм снизилась с 48,91 сCt до $20,49 \mathrm{cCt}$, фракции 2,0-2,2 мм - c 67,14 cCt до 35,80 cCt, фракции 1,8-2,0 мм с 87,96 до 46,17 cCt. Вязкость водного экстракта зерна фракции 2,5-2,7 мм снизилась после 4-х месяцев хранения в 2,68 раза, фракции 2,2-2,5 мм - в 2,64 раза, фракции 2,0-2,2 мм - в 2,10 раза и фракции 1,8-2,0 мм - в 1,84 раза. Данная закономерность наблюдалась в годы исследования у всех изучаемых сортов.

В годы исследования после хранения наименьшей вязкостью водного экстракта всех фракций зерна выделились сорта Саратовская 7 и Антарес, а наибольшей - Ирина, Чулпан и Чулпан 7. Сорта Снежана и Паром занимали промежуточное положение.

В целом, полученные результаты указывают на то, что вязкость водного экстракта зерна сортов зависит от продолжительности хранения. Следовательно, хранение зерна озимой ржи можно отнести к эффективному приему снижения его антипитательного фактора. Причем, наиболее целесообразно хранение в течение 4-х месяцев после уборки крупной фракции зерна. Таким образом, для скармливания животным необходимо использовать зерно крупной фракции и минимум после 4-х месяцев хранения или после хранения путем сортировки зерновой массы выделять крупную фракцию для использования на корм.

Результаты исследований показывают, что существуют приемы (выбор сорта, разделение зерна на фракции, хранение), позволяющие существенно 
снизить содержание пентозанов в зерне ржи и тем самым увеличить нормы введения зерна озимой ржи в рацион кормления сельскохозяйственных животных.

\section{6. СПОСОБЫ ПОДГОТОВКИ ЗЕРНА РЖИ К СКАРМЛИВАНИЮ}

Повысить питательность зерна ржи, наряду с созданием сортов, сортировкой и хранением зерна в течение 3-4 месяцев после уборки, возможно путем подготовки его к скармливанию. Имеющиеся способы подготовки зерна ржи можно свести к двум группам: физико-механические и биотехнологические.

К физико-механическим способам подготовки зерна к скармливанию можно отнести измельчение, плющение, варку, поджаривание, экструдирование, гранулирование, микронизацию, экспандирование, обработку электроактивированными растворами, осолаживание и др. [Солошенко В.А., 1998; Стрекозов Н.И., 1998; Сагадатов Р.Р., Аллабердин И.А., 1990; Кумарин С.В., 1995; Мишуров Н.П., 2006].

В Башкирском НИИСХ провели исследования по увеличению содержания зерна ржи в рассыпных комбикормах при выращивании и откорме молодняка крупного рогатого скота. Было использовано четыре рецепта с включением 15, 70 и 80\% зерна озимой ржи. Опытные партии гранулировали на агрегате ОГМ-1,5 при температуре $120-130^{\circ} \mathrm{C}$ и давлении 3,5-4 атмосферы в прессующей камере. В процессе гранулирования в смесь добавляли 2-3\% патоки. Скармливание гранулированных комбикормов с содержанием 70-80\% зерна озимой ржи бычкам способствовало увеличению среднесуточных привесов на 13,2-15,6\% [Аллабердин И., 2006].

Имеющиеся недостатки ржи - низкие вкусовые качества и наличие антипитательных веществ можно устранить, применив баротермическую обработку корма (экструзия). В процессе экструзии происходит стремительный разогрев сырого корма до $130^{\circ} \mathrm{C}$ и сильное ее сжатие до 8 атм с последующим резким сбросом давления. В результате рвутся молекулярные связи внутри растительных клеток - происходит «взрыв» клетки. Клетчатка, частично распадаясь до сахаров, становится более усвояемой, растительные белки освобождаются от целлюлозной оболочки и переходят в разряд переваримых. Крупные молекулы белка распадаются на более мелкие цепочки аминокислот, что тоже облегчает его усвоение. Для получения 1 кг привеса экструдированного корма требуется на 25-30\% меньше, чем обычной кормосмеси. При этом сокращается время откорма, свиные туши получаются с большим содержанием мяса, сала на них меньше, чем при кормлении обычным кормом (Агрорынок, 2008). В процессе экструдирования на 60-80\% происходит клейстеризация крахмала, при этом общее его количество снижается на 15-17\%, количество сахара возрастает на 15-40\%, а декстринов увеличивается в 5-6 раз [Хазиахметов Ф.С., Шарифянов Б.Г., Галлямов Р.А., 2004; Экструкзионная технология..., 2005; Аллабердин И., 2006; Фицев А.И., Косолапов В.М., 2007$].$ Увеличение доли экструдированного зерна ржи в составе комбикормов для 
откормочных свиней с 20 до 40\% экономически оправдано. При более высокой доли зерна ржи (60-70\%) стоимость недополученной животноводческой продукции не компенсирует стоимостью сэкономленного зерна других злаковых культур при замене их рожью [Хазиахметов Ф.С., Шарифянов Б.Г., Галлямов Р.А., 2004].

В НИИСХ Северо-Востока и Кировской лугоболотной опытной станции ВНИИК провели научно-хозяйственный опыт по определению эффективности кормления экструдированным зерном озимой ржи. Для опыта сформировали четыре группы ремонтных телок в возрасте 15 месяцев по 10 голов в каждой. В течение 101 дня все животные получали основной рацион, состоящий из зеленой подкормки, сена многолетних злаковых трав и концентрированных кормов, представленных:

I группа - ячмень $100 \%$,

II группа - ячмень 70 + озимая рожь $30 \%$,

III группа - ячмень $70+$ экструдированная озимая рожь $30 \%$,

IV группа - ячмень 30 + экструдированная озимая рожь $70 \%$.

Результаты опыта показали, что включение в рационы телок зерна озимой ржи не нарушало работы желудочно-кишечного тракта. Животные в опытных группах отличались хорошим аппетитом. Функциональных нарушений в работе печени не наблюдалось. Переваримость сухого вещества рационов, ввиду их большой энергонасыщенности, была значительной и составила в I группе - 70,1, во II - 68,5, в III - 72,5, в IV - 74,9\%. В первой группе среднесуточный прирост составил 1077,2 г, во второй - 1031,6, в третьей - 1141,5 г, в четвертой - 1238,6 г [Косолапов В.М., Косолапова В.Г., 2004].

В СибНИПТИЖ в течение ряда лет на различных видах животных проводили исследования по определению эффективности разных способов подготовки ржи к скармливанию (плющение, тепловая обработка, обработка электроактивированными растворами), обеспечивающих снижение действия ее антипитательных факторов.

Сотрудниками института тепло- и массообмена НАН Республики Беларусь на основании изучения аппаратов с активными гидродинамическими режимами одновременного воздействия на зерно ряда факторов (температуры, влажности и времени обработки) было предложено использовать для тепловой обработки фуражного зерна метод встречных струй газовзвеси. Суть метода сводится к многократному управляемому соударению потоков газовзвеси, что обеспечивает значительную интенсификацию внешнего и внутреннего тепло- и массообмена при равномерном подводе тепла к каждой зерновке в режиме встречных струй. 
Влияние термовструдирования на степень декстринизации крахмала фуражного зерна

\begin{tabular}{|c|c|c|c|c|}
\hline Вид зерна & $\begin{array}{c}\text { Влажность, } \\
\%\end{array}$ & $\begin{array}{c}\text { Содержание } \\
\text { крахмала } \\
\text { в пересчете на } \\
\text { абсолютно } \\
\text { сухое веще- } \\
\text { ство, \% }\end{array}$ & $\begin{array}{c}\text { Содержание } \\
\text { углеводов, \% }\end{array}$ & $\begin{array}{c}\text { Степень } \\
\text { декстрини- } \\
\text { зации, \% }\end{array}$ \\
\hline \begin{tabular}{|l|} 
Пшеница: \\
исходная \\
вструдированная \\
\end{tabular} & $\begin{array}{l}11,7 \\
8,1 \\
\end{array}$ & $\begin{array}{l}66,31 \\
62,21 \\
\end{array}$ & $\begin{array}{c}5,37 \\
10,03 \\
\end{array}$ & $\begin{array}{c}- \\
46,47 \\
\end{array}$ \\
\hline $\begin{array}{l}\text { Тритикале: } \\
\text { исходное } \\
\text { вструдированное } \\
\end{array}$ & $\begin{array}{l}10 \\
8,2 \\
\end{array}$ & $\begin{array}{l}61,31 \\
56,37 \\
\end{array}$ & $\begin{array}{c}7,99 \\
15,78\end{array}$ & 49,37 \\
\hline $\begin{array}{l}\text { Ячмень: } \\
\text { исходный } \\
\text { вструдированный }\end{array}$ & $\begin{array}{l}10,7 \\
8,0 \\
\end{array}$ & $\begin{array}{l}60,81 \\
55,07 \\
\end{array}$ & $\begin{array}{l}5,07 \\
7,99 \\
\end{array}$ & 36,55 \\
\hline $\begin{array}{l}\text { Рожь: } \\
\text { исходная } \\
\text { вструдированная }\end{array}$ & $\begin{array}{l}11,6 \\
7,2\end{array}$ & $\begin{array}{l}60,39 \\
57,31\end{array}$ & $\begin{array}{c}8,23 \\
14,11\end{array}$ & 41,67 \\
\hline
\end{tabular}

По достижении высокой температуры и высоких межфазовых коэффициентов тепло- и массообмена, характерных для метода встречных струй, в каждой зерновке возникает нерелаксируемый градиент давления. Влага практически мгновенно переходит в пар и разрывает крупные крахмальные образования. Крахмал зерна частично переходит в декстрины и сахара, а в зернобобовых частично или полностью разлагаются вредные ингибиторы трипсина и хемотрипсина. Эта технология получила название «термовструдирование» (термическая встречно-струйная декстринизация зерна) [Шаршунов В.А., Червяков А.В., Бортник С.А., 1999].

Исследования специалистов института показали, что содержание белка в зерне после термовструдерной обработки существенно не изменяется, наблюдается лишь некоторое снижение водо- и солерастворимой фракций белка. Содержание остальных фракций не изменяется. При этом наблюдается значительное увеличение количества декстринов в обработанном зерне. Так, степень декстринизации крахмала после термовструдирования находится в пределах 36,55-49,37\% (таблица 33), что свидетельствует о высоком качестве получаемого корма [Коваленко С., 1998].

Одним из показателей пригодности зерна для кормления животных является наличие в них ингибиторов трипсина, которые могут на 50-60\% снижать продуктивность животных и вызывать гипертрофию поджелудочной железы. Как показали исследования, термовструдирование обеспечивает значительное снижение активности ингибиторов трипсина (таблица 34 ). 
Влияние термовструдирования на снижение активности ингибиторов трипсина

\begin{tabular}{|c|c|c|c|c|}
\hline Вид зерна & $\begin{array}{c}\text { Температура } \\
\text { теплоноси- } \\
\text { теля на } \\
\text { входе/выходе, } \\
{ }^{\circ} \mathrm{C}\end{array}$ & $\begin{array}{c}\text { Температура } \\
\text { зерна на } \\
\text { выходе, }{ }^{\circ} \mathrm{C}\end{array}$ & $\begin{array}{c}\text { Активность } \\
\text { ингибиторов } \\
\text { трипсина, } \\
\text { ИЕ/г } \\
\text { абсолютно } \\
\text { сухой } \\
\text { массы }\end{array}$ & $\begin{array}{c}\text { Снижение } \\
\text { активности, } \\
\%\end{array}$ \\
\hline \begin{tabular}{|l} 
Рожь: \\
исходная сухая \\
вструдированная \\
вструдированная \\
после варочной \\
машины \\
\end{tabular} & $\begin{array}{c}- \\
390 / 280 \\
375 / 230\end{array}$ & $\begin{array}{c}- \\
110\end{array}$ & $\begin{array}{r}12,35 \\
1,73 \\
\\
0,47\end{array}$ & $\begin{array}{c}- \\
86,0 \\
96,2\end{array}$ \\
\hline $\begin{array}{l}\text { Ячмень: } \\
\text { исходный неше- } \\
\text { лушенный } \\
\text { сухой } \\
\text { вструдированный } \\
\text { вструдированный } \\
\text { варенный }\end{array}$ & $\begin{array}{l}392 / 248 \\
370 / 250\end{array}$ & $\begin{array}{l}105 \\
105\end{array}$ & $\begin{array}{r}11,5 \\
1,94 \\
0,64\end{array}$ & $\begin{array}{c}- \\
83,1 \\
94,4\end{array}$ \\
\hline $\begin{array}{l}\text { Тритикале: } \\
\text { исходное } \\
\text { вструдированное }\end{array}$ & $\begin{array}{c}- \\
370 / 220\end{array}$ & $\begin{array}{c}- \\
\text { ПО }\end{array}$ & $\begin{array}{l}5,0 \\
0,5\end{array}$ & $\begin{array}{c}- \\
90,0\end{array}$ \\
\hline
\end{tabular}

В результате исследований и конструкторских разработок специалистами института тепло- и массообмена предложена технология термовструдирования и создана опытно-промышленная установка ТВ-ЗМ. Технологией предусмотрено несколько вариантов подготовки зерна: без предварительного увлажнения и подогрева, с предварительным увлажнением и подогревом, с предварительным шелушением и без него [Мишуров Н.П., 2006].

При тепловой обработке выше $120^{\circ} \mathrm{C}$ (микронизации) происходит декстринизация крахмала. Степень модификации крахмала зависит от температуры, продолжительности воздействия высокой температуры и влажности крахмала (таблица 35). Термическое воздействие повышает атакуемость крахмала амилолитическими ферментами [Повышение качества, 2001]. 
Зависимость степени декстринизаиии и клейстеризации крахмала в зерне ржи от продолжительности высокотемпературной микронизации

\begin{tabular}{|c|c|c|}
\hline Время обработки, с & Степень клейстеризации, & Содержание декстринов, \\
\hline- & 0 & 0,5 \\
\hline 25 & 4,0 & 2,4 \\
\hline 35 & 7.5 & 3,4 \\
\hline 45 & 16,7 & 4,6 \\
\hline 55 & 19,4 & 6,6 \\
\hline
\end{tabular}

На цыплятах-бройлерах определяли влияние тепловой обработки ржи (микронизации) при различных температурных режимах на выходе сырья (70$\left.75^{\circ} \mathrm{C}, 80-85,90-95^{\circ} \mathrm{C}\right)$, на интенсивность роста птицы и использование ею питательных веществ. Скармливание ржи при всех указанных режимах микронизации в количестве $30 \%$ от зерновой смеси оказало положительное влияние на интенсивность роста бройлеров и использование ими питательных веществ рационов по сравнению со скармливанием ржи в таком же количестве, но подготовленной методом холодного плющения. Так, среднесуточный прирост бройлеров на рационах с микронизированной рожью повысился на 5,3\%, а затраты корма на единицу прироста существенно снизились по сравнению с плющенным зерном ржи.

Определяли также эффективность подготовки зерна ржи к скармливанию путем дробления, обработки электроактивированным раствором (анолитом в соотношении: рожь: анолит - 1:1) и микронизации при температуре $85-90^{\circ} \mathrm{C}$. Норма ввода ржи в состав зерносмеси составляла 30\% по массе. Установлено, что потребление зерносмеси, обработанной анолитом, было выше на 6,9 и 7,2\%, чем микронизированной и дробленой соответственно. Рационы с микронизированной рожью обеспечивали более высокую переваримость сухого вещества и характеризовались лучшей конверсией корма в продукцию. Скармливание 1 т комбикорма с 30\% микронизированной ржи обеспечивало получение прироста живой массы бройлеров на 8,18 и 10,0\% больше, чем при скармливании такого же количества комбикорма с таким же содержанием ржи, подготовленной соответственно путем дробления и обработки электроактивированным раствором [Солошенко В.А., Филатов В.И., 1998].

Указанные выше физико-механические способы подготовки зерна ржи к скармливанию сельскохозяйственным животным и птице обладают несомненной эффективностью, но чрезвычайно энергоемки и требуют больших единовременных затрат на приобретение необходимого оборудования. Гораздо технологичнее использовать для нейтрализации антипитательных факторов зерна озимой ржи биотехнологические способы подготовки.

Разработаны следующие биотехнологические методы: дрожжевание, осолаживание, обработка ферментативными препаратами [Головин А.В., 1994; Кирилов М., 2001; Косолапов В.М., 2004; Сысуев А.В., 2004б; Озимая рожь, 2007]. 
Дрожжевание увеличивает содержание полноценного белка в 1,5-2 раза, значительно возрастает содержание биологически активных веществ, ферментов и витаминов. Осолаживание применяют для улучшения вкуса зерновых кормов путем перевода части крахмала в сахар под действием диастазы зерна или специально добавленного солода [Макарцев Н.Г., 1999].

Для поросят-откормочников разработан и апробирован метод биотехнологической обработки ржи, который включает в себя активацию растительных амилаз ржи при определенной влажности и температуре исходной продукции; сушку зерна ржи, ее измельчение и ввод в состав комбикормов. Эффективность обработки зерна ржи биотехнологическим методом оценивали, прежде всего, по содержанию различных форм азота. В необработанной зерне содержится 2,09\% общего, 0,27 белкового и $1,82 \%$ небелкового азота, в обработанной - соответственно 2,10; 0,14 и 1,96\%. Меньшее содержание белкового азота в обработанной ржи, чем в исходной, указывает на переход азотистых веществ от сложных органических соединений к более доступным простым метаболитам и формам их усвоения в организме животных.

Исследования на животных проводили в два этапа. Первый включал в себя физиологический опыт по изучению процессов пищеварения в тонком отделе кишечника. Первая группа из трех поросят в возрасте 90 дней получала комбикорм, не содержащий ржи, второй группе поросят-аналогов скармливали комбикорм с содержанием в нем $77 \%$ обработанной ржи. Установлено, что размеры всасывания химуса в кишечнике, служащие основным показателем интенсивности обменных процессов, у подсвинков опытной группы были на 14,5 л выше по сравнению с поросятами контрольной группы. Следовательно, произошла активизация процессов пищеварения у животных опытной группы. Схема зоотехнического опыта (второй этап исследования) включала в себя три группы помесных поросят в возрасте 60 дней. Поросят выращивали до 110дневного возраста. Средняя живая масса одной головы $-21,6$ кг. Контрольная группа в составе комбикорма не получала зерна ржи, молодняк первой опытной получал комбикорм с содержанием 40\% ржи, в том числе 30 натуральной и 10 обработанной, второй - 77\% обработанной ржи.

Среднесуточные приросты живой массы молодняка были на уровне 342360 г и соответствовали основным технологическим нормативам хозяйств, использующих собственную кормовую базу. Затраты корма на 1 кг прироста живой массы поросят второй группы были практически одинаковыми с контролем и на 4\% меньшими по сравнению с первой группой, затраты корма в которой были выше контроля на 5,1\%. Результаты исследований показали, что, применяя биотехнологический метод обработки зерна ржи, можно увеличить ее ввод в рацион свиней [Мошкутело И., Епифанов В., 2003].

В настоящее время все большее распространение получают различные ферментативные препараты, которые вводятся в составы комбикормов. Добавление фермента уменьшает вязкость содержимого кишечника и улучшает перевариваемость и усвоение корма цыплятами в рационах, содержащих зерно ржи [Patel M.B., 1980; Groot Wassing J.W., 1989]. A.I. Fengler и R.R. Marquardt 
[1988а] продемонстрировали, что добавление целлюлазы из Trichoderma virida к раствору растворимых пентозанов или водному экстракту ржи уменьшило вязкость раствора до уровня воды. Добавление целлюлазы из Trichoderma virida к ржаным рационам цыплят способствовало увеличению накопления жира и сухого вещества и уменьшило вязкость содержимого кишечника.

O.D. Friesen, W. Guenter, B.A. Rotter и R.R. Marquardt [1991] изучали оптимальные дозы ферментов (целлюлазу Trichoderma virida) для добавления в 60\%-ный ржаной рацион цыплят. Концентрации ферментов колебалось от 0,05 до 12,8 г на 1 кг корма. Добавление 3,2 г фермента на 1 кг корма способствовало улучшение усвояемости и увеличение массы цыплят на 71 и $193 \%$ соответственно. Дальнейшее повышение концентрации фермента не привело к увеличению роста цыплят.

В исследованиях M.R. Bedford, H.L. Glassen, G.L. Campbell [1991] также при добавлении пентозаназы из Trichoderma longibrachiatum до 20\% в $60 \%$-ный ржаной рацион петушков бройлеров снизилась концентрация полисахаридных комплексов и вязкость содержимого кишечника, улучшилась перевариваемость корма.

Экзогенные ферменты (привносимые с кормом) активизируются влажной средой, $\mathrm{pH}$ и температурой пищеварительного тракта, целенаправленно действуют, прежде всего, на субстрат корма, которые содержат растворимые некрахмалистые полисахариды (арабиноксиланы, $\beta$-глюканы и пектиновые соединения), обладающие большими антипитательным свойствами. Длинные молекулярные цепочки растворимых полисахаридов, соединенные $\alpha$ и $\beta$-связями, представляют собой сеть, которая улавливает воду, тем самым, повышая вязкость и замедляя прохождение корма в кишечнике. Эндогенные ферменты, секретируемые пищеварительной системой моногастричных животных, способны разрывать только $\alpha$-связи и не могут разрывать $\beta$-связи. Гидролиз некрахмалистых полисахаридов приводит к разрушению глюцидного звена, что дает доступ эндогенным ферментам к попавшим в ловушки питательным веществам рациона.

Всероссийским НИИ животноводства и Институтом биотехнологии созданы комплексные ферментные препараты - мультиэнзимные композиции (МЭК), целенаправленно действующие на природные полимеры фуражного зерна, способствуя разрушению трудноусвояемых полисахаридов и снятию «ингибирующего эффекта» на эндогенные ферменты. В целом исследования, проведенные по данной проблеме показали, что разработанные в нашей стране мультиэнзимные композиции МЭК-СХ-1, МЭК-СХ-2 и МЭК-СХ-3 оказывают положительное влияние:

- повышают переваримость и использование животными питательных веществ комбикормов с высокой удельной массой зерновых компонентов (ячменя, овса, ржи, пшеницы), пшеничных отрубей, способствуя повышению энергетической, протеиновой ценности и их продуктивного действия;

- повышают продуктивность животных (приростов живой массы, удоев молока, яйценоскости) и качество продукции;

- улучшают конверсию корма; 
- снижают стоимость кормов, расходуемых на единицу продукции, повышают рентабельность производства продуктов животноводства;

- снижают уровень заболеваний желудочно-кишечного тракта птицы, объем помета и влажность подстилки (Использование..., 1998 ; Использование..., 2004].

МЭК-СХ-1 предназначена для использования в составе комбикормов с повышенным содержанием зерна ржи, МЭК-СХ-2 - для комбикормов с преимущественным содержанием ячменя, МЭК-СХ-3 - для использования в комбикормах с пшеницей, овсом и (или) пшеничных отрубей (до 30\%).

МЭК-СХ-1 стандартизируют по амилазе (АС-900-1200 ед/г) и целлюлазе (ЦА - 180-240 ед/г). Препарат содержит также Р-глюканазу, протеазу, пентозаназу, Р-амилазу.

МЭК-СХ-2 стандартизируют по Р-глюканазе (Р-Г.А. - не менее 250 ед/г), целлюлазе (Ц.А. - 160-220 ед/г) и амилазе (АС - не менее 600 ед/г). Препарат содержит также протеазу, ксиланазу, Р-амилазу и другие ферменты.

МЭК-СХ-3 стандартизируют по ксиланазе (КсА - 1600-2000 ед/г), пектинлиазе (ПА - 1350-1700 ед/г) и Р-глюканазе (Р-ГлА - не менее 200 ед/г). Препарат также содержит амилазу, протеазу, Р-амилазу и другие ферменты.

В экспериментальных исследованиях, проведенных in vitro, установлено, что под действием комплексных ферментных препаратов усиливается гидролиз крахмала на 40-52 ${ }^{\circ}$, возрастает высвобождение редуцирующих углеводов в 1,1-1,5 раза, растворимых фракций пектинов - на 20-22\%, целлюлозы - на 6$12 \%$, гемицеллюлоз - на 11-13\%. Под влиянием МЭК увеличивается уровень растворимых пентоз в экстракте на 30-40\%.

Проведены исследования по изучению переваримости сухого вещества (CB) зерна ржи in vitro и in vivo. Установлено, что переваримость in vitro CB в контроле составила $63,9 \%$, а в опыте при использовании разных норм ввода МЭК - от 66,4 до 74,4\%; in vivo - 78,2\% в контроле и от 81 до $83 \%$ в опытных вариантах.

Мультиэнзимные композиции МЭК-СХ-1, МЭК-СХ-2 и МЭК-СХ-3 зарегистрированы в РФ за №ПВР-2-3.9/00154; ПВР-2-3.9/00155 и ПВР-23.1/00732 соответственно, сертифицировано и аттестовано их промышленное производство. Право производства мультиэнзимных композиций на основе высокопродуктивных штаммов-продуцентов ферментов Институтом биотехнологии передано ОАО «Восток» (1999 г.) и ФГУП «Бердский завод биологических препаратов» [Использование..., 2004].

Экспериментальные исследования МЭК-СХ-1 проводили на дойных коровах, откармливаемых бычках и свиньях, а также на цыплятах-бройлерах.

Учеными ВИЖа на лактирующих коровах проведено два опыта. Первый проведен на трех группах коров с продуктивностью 4500-5000 кг молока в год, из которых первая группа получала комбикорм с 40\% ржи, вторая - с 50\%, третья - комбикорм с 50\% ржи обогащенный МЭК-СХ-1. Среднесуточный удой молока, скорректированного на 4\%-ную жирность, составил соответственно по группам 20,7; 19,5 и 21,1 кг при затратах кормов на 1 кг молока 0,75; 0,79 и 0,74 ЭКЕ. 
Второй опыт проведен на коровах с продуктивностью свыше 5000 кг молока в год, в этой связи нормы ввода ржи в комбикорма были снижены. Первая группа коров получала комбикорм, без зерна ржи, животные второй группы получали комбикорм с $30 \%$ ржи, третьей - с $40 \%$ и коровам четвертой группы скармливали аналогичный комбикорм, но обогащенный МЭК-СХ-1. Среднесуточный удой 4\%-ного молока соответственно по группам составил: 26,$2 ; 25,7 ; 25,0$ и 26,6 кг при затратах комбикормов 301; 302; 304 и 297 г/л.

В производственном опыте первая группа коров получала комбикорм без зерна ржи, а вторая и третья группы - с 50\% ржи. Комбикорм для коров третьей группы был обогащен МЭК-СХ-1. Среднесуточный удой молока 4\%-ной жирности составил 16,$7 ; 16,0$ и 16,9 кг при затратах кормов 0,$93 ; 0,97$ и 0,92 ЭКЕ.

Таким образом, обогащение мультиэнзимной композицией комбикормов с высоким содержанием зерна ржи во всех случаях сопровождалось увеличением продуктивности коров: в первом опыте - на 7,6\%; во втором - на 6,2 и в производственном на 5,6\% [Кирилов М., Крохина В., 2001).

А.В. Головиным [1994] в стойловый период был проведен опыт на новотельных коровах, из которых были сформированы четыре группы животных-аналогов с удоем по предыдущей лактации около 5500 кг и жирностью $4,3 \%$. Основной рацион во всех группах был одинаковым и состоял из сена, сенажа, кормовой свеклы и травяных гранул. Недостаток питательных веществ основного рациона балансировали комбикормами из расчета 350 г на 1 л молока.

Животные первой (контрольной) группы получали комбикорм № 1, его зерновая часть была представлена ячменем и овсом. Вторая группа получала комбикорм № 2, в котором $30 \%$ яменя заменили эквивалентным количеством зерна ржи. Животные третьей опытной группы получали комбикорм № 3, содержащий $40 \%$ зерна ржи, с включением ферментных препаратов в виде мультиэнзимной композиции.

Молочная продуктивность коров первой и второй групп, выраженная как в показателях валового удоя натурального молока, так и среднесуточного удоя молока 4\%-ной жирности, практически не различалась; соответственно 2950 и 2970 кг; 26,2 и 25,7 кг. У коров третьей группы, получавших комбикорм с 40\% зерна ржи, по сравнению с контролем валовой удой натурального молока был меньше на 149 кг, или на 4,7\%, а среднесуточный удой молока 4\%-ной жирности - на 1,2 кг, или на $4,8 \%$ ниже. У коров четвертой группы, получавших комбикорм с 40\% зерна ржи, обогащенный мультиэнзимной композицией, валовой удой натурального молока и содержание в нем жира были несколько выше по сравнению с контрольной группой, что привело к увеличению количества молока $4 \%$-ной жирности (на 3,8 кг, или на $1,2 \%$ и на 187 кг, или на 6,2\% по сравнению с животными третьей группы). Не было отмечено изменение физиологического состояния коров и различие в оплодотворяемости животных. Сервис-период в первой группе составил 84 дня (индекс осеменения 1,26), во второй, третьей, четвертой группах соответственно 87 и 1,$25 ; 89$ и 1,35; 90 и $1,47$. 
Результаты опыта подтверждаются данными физиологического опыта, проведенного на трех животных из каждой группы на четвертом месяце лактации. Среднесуточный удой молока за учетный период составил 24,226,6 кг. В третьей группе коэффициент переваримости клетчатки был ниже на $5 \%$ по сравнению с контрольными животными и на $8,3 \%$ меньше, чем в четвертой группе.

Исследования показали, что коровам с продуктивностью около 5500 кг молока в год можно скармливать комбикорма, содержащие до 30\% (по массе) зерна ржи. При условии обогащения комбикорма ферментными препаратами доля зерна ржи может быть увеличена до 40\% [Головин А.В., 1994].

Сотрудниками НИИСХ Северо-Востока совместно с ОНО «Кировская лугоболотная опытная станция» Всероссийского института кормов с целью изучения эффективности скармливания плющеного зерна озимой ржи совместно с полиферментным препаратом МЭК-СХ-1 был проведен эксперимент на дойных коровах первой лактации со среднесуточным удоем 28 кг молока.

Различие в рационе кормления между группами состояло в составе концентрированных кормов и способе их подготовки. Концентрированная часть рациона контрольной группы (I группа) была представлена ячменной дертью - 7 кг (100\%). Концентрированная часть рациона коров опытных групп была составлена из расчета $30 \%$ сухого вещества ячменя (2 кг) и $70 \%$ сухого вещества плющеной (II группа) или дробленой (III и IV группы) озимой ржи (5 кг на голову в сутки). Животным второй и третьей опытных групп в состав рациона дополнительно вводили ферментный препарат МЭК-СX-1 в дозе 4 г на животное путем смешивания с зерновыми кормами. Продолжительность эксперимента 90 дней.

В целом рационы коров всех групп были сбалансированы согласно нормам ВИЖа и отвечали потребностям животных в питательных веществах. Однако рацион кормления животных контрольной группы, не содержащий в своем составе зерна озимой ржи, по концентрации обменной энергии превосходил рационы опытных групп на 9 МДж.

В результате исследований установлено, что коровы хорошо поедали корма, не испытывали недостатка в питательных веществах и не использовали ресурсы организма для поддержания жизни и производства продукции.

Биохимическое исследование крови также показало на отсутствие статистически существенных изменений изучаемых параметров. Общий белок, кальций, фосфор и сулемовая проба сыворотки крови находились в пределах физиологической нормы. Изучение качества молочной продукции коров всех групп также показало, что статистически существенного изменения в содержании жира, белка, сухого обезжиренного молочного остатка, плотности молока не происходит.

При скармливании в составе рациона животным второй группы плющеного зерна озимой ржи в количестве $70 \%$ от зерновой части концентрированных кормов отмечалась тенденция к увеличению молочной продуктивности в сравнении с другими группами (таблица 36 ). 
Молочная продуктивность животных

\begin{tabular}{|l|c|c|c|c|}
\hline \multicolumn{1}{|c|}{ Показатели } & \multicolumn{3}{|c|}{ Группа } \\
\cline { 2 - 5 } & $\begin{array}{c}\text { I } \\
\text { (контроль) }\end{array}$ & II & III & IV \\
\hline $\begin{array}{l}\text { Среднесуточный удой молока в } \\
\text { расчете на одну голову, кг: } \\
\text { натурального }\end{array}$ & 24,23 & 25,24 & 24,05 & 23,18 \\
$\begin{array}{l}\text { базисной жирности (3,4\%) в } \\
\text { начале опыта } \\
\begin{array}{l}\text { базисной жирности }(3,4 \%) \text { в } \\
\text { конце опыта }\end{array}\end{array}$ & 26,08 & 27,39 & 25,96 & 25,09 \\
\hline
\end{tabular}

Так, среднесуточный удой натурального молока во второй группе коров был выше на 4,2\%, по сравнению с контрольным вариантом, в третьей - на 4,9, в четвертой - на $8,9 \%$. В пересчете на молоко базисной жирности $(3,4 \%)$ среднесуточный удой первотелок второй группы за период эксперимента увеличился на 1,19 кг. В контроле за этот же период времени количество молока, получаемого от коровы за сутки, увеличилось на 0,64 кг, в третьей опытной группе - на 1,06 кг, в четвертой - на 0,82 кг, т.е. от коров второй группы, получавших плющеную рожь с МЭК-СХ-1, каждый день надаивали на 0,13-0,55 кг молока базисной жирности больше, чем в других группах.

Валовой надой натурального молока за период проведения эксперимента во второй, третьей и четвертой опытных группах был выше, чем в контроле на 1034, 1166 и 2101 кг соответственно.

Затраты кормов для получения 1 кг натурального молока во второй группе первотелок составили 0,73 ЭКЕ, а концентрированных кормов - 277,3 г и были ниже, соответственно, на 0,03-0,1 ЭКЕ и на 4-8\% в сравнении с контрольной, третьей и четвертой группами.

Дополнительное введение в состав рациона коров второй и третьей групп полиферментной композиции МЭК-СХ-1 в количестве 4 г/гол, привело к удорожанию суточного рациона на 3,46 руб. $(8,5 \%)$. Однако за счет лучшей переваримости плющеного зерна ржи и более высокой усвояемости питательных веществ рациона при реализации молока базисной жирности от животных второй группы была получена дополнительная прибыль. В целом же прибыль от реализации молока второй группы животных была выше на 2-18\% в сравнении с другими группами. Причем, наибольшая разница наблюдалась между второй и третьей группами первотелок, которые получали плющеную и дробленую рожь с ферментом. 
Таким образом, дополнительное введение в состав рациона мультиэнзимной композиции в количестве $0,05 \%$ от массы концентратов позволяет увеличить норму ввода плющеной озимой ржи до $70 \%$ от зерновой части концентрированных кормов [Использование ..., 2004).

На молодняке КРС учеными ВИЖ проведено два опыта: один на доращивании и второй на заключительном откорме.

В первом опыте одной группе животных скармливали комбикорм, содержащий 40\% ржи, другой - такой же, но с включением МЭК-СХ-1. Среднесуточный прирост живой массы по группам составил соответственно 830 и 930 г при затратах кормов на 1 кг прироста 8 и 7 ЭКЕ.

Второй опыт был проведен с использованием комбикорма-концентрата с $60 \%$ зерна ржи. Среднесуточный прирост животных контрольной группы, которым скармливали комбикорм без ферментных препаратов, за период опыта составил 845 г. Обогащение этого комбикорма МЭК-СХ-1 позволило повысить среднесуточный прирост живой массы до 996 г, или на 16,9\%.

В производственном опыте с использованием комбикормов, содержащих $60 \%$ зерна ржи, на заключительном откорме бычков получены аналогичные результаты. Обогащение комбикорма МЭК-СХ-1 позволило увеличить среднесуточный прирост с 856 до 1020 г, или на 19,1\%, затраты кормов снизились при этом с 10 до 8,5 ЭКЕ на 1 кг прироста [Кириллов М., Крохина В., 2001].

В Всесоюзном институте животноводства провели производственный эксперимент на трех группах свиней, откармливаемых с 29 до 110 кг живой массы. Согласно схеме опыта, животных контрольной группы кормили полнорационным комбикормом, единственным зерновым компонентом которого был ячмень. В комбикормах для подсвинков опытных групп ячмень частично заменяли рожью: животные второй группы получали комбикорм с $30 \%$ (по массе) ржи и третьей - с 40\% ржи с добавкой в него МЭК-СХ-1 в количестве $0,2 \%$ от массы комбикорма.

В целом за опыт среднесуточный прирост массы в контрольной, второй и третьей группах составил 621; 630 и 641 г., на 1 кг прироста было израсходовано 4,14; 4,08 и 4,01 кг комбикорма соответственно.

Результаты проведенного эксперимента показали, что замена $30 \%$ по массе ячменя эквивалентным количеством ржи не оказала отрицательного влияния на эффективность откорма свиней. Применение в составе комбикорма мультиэнзимной композиции позволяет увеличить норму ввода ржи до $40 \%$.

В СибНИПТИЖ на цыплятах-бройлерах было изучено влияние сбалансированного рациона с содержанием 30\% по массе зерна ржи с дополнительным введением ферментного препарата МЭК-СХ-1 из расчета 2 кг/т зерносмеси.

Установлено, что потребление зерносмеси, содержащей рожь и мультиэнзимную композицию, было на 6,9\% выше, чем без ферментов, интенсивность роста бройлеров увеличилась на 9,6\% [Солошенко В.А., Филатов В.И., 1998]. 
С учетом данных Всероссийского института животноводства (ВИЖ), Всероссийского института кормов (ВИК) и других научных учреждений, новые уточненные нормы ввода зерна ржи в составы рационов сельскохозяйственных животных представлены в таблице 37.

Таблица 37

Нормы ввода зерна ржи в комбикорма для крупного рогатого скота, свиней и птицы [Использование ..., 2004]

\begin{tabular}{|l|c|c|}
\hline \multirow{2}{*}{ Вид и группа животных } & \multicolumn{2}{|c|}{$\begin{array}{c}\text { Допустимое количество } \\
\text { от массы комбикорма, \% }\end{array}$} \\
\cline { 2 - 3 } & $\begin{array}{c}\text { без специальной } \\
\text { обработки }\end{array}$ & $\begin{array}{c}\text { с добавкой МЭК- } \\
\text { СХ-1 }\end{array}$ \\
\hline Дойные коровы с продуктивностью & & 50 \\
молока в год, тыс. кг: & 40 & 40 \\
$\begin{array}{l}\text { до 4,5 } \\
\text { до 5,5 }\end{array}$ & 30 & 40 \\
\hline $\begin{array}{l}\text { Молодняк крупного рогатого скота: } \\
\text { на доращивании } \\
\text { откорме }\end{array}$ & 30 & 60 \\
\hline Откорм свиней от 40 кг живой массы & 40 & 40 \\
\hline Взрослая птица & 30 & 25 \\
\hline Молодняк птицы & 7 & 20 \\
\hline
\end{tabular}

Следует отметить, что ферментные композиции эффективны в рационах с высоким содержанием ржи лишь при условии сбалансированности их по основным нормируемым показателям и особенно по протеину.

Согласно результатам исследований, проведенных на крупном рогатом скоте, свиньях и птице наиболее эффективной нормой ввода мультиэнзимных композиций в комбикорма является доза $0,1 \%$ по массе или 1 кг МЭК на 1 т комбикорма. Однако следует иметь в виду, что в исследованиях были использованы комбикорма с высоким уровнем лимитирующего фактора (зерно ржи, ячменя, пшеницы, овса и пшеничных отрубей). При более низких нормах ввода этих компонентов в состав комбикормов доза МЭК может быть снижена до $0,05 \%$, или до 0,5 кг на 1 т.

Мультиэнзимные композиции вводят в комбикорма и балансирующие добавки также как и другие биологически активные вещества (витамины, микроэлементы, антиоксиданты и др.) в составе премиксов.

На комбикормовых предприятиях введение МЭК в премиксы производится с помощью дозаторов, обеспечивающих точное дозирование и равномерное распределение ферментных препаратов во всей массе премикса.

При выработке комбикормов в условиях хозяйств ферментные препараты в комбикорма необходимо вводить через смесители в составе витаминноминерального премикса или отдельно, путем предварительного ступенчатого смешивания их с наполнителем. 
Премиксы готовят следующим образом: сначала в смеситель подают наполнитель в необходимом количестве, затем ферменты и биологически активные вещества, и тщательно перемешивают. Масса премикса должна составлять 0,5-1,0\% от массы обогащаемого комбикорма. Контроль за равномерностью распределения МЭК в массе корма проводят по уровню активности ферментов [Использование .., 2004].

В Производственном объединении «Сиббиофарм» разработана технология подготовки зерна ржи к скармливанию путем приготовления жидкой зерновой патоки на установках УЖК-500 и УЖК-1000 с использованием ферментного препарата «Полифермент», который был специально разработан специалистами предприятия для данной технологии. Полифермент, содержащий в своем составе ксиланазу, бета-глюканазу и целлюлазу, устраняет отрицательное влияние некрахмалистых полисахаридов зерна ржи и повышает доступность, переваримость и использование питательных веществ кормов. Содержание ржи в концентратной части рациона с помощью переработки ее в зерновую патоку можно довести до 35-40\% для откорма свиней и до $60 \%$ для крупного рогатого скота.

Установки УЖК-500 и УЖК-1000 - это биотехнологические миницеха по глубокой переработке фуражного зерна (ржи, ячменя, пшеницы, тритикале, овса), которые устанавливаются непосредственно на фермах хозяйства и позволяют повысить эффективность использования концентратов в кормлении животных. Усвояемость питательных веществ концентратов при этом повышается с 70-75\% до 90\%.

Механизм работы установок УЖК заключается в кавитационной обработке зерна, при которой разрушается оболочка растительных клеток и облегчается воздействие ферментов на кормовой субстрат. Все агрегаты установки настроены на эффективный гидролиз крахмала зерновых: это постепенный нагрев в течение определенного времени до необходимой температуры, вихревое перемешивание массы, мелкодисперсное измельчение частиц зерна для освобождения крахмала и увеличения поверхностной площади его взаимодействия с ферментами, которые содержатся в препарате «Полифермент». В жидкой зерновой патоке накапливается до $14 \%$ простых сахаров (глюкоза), тогда как без использования полифермента содержание простых сахаров не превышает $1,5 \%$.

Введение в ежесуточный рацион дойных коров 2-3 л жидкой зерновой патоки улучшает сахаропротеиновое соотношение и позволяет отказаться от применения мелассы. Здесь уместно сказать о том, что жидкая зерновая патока имеет важное преимущество перед свекловичной мелассой. При выращивании сахарной свеклы для получения максимальных урожаев применяется интенсивная технология с большим количеством удобрений, неоднократной обработкой посевов химическими пестицидами для защиты от сорняков, вредителей и болезней. В итоге в мелассе накапливаются нитраты и нитриты, небезопасные продукты разложения химических пестицидов, попадающие в молоко, вредящие здоровью животных. Зерновая патока, которая, как правило, готовится из собственного зерна, лишена этих угроз. 
Жидкая зерновая патока из ржи обладает высокой энергетической питательностью и привлекательным вкусом, что способствует улучшению поедаемости и усвоения корма и достижению эффекта «чистого корыта». Улучшение поедаемости кормов, если в них добавляется жидкая зерновая патока, отмечается повсеместно. Включение патоки в рацион животных позволяет избежать потери кормов, а это немалый резерв повышения продуктивности животных и экономии кормов [Силин М.А., 2012].

В Республике Башкортостан есть примеры эффективного использования полиферментных препаратов для повышения питательности фуража из зерна ржи. Так, в ТНВ «Урожай» Илишевского района (председатель Мухарямов А.3.) возделывают рожь на больших площадях и получают хороший урожай ржи. В стойловый период, применяя полиферментный препарат, в рацион кормления дойных коров вводят зерно ржи до 40\% зернофуража [Исмагилов Р.P., 2011], что позволяет снизить себестоимость молока.

\section{БИБЛИОГРАФИЧЕСКИЙ СПИСОК}

1. Аллабердин, И.Л. Зерно озимой ржи в комбикормах для молодняка / И.Л. Аллабердин // Животноводство России. - 2006. - № 11. - С. 52-53.

2. Аллабердин, И.Л. Ржи не надо бояться / И.Л. Аллабердин, Б. Шарифянов, Ф.С. Хазиахметов // Сельские узоры. - 1993. - №3. - С. 4.

3. Аллабердин, И.Л. Сколько ржи надо включать в комбикорма / И.Л. Аллабердин // Сельские узоры. - 1999. - №5. - С. 23.

4. Андрианова, Е.К. Влияние зерна пшеницы с разной вязкостью на гистоструктуру тонкого отдела кишечника у цыплят-бройлеров / Е.К. Андрианова, Т.М. Околелова // Научно-производственный опыт в птицеводстве: Экспресс-информация / ВНИТИП. - Сергиев Посад, 2003. - №1. - C. 7-10.

5. Ахиярова, Л.М. Продуктивность и качество зерна сортов озимой ржи в условиях лесостепи Республики Башкортостан / Л.М. Ахиярова, Р.Р. Исмагилов // Озимая рожь: селекция, семеноводство, технологии и переработка: Материалы Всероссийской науч.-практич. конф. - Екатеринбург: ГНУ Уральский НИИСХ. - 2012. - С. 129-132.

6. Бардинская, М.С. Растительные клеточные стенки и их образование / М.С. Бардинская. - М.: Наука, 1964. - 159 с.

7. Бахтизин, Н.Р. Озимая рожь / Н.Р. Бахтизин, Р.Р. Исмагилов. - Уфа, 1991. $-248 \mathrm{c}$.

8. Беркутова, Н.С. Методы оценки и формирования качества зерна / Н.С. Беркутова. - М.: Росагропромиздат, 1991. - 206 с.

9. Бишарев, А.А.. Формирование урожая и качества зерна сортов озимой ржи в условиях Среднего Поволжья / А.А. Бишарев, Н.В. Михайлов, Т.А. Горянина // Озимая рожь: селекция, семеноводство, технологии и переработка: Материалы Всероссийской науч.-практич. конф. - Екатеринбург: ГНУ Уральский НИИСХ. - 2012. - С. 121-124. 
10. Борос, Д. Перспективы увеличения использования ржи в кормлении животных и питании человека / Д. Борос // Озимая рожь: селекция, семеноводство, технологии и переработка: Материалы Международной науч.практич. конф. - Киров, 2003. - С. 183-184.

11.Булатов А.П. Корма и добавки - высокопродуктивным животным / А.П. Булатов, Н.А. Лушников, И.Н. Миколайчик // Курган: Зауралье, 2005. $328 \mathrm{c}$.

12. Бушук, В. Рожь: производство, химия и технология / В. Бушук, У.П. Кэмпбелл, Э. Древс; пер. с англ. В.И. Дашевского, Н.А. Емельяновой. - М.: Колос, 1980. - 247 с.

13. Быченкова В.В., Выпечные кондитерские изделия из ржи с высоким содержанием алкилрезорцинолов / В.В. Быченкова, В.Н. Красильников // 1 Международный конгресс Зерно и хлеб России - Санкт-Петербург, 2005. - С. 89.

14. Волкова, Н.М. Влияние длительного применения удобрений и извести в севообороте на качество зерна ржи / Н.М. Волкова // Труды ВНИИЗ. - 1971. Вып.72. - С. 83-89.

15. Гирфанов, В.К. Микроэлементы в почвах Башкирии / В.К. Гирфанов, Н.Н. Ряховская. - М.: Наука, 1975. - 172 с.

16. Голенков, В.Ф. Взаимодействие белков и углеводов ржи при замесе теста / В.Ф. Голенков // Труды ВНИИЗ. - 1964. - Вып.52. - С. 109-117.

17. Голенков, В.Ф. Изучение набухающих и растворимых в воде углеводов озимой ржи / В.Ф. Голенков, Г.Д. Траубенберг // Прикладная биохимия и микробиология. - 1966. - №2. - С. 27-37.

18. Головин, А.В. Использование ржи в комбикормах для высокопродуктивных коров / А.В. Головин // Достижения науки и техники. 1994. - №3. -С. 31-32.

19. Голубева, И. Преимущества экструдированного корма нового поколения // Агрорынок, 2008. - №2. - С. 11-12.

20. Гончаренко, А.А. Новые направления в селекции озимой ржи на качество зерна / А.А. Гончаренко // Современные аспекты адаптивного земледелия. - Йошкар-Ола, 1998. - С. 35-40.

21. Гончаренко, А.А. Современное состояние, проблемы и направления исследований по селекции озимой ржи в РФ / А.А. Гончаренко // Вопросы селекции, семеноводства и технологии возделывания озимой ржи в России: Тезисы докладов Всероссийского научно-методического совещания / Самара: Самарский НИИСХ. - 2000. - С. 3-7.

22. Гончаренко, А.А. Проблемы диверсификации зерна озимой ржи и задачи селекции / А.А. Гончаренко // Проблемы адаптивного растениеводства. Уфа, 2001. - C. 18-21.

23. Гончаренко А.А. Проблемы селекции озимой ржи в свете современных требований к качеству зерна // Зерно и хлеб России. - СанктПетербург, 2005a. - С. 94.

24. Гончаренко, А.А. Оценка хлебопекарных качеств зерна озимой ржи по вязкости водного экстракта / А.А. Гончаренко, Р.Р. Исмагилов, 
Н.С. Беркутова, Т.Н. Ванюшина, Д.С. Аюпов // Доклады Российской академии сельскохозяйственных наук. -2005 в. - №1. - С. 6-8.

25. Гончаренко, А.А. Средневзвешенная молекулярная масса водноэкстрактивных пентозанов озимой ржи и ее связь с технологическими и хлебопекарными качествами зерна / А.А. Гончаренко, А.С. Тимощенко, Н.С. Беркутова // Доклады РАСХН, 2008. - №4. - С.3-7.

26. Гончаренко, А.А. Производство и селекция озимой ржи в Российской Федерации / А.А. Гончаренко // Озимая рожь: селекция, семеноводство, технологии и переработка. - Уфа: ГНУ БНИИСХ, 2009. - С. 40-63.

27. Гончаренко, А.А. Улучшение хлебопекарных и кормовых качеств зерна озимой ржи методами селекции / А.А. Гончаренко, Н.В Цыганкова, С.В. Крахмалев, С.А. Ермаков, А.В. Макаров, Т.В. Семенова, В.Н. Точилин // Озимая рожь: селекция, семеноводство, технологии и переработка: Материалы Всероссийской науч.-практич. конф. - Екатеринбург: ГНУ Уральский НИИСХ., 2012. - C. 91-98.

28. Горелик, В.В. Основные направления селекции озимой ржи в Белоруссии / В.В. Горелик, Э.П. Урбан, Т.В. Бирюкович // Вестник Российской академии сельскохозяйственных наук. - 2004. - №1. - С. 18-20.

29. Гуняженко, И.В. Физиология растений с основами биохимии / И.В. Гуняженко. - Минск: Изд-во Высшая школа, 1985. - 207 с.

30. Гусманов, Р.У. Оценка эффективности производства зерна на кормовые цели / Р.У. Гусманов // Зерновые культуры. - 2001. - №2. - С. 6.

31. Девяткин, А.И. Рациональное использование кормов. - М.: Росагропромиздат, 1990.- 256 с.

32. Диагностика и профилактика нарушений минерального обмена у крупного рогатого скота. - М., 2005. - 48 с.

33. Доброхотов, Г.Н. Справочник зоотехника / Г.Н. Доброхотов. - 2-е изд., перераб. - М.: Колос, 1967. - 927 с.

34. Дэвис, Д. Биохимия растений / Д. Дэвис, Д. Джованелли; пер. с англ. М.: Мир, 1966. - 512 с.

35. Егоров, Г.А. Технологические свойства зерна / Г.А. Егоров. - М.: Агропромиздат, 1985. - 334 с.

36. Егоров, И. Используем ферментные препараты фирмы «НовоНордикс» / И. Егоров, Д. Супрунов, В. Чистяков // Комбикормовая промышленность. - 1997. - №8. - С. 35-36.

37. Илюхина, Л.А. Использование ржи в комбикормах для дойных коров с продуктивностью более 4-х тыс. кг молока в год / Л.А. Илюхина, С.В. Кумарин // Достижения науки и техники АПК, 1995. - №2-3. - С. 28-29.

38. Имангулов, Ш. Рекомендации по кормлению сельскохозяйственной птицы / Ш. Имангулов, И. Егоров, Т. Околелова / ВНИТИП. - Сергиев Пасад, 2000. $-67 \mathrm{c}$.

39. Имшенецкий, А.А. Микробиология целлюлозы / А.А. Имшенецкий. М.: Изд-во АН СССР, 1953. - 440 с.

40. Исмагилов, Р.Р. Зависимость хлебопекарных свойств зерна озимой ржи от гидротермических условий вегетации / Р.Р. Исмагилов, Н.Р. Бахтизин, 
У.Н. Хамитов, Т.Н. Ванюшина // Качество продукции растениеводства и приемы его повышения. - Уфа: Изд-во БашГАУ, 1998. - С. 129-132.

41. Исмагилов, Р.P. Качество и технология производства продовольственного зерна ржи / Р.Р. Исмагилов, Р.Б. Нурлыгаянов, Т.Н. Ванюшина - М.: АгриПресс, 2001. - 248 с.

42. Исмагилов, Р.Р. Пентозаны в зерне озимой ржи / Р.Р. Исмагилов, Д.С. Аюпов, Т.Н. Ванюшина // Озимая рожь: селекция, семеноводство, технологии и переработка. - Киров, 2003а. - С.137-139.

43. Исмагилов, Р.Р. Качество зерна сортов озимой ржи в условиях Башкортостана / Р.Р. Исмагилов, А.Г. Галикеев, Д.С. Аюпов // Озимая рожь: селекция, семеноводство, технологии и переработка. - Киров, 2003в. - С. 142143.

44. Исмагилов, Р.Р. Размеры и вязкость водного экстракта зерна сортов озимой ржи / Р.Р.Исмагилов, А.Г. Галикеев // Вавиловские чтения - Саратов, 20046. - С. 55-56.

45. Исмагилов, Р.Р. Изменение числа падения и содержания пентозанов в зерне озимой ржи в период его созревания / Р.Р. Исмагилов, Т.Н. Ванюшина, Д.С. Аюпов // Достижения аграрной науки - производству: Материалы 110 науч.-практич. конф. преподавателей, сотрудников и аспирантов университета. Агрономия. - Уфа: Изд-во БашГАУ, 2004в. - С. 70-72.

46. Исмагилов, Р.Р. Технология производства хлебопекарного зерна ржи / Р.Р. Исмагилов // Вестник Российской академии сельскохозяйственных наук, 2004. - №1. - C. 30-32.

47. Исмагилов, Р.Р. Вязкость водного экстракта как показатель хлебопекарных качеств зерна ржи / Р.Р. Исмагилов, Д.С. Аюпов // Пути мобилизации биологических ресурсов, повышения продуктивности пашни, энергоресурсбережения и производства конкурентоспособной сельскохозяйственной продукции. - Казань, 2005. - С. 123-124.

48.Исмагилов, Р.Р. Пентозаны ржи / Р.Р. Исмагилов, Т.Н. Ванюшина, Д.С. Аюпов. - Уфа: Изд-во БашГАУ, 2006. - 113 с.

49. Исмагилов, Р.Р. Рациональная рожь / Р.Р. Исмагилов // Сельские узоры. -2011 . - №2 - С. 30-31.

50.Исмагилов, Р.Р. Рациональная рожь / Р.Р. Исмагилов // Сельские узоры. - 2011. - №3 - С. 28.

51. Исмагилов, Р.Р. Качества зерна сортов озимой ржи в процессе хранения / Р.Р. Исмагилов, Л.М. Ахиярова, Б.Г. Ахияров // Аграрный вестник Урала. - 2011. - №3 - С. 63.

52. Исмагилов, Р.Р. Влияние гидротермических условий на содержание пентозанов в зерне озимой ржи / Р.Р. Исмагилов, А.Г. Галикеев, Л.М. Ахиярова // Озимая рожь: селекция, семеноводство, технологии и переработка: Материалы Всероссийской науч.-практич. конф. - Екатеринбург: ГНУ Уральский НИИСХ, 2012. - С. 110-114.

53. Исмагилова, Э.Р. Биогеоценоз и патология животных / Э.Р. Исмагилова // Вестник БГАУ. - 2005. - С. 26-28. 
54. Использование питательных веществ жвачными животными; пер. с нем. Н.С Гельман, под ред. А.М. Холманова. - М.: Колос, 1978. - 424 с.

55. Использование комплексных ферментных препаратов в производстве рожьсодержащих комбикормов (Рекомендации). - М.: Информагротех, 1998.$16 \mathrm{c}$.

56. Использование комплексных ферментных препаратов (мультиэнзимных композиций) при производстве комбикормов для сельскохозяйственных животных и птицы: Методические рекомендации.- М, 2004. $-23 \mathrm{c}$.

57. Калашников, А.П. Нормы и рационы кормления сельскохозяйственных животных. Справочное пособие / А.П. Калашников, В.И. Фисинин, В.В. Щеглов, Н.Г. Первов, под ред. А.П. Калашникова, В.И. Фисинина, В.В. Щеглова, Н.И. Клейменова. - 3-е изд., перераб. и доп. М., 2003. $-456 \mathrm{c}$.

58.Кедрова, Л.И. Проблемы селекции, производства и переработки зерна озимой ржи / Л.И. Кедрова, Ю.П. Савельев // Пути совершенствования научного обеспечения агропромышленного комплекса С.-В. России в рыночных условиях. - М., 1996. - С. 132-138.

59. Кедрова, Л.И. Озимая рожь в Северо-Восточном регионе России / Л.И. Кедрова. - Киров: Изд-во НИИСХ Северо-Востока, 2000. - 158 с.

60.Кедрова, Л.И. Экструдированная рожь в рационах телят / Л.И. Кедрова, В.М. Косолапов, В.Г. Косолапова // Животноводство России. - 2003. №10. - С. 20-21.

61. Кирилов, M. Эффективность мультиэнзимных композиций / М. Кириллов, В. Крохина // Комбикорма. - 2001. - №2. С. 46-47. $271 \mathrm{c}$.

62. Кобылянский, В.Д. Рожь / В.Д. Кобылянский. - М.: Колос, 1982. -

63. Кобылянский, В.Д. Перспективы селекции малопентозанной зернофуражной озимой ржи / В.Д. Кобылянский, О.В.Солодухина // Озимая рожь: Селекция, семеноводство, технологии и переработка, Уфа, 2009. - С.9396

64. Коваленко, С. Термовструдерная обработка для улучшения питательности зерна / С. Коваленко // Комбикормовая промышленность, 1998. №3. - C. 13-14.

65. Ковальский, В.В. Геохимическая экология / В.В. Ковальский. - М.: Наука, 1974. - 299 с.

66. Козьмина, Н.П. Биохимические основы улучшения качества зерна / Н.П. Козьмина. - М., 1959. - 398 с.

67. Козьмина, Н.П. Биохимия зерна и продуктов его переработки / Н.П. Козьмина, В.Л. Кретович. - М.: Заготиздат, 1950. - 375 с.

68. Кончакова, Е. Физиолого-биохимические показатели бройлеров при использовании ржи в комбикормах / Е. Кончакова // Научно-производственный опыт в птицеводстве: Экспресс-информация / ВНИТИП. - Сергиев Посад, 2002. - №2. - C. 6-9. 
69. Коробов, А.П. Влияние комбикормов с повышенным содержанием зерна ржи на продуктивность свиней на откорме / А.П. Коробов, А.А. Мишанин // Научно-технический прогресс в животноводстве России Ресурсосберегающие технологии производства экологически безопасной продукции животноводства: Материалы II Международной науч.-практич. конф. ВГНИИЖ. - Дубровицы, 2003. - Часть 1. - С. 104-105.

70. Косолапов, В.М. Использование зерна ржи в рационах молодняка КРС / В.М. Косолапов, В.Г. Косолапова, Н.К. Лаптева // Вестник РАСХН. - 2004. №1. - C. 30 .

71. Косолапов, В.М. Рожь в кормлении животных // Озимая рожь: селекция, семеноводство, технологии и переработка / В.М. Косолапов, А.И. Фицев, З.Н. Зверкова. Уфа, 2009. - С.154-157.

72. Костин, В.И. Углеводы амаранта и их практическое использование / В.И. Костин, Е.Н. Офицеров. - Ульяновск, 2001. - 178 с.

73. Кошелева, Г. Принцип действия ферментов / Г. Кошелева // Комбикорма. - 1999. - С. 38-40.

74. Краснюк, А.А. Селекция саратовской крупнозерной ржи / А.А. Краснюк // Селекция и семеноводство. - 1959. - №3. - С. 23-25.

75. Кретович, В.Л. Исследование слизей ржаного зерна / В.Л. Кретович, И.С. Петрова // Биохимия. - М., 1947. - Т.12. - Вып.2. - С. 97.

76. Кретович, В.Л. Превращение слизей при прорастании и созревании зерна ржи / В.Л. Кретович, И.С. Петрова // ДАН СССР. - М., 1948. - Т.LIX. №2. - C. 28 .

77. Кретович, В.Л. Слизи ржаного зерна и технологическое значение / В.Л. Кретович, И.С. Петрова // Биохимия зерна. - 1951. - Сб.І. - С. 145-159.

78. Кретович, В.Л. Слизи ржаной муки и их влияние на качество хлеба / В.Л. Кретович, И.С. Петрова // Труды ВНИИХП. - М., 1952. - Вып.4. - С. 120126.

79. Кретович, В.Л. Биохимия растений / В.Л. Кретович - М.: Высшая школа, 1980 - 445 с.

80. Кретович, В.Л. Биохимия зерна и хлеба / В.Л. Кретович. - М.: Наука, 1991. $-136 \mathrm{c}$.

81. Крохина, В.А. Комбикорма, кормовые добавки и ЗЦМ для животных (состав и применение). Справочник / В.А. Крохина, А.П. Калашников, В.И. Фисинин, Н.А. Смекалов, И.В. Хаданович. - М.: Агропромиздат, 1990. $304 \mathrm{c}$.

82. Куватов, Д.М. Биотехнология кормопроизводства / Д.М. Куватов, В.Л. Касперович, А.П. Иванова. - Уфа: Гилем, 2003. - 196 с.

83. Культурная флора СССР / В.Д. Кобылянский, А.Е. Корзун, А.Г. Катерова, Н.С. Лапиков, О.В. Солодухина. - Том II, часть 1. Рожь; под ред. В.Д. Кобылянского. - Л.: Агропромиздат, 1989. - 368 с.

84. Кумарин, С.В. Добавка способствующая повышению эффективности использования ржи коровами / С.В. Кумарин // Достижения науки и техники АПК, 1995. - №1. - С.35-36. 
85. Леснов, А.П. Биотехнологии - будущее в кормопроизводстве / А.П. Леснов // Кормление сельскохозяйственных животных и кормопроизводство. - 2006. - №2. - С. 74-75.

86. Мазник, А.П. Справочник по комбикормам / А.П. Мазник, 3.И. Хазина - М.: Колос, 1982. - 192 с.

87. Мачихина, Л. Составляющие системы хранения зерна / Л. Мачихина, Л. Алексеева, Л. Львова // Комбикорма. - 2006. - №7. - С. 55-57.

88. Методические рекомендации ВНИИЗ // Методы и приборы для определения качества заготовляемого в переработку зерна. - М., 1983. -210 с.

89. Микроэлементозы сельскохозяйственных животных в Башкирии. Уфа: Башкирское книжное издательство, 1967. - 178 с.

90. Мишуров, Н.П. Перспективные технологии тепловой обработки комбикормов / Н.П. Мишуров. - М.: Росинформагротех, 2006. - 84 с.

91. Мосолов, В.В. Протеолитические ферменты / В.В. Мосолов. - М.: Наука, 1971. - 135 с.

92. Мотовилов, К.Я. Экспертиза кормов и кормовых добавок: Учебносправочное пособие / К.Я. Мотовилов, А.П. Булатов, В.М. Позняковский, Н.Н. Ланцева, И.Н. Миколайчик. - Новосибирск: Сиб. унив. изд-во, 2004. - 303 c.

93. Никитин, Н.И. Химия древесины и целлюлозы / Н.И. Никитин. - М.: AH CCCP, 1962. $-212 \mathrm{c}$.

94. Нормы и рационы кормления сельскохозяйственных животных: Справочник. М.: Агропромиздат, 1985.-352 с.

95. Нортроп, Д. Кристаллические ферменты / Д. Нортроп, М. Кунитц, Р. Херриотт. - М.: Колос, 1950. - 204 с.

96. Нуртдинов, М. Полиферментный препарат в комбикормах с рожью / М. Нуртдинов // Комбикорма. - 2006. - №4. - С. 63.

97. Обыденова, Л.А. Формы соединений железа в почвах Удмуртской Республики / Л.А. Обыденова, Е.А.Панкратова, В.П. Ковриго // Эффективность адаптивных технологий: Материалы нау.-произв. конф. - Ижевск: Изд-во ИжГСХА, 2003. - С. 91-96.

98. Озимая рожь. Возделывание, использование на пищевые, кормовые и технические цели. - М.: ФГНУ «Росинформагротех», 2007. - $172 \mathrm{c.}$

99. Околелова, Т.М. Новые возможности использования ржи в комбикормах для бройлеров / Т.М. Околелова, Л. Криворучко, Д. Бадаева, С. Молоскин // Комбикорма. - 2001а. - №1. - С. 51-52.

100. Околелова, Т.М. Рожь вместо пшеницы в комбикормах для птицы / Т.М. Околелова // Животноводство России. - 2001б. - №5. - С. 16-18.

101. Околелова, Т.М. Корма и ферменты / Т.М. Околелова, А.В. Кулаков, С.А. Молоскин, Д.М. Грачев. - Сергиев Посад, 2001в. - 111 с.

102. Околелова, Т.М. Что полезно знать, работая с пшеничной рецептурой комбикорма / Т.М. Околелова, Е. Кончакова // Комбикорм. - 2002. - №6. - С. 45-46.

103. Околелова, Т.М. Вязкость пшеницы и ячменя / Т.М. Околелова, Е. Кончакова // Комбикорма. - 2006а. - №7. - С. 61-62. 
104. Околелова, Т.М. Резервы экономии кормов / Т.М. Околелова // Животноводство России. - 2006б. - №8. - С. 12-13.

105. Павлов, А.Н. Повышение содержания белка в зерне / А.Н. Павлов. - М.: Наука, 1984. - 119 с.

106. Перминова, И.Г. Влияние различных севооборотов на окупаемость удобрений на дерново-подзолистой суглинистой почве / И.Г Перминова, А.С. Башков, Г.П. Дзюин // Эффективность адаптивных технологий: Материалы науч.-произв. конф. - Ижевск: Изд-во ИжГСХА, 2003. - С. 130-135.

107. Пестов, В. Экструзионная установка для крахмалсодержащих продуктов / В. Пестов, В. Бабушкин, Е. Славнов, А. Судаков, В. Коробов, В. Ситников, Н. Морозков // Комбикорма. - 2006. - №3. - С. 31-32.

108. Плешков, Б.П. Биохимия сельскохозяйственных растений Б.П. Плешков. - 4-е изд., доп. и перераб. - М.: Колос, 1980. - 495 с.

109. Плешков, Б.П. Биохимия сельскохозяйственных растений Б.П. Плешков. - 5-е изд., доп. и перераб. - М.: Агропромиздат, 1987. - 494 с.

110. Повышение качества фуражного зерна - высокотемпературная микронизация. - М.: ДеЛи принт, 2001. - 35 с.

111. Приезжева, Л.Г. Изменение белкового комплекса зерна озимой ржи при созревании / Л.Г. Приезжева, В.Ф. Голенков, В.М. Гильзин // Прикладная биохимия и микробиология. - М., 1970а. - Т.6. - Вып.1. - С. 26-31.

112. Приезжева, Л.Г. Состав слизистых веществ, выделенных из зерна ржи разной степени зрелости / Л.Г. Приезжева, В.Ф. Голенков // Прикладная биохимия и микробиология. - М., 1970б. - Т.6. - Вып.5. - С. 574-577.

113. Приезжева, Л.Г. Взаимосвязь биохимических и технологических свойств зерна озимой ржи / Л.Г. Приезжева, В.Ф. Голенков, И.А. Панкратьева // Труды ВНИИЗ. - М., 1971. - Вып.71. - С. 83-93.

114. Прокошев, В.В. Калий и калийные удобрения / В.В. Прокошев, И.П. Дерюгин. - М.: Ледум, 2000. - 185 с.

115. Пшеница и оценка ее качества. - М.: Колос, 1968. -496 с.

116. Раковска, М. Полисахаридный белковый комплекс зерна ржи: переваривание и усвоение животными с однокамерным желудком / М. Раковска, Р. Купец, А. Мадей // Селекция ржи: Материалы симпозиума ЕУКАРПИА. - Л., 1990. - С. 143-150.

117. Рухлядева, Д.М. Технологический контроль спиртового производства / Д.М. Рухлядева. - М.: Пищевая промышленность, 1974. - 230 с.

118. Сагадатов, Р.Р. Использование озимой ржи на корм скоту / Р.Р. Сагадатов, И.Л. Аллабердин. - Уфа, 1990. - 4 с.

119. Скворцов, Е.В. Применение методов ВЭЖХ для оценки кормовых и технологических качеств ржи / Е.В. Скворцов // Нетрадиционные природные ресурсы, инновационные технологии и продукты. - М., 2004. - Вып.11, Ч.2. C. 52-56.

120. Силин М.А. Ценный кормовой продукт из зерна ржи // Кормопроизводство, 2012.-№3- С.44.

121. Смирнов, В.И. Пектолитические ферменты микроорганизмов / В.И. Смирнов, В.В. Котелов. - Кишинев, 1971. - 35 с. 
122. Солошенко, В.А. Рожь в комбикормах для животных / В.А. Солошенко, В.И. Филатов, В.А. Рогачев, С.В. Егоров, В.Т. Калюжнов, С.М. Подъяблонский, С.А. Юргин // Зоотехния. - 1998. - №9. - С. 17-18.

123. Сысуев, А.В. Приоритеты научных исследований по производству и переработке зерна озимой ржи / А.В. Сысуев // Вестник Российской академии сельскохозяйственных наук. - 2004а. - №1. - С. 12-14.

124. Сысуев, А.В. Технология плющения ржи / А.В. Сысуев, П. Савиных, Р. Русаков, И. Заболотских // Комбикорма. - 2004б. - №6. - С. 17 18.

125. Теняев, А. Ронозим WX - ферментный препарат для пшеничных рационов / А. Теняев // Комбикорма. - 2002. - №4. - С. 39-40.

126. Технология консервирования плодов, овощей, мяса и рыбы / Б.Л. Флауменбаум, А.А. Бровченко, под ред. Б. Л. Флауменбаума. - 2-е изд., перераб. и доп. - М.: Колос, 1993. - 320 с.

127. Тимощенко, А.С. Весовой метод определения содержания пентозанов в зерне озимой ржи / А.С. Тимощенко, А.А. Гончаренко // Доклады Российской академии сельскохозяйственных наук. - 2004. - №4. - С. 8-11.

128. Тимощенко, А.С. Адаптация роторного визкозиметра к определению относительной вязкости водного экстракта зернового шрота озимой ржи / А.С. Тимощенко, А.А. Гончаренко, Е.Н. Лазарева // Сельскохозяйственная биология, 2008. - №5. - С. 110-115.

129. Тиунов, А.Н. Озимая рожь / А.Н. Тиунов, К.А Глухих, О.А. Хорькова. - М.: Колос, 1969. - 392 с.

130. Тишенков, П.И. Ферментные системы для изменения содержания пентозанов в зерне ржи / П.И. Тишенков // Кормление сельскохозяйственных животных и кормопроизводство. - 2006. - №5. - С. 23.

131. Томмэ, М.Ф. Аминокислотный состав кормов / М.Ф. Томмэ, Р.В. Мартыненко. - М.: Колос, 1972. - 288 с.

132. Третьяков, Н.Н. Физиология и биохимия сельскохозяйственных растений / Н.Н. Третьяков, Е.И. Кошкин, Н.М. Макрушин, Н.Н. Новиков, под ред. Н.Н. Третьякова. - 2-е изд. - М.: Колос, 2005. - 656 с.

133. Удалова, Э.В. Ферменты для рожьсодержащих комбикормов / Э.В. Удалова // Комбикормовая промышленность. - 1994. - №6. - С. 13-14.

134. Удалова, Э.В. Необходимые ферменты для рожьсодержащих комбикормов / Э.В. Удалова, Т.М. Околелова // Комбикормовая промышленность. - 1995. - №6. - С. 18-19.

135. Урбан, Э.П. Рожь в зерновом хозяйстве Республики Белоруссии / Э.П. Урбан // Сельскохозяйственный вестник. - 2002. - №3. - С. 5-6.

136. Урбан, Э.П. Основные направления и результаты селекции озимой ржи в Республике Беларусь / Э.П. Урбан // Озимая рожь: селекция, семеноводство, технологии и переработка. - Киров, 2003. - С. 28-30.

137. Фатыхов, И.Ш. Озимая рожь в Предуралье / И.Ш. Фатыхов. Ижевск: Шеп, 1999. - 209 с. 
138. Фисинин, В.И. Кормление сельскохозяйственной птицы / В.И. Фисинин, И.А. Егоров, Т.М. Околелова, Ш.А. Имангулов. - Сергиев Посад, 2000. - С. 297-329.

139. Фицев, А.И. Зоотехническая оценка использования ржи в рационах сельскохозяйственных животных / А.И. Фицев, В.М. Косолапов // Кормопроизводство. - 2007. - №1. - С. 27-30.

140. Хазиахметов, Ф.С. Занимательное кормление животных / Ф.С. Хазиахметов. - Уфа: Скиф, 2001. - 256 с.

141. Хазиахметов, Ф.С. Нормированное кормление сельскохозяйственных животных / Ф.С. Хазиахметов, Б.Г. Шарифянов, Р.А. Галлямов. - Уфа: Изд-во БГАУ, 2004. - 262 с.

142. Хохрин, С.Н. Кормление сельскохозяйственных животных / С.Н. Хохрин. - М.: Колос, 2004. - 692 с.

143. Цитович, И.К. Химия с сельскохозяйственным анализом / И.К. Цитович. - М.: Колос, 1974. - 527 с.

144. Цыперович, А.С. Ферменты / А.С. Цыперович. - Киев, 1971. C. $257-267$.

145. Черкасова, С. Новые возможности в кормлении животных и птицы / С. Черкасова // Сельскохозяйственный вестник. - 2001. - №4. - С. 7-8.

146. Шаршунов, В.А. Новые технологии углубленной обработки зерна при производстве комбикормов / В.А. Шаршунов, А.В. Червяков, С.А Бортник. // Достижения науки и техники АПК, 1999. - №5. - С. 30-33.

147. Щербаков, В.Г. Биохимия / В.Г. Щербаков, В.Г. Лобанов, Т.Н. Прудникова, А.Д. Минакова; под ред. В.Г. Щербакова - 2-е издание, перераб. и доп. - СПб.: ГИОРД, 2003. -440 с.

148. Щеглов, В.В. Корма: Приготовление, хранение, использование: Справочник. / В.В. Щеглов, Л.Г. Боярский. - М.: Агропромиздат, 1990.- 255 с.

149. Экструзионная технология для производства комбикормов // Комбикорма, 2005. - С. 43.

150. Эрнст, Л. Ферменты улучшают переваривание клетчатки / Л. Эрнст, Г. Лаптев // Животноводство России. - 2006. - №10. - С. 36-37.

151. Яхин, А. Энзимы фирмы «Интервет» в комбикормах с рожью / А. Яхин, М. Кирилов, В. Терентьев, Р. Бьюлинг // Комбикорма. - 2000. - №6. C. 48 .

152. Alexander, D. Com breeding and Genetics in Corn, culture, processing product / D. Alexander, J. Dubley, P.G. Greech // Avi Publisching Co., Westport, Conn., 1970. - P. 28-35.

153. Annison, G. Carbohydr. Polym / G. Annison, M. Chost, N.W. Cheetham, 1992, V.19. - P.151.

154. Antoniou, T. Influence of Rye Pentosans on the Growth of Chicks / T. Antoniou, R.R. Marquardt // Poultry Sciense, 1981. - V. 60. - P. 1898-1904.

155. Antoniou, T. Influence of Rye Pentosans on the Growth of Chicks / T. Antoniou, R.R. Marquardt // Poultry Sci., 1981. - V. 60. - P. 1898-1904. 
156. Antoniou, T. The utilization of rye by growing chicks as influeced by calcium, vitamin $\mathrm{D}_{3}$, fat type and level / T. Antoniou, R.R. Marquardt, R. Misir // Poultry Sci., 1980. - V. 59. - P. 758-769.

157. Aspinall, G.O. Structural chemistry of the hemiceluloses, Advan / G.O. Aspinall // Carbohydrate Chem., 1959. - V.14. - P. 429-468.

158. Bacic, A. Lhemistry of the hemicelulo $\beta-\mathrm{D}$-glucan in the endosperm cell - walls of wheat / A. Bacic, B.A. Stone // Calbohydr. Res, 1980. - P. 372.

159. Baker, J.G. The pentosans of wheat flour / J.G. Baker, H.K. Parker, M.D. Mize // Cereal Chem., 1943 - V. 20. - P. 267-280.

160. Baker, J.G. Supercentrifugates from dough / J.G. Baker, H.K. Parker, M.D. Mize // Cereal Chem., 1946 - V. 23. - P. 16-20.

161. Bechtel, W.G. Staling studies of bread made with flour fractions. III. Effect of crumb moisture and of tailings starch / W.G. Bechtel, D.F. Meisner // Cereal Chem., 1954 - V. 31. - P. 176-181.

162. Bedford, M.R. The Effect of Pelleting, Salt and Pentosanase on the Viscosity of Intensinal Contens and the Performance of Broilers Fed Rye / M.R. Bedford, H.L. Glassen, G.L. Cambell // Poultry Sci., 1991 - V. 70. - P. 571577

163. Bengtsson, S. Isolation and chemical characterization of water - soluble arabinoxylans in rye grain / S. Bengtsson, P. Aman // Carbohydr. Polym., 1990. V.12. - P. 154-159.

164. Boros, D. Extract viscosity asan Indirect Assay Far water - soluble pentosan Content in Rye / D. Boros, R.R. Marguardt, B.A. Slominsky, W. Guenter // Cereal Chem., 1993. - V. 70. - №5. - P. 575-580.

165. Cole, E.W. Jsolation and chromatographic fractionation of hemicelluloses from wheat flour / Cole, E.W. // Cereal Chem., 1967 - V. 44. - P. 411.

166. Delcour, J.A. Physico-Chemical and Functional Properties of Rye Nonstarch Polysaccharides. I. Colorimetric Analysis of Pentosans and Their Relative Monosaccharide Compositions in Fraktionated (Milled) Rye Products. / J.A. Delcour, S. Vanhamel, C. De Geest // Cereal Chem., 1989a - V. 66. - №2. - P. 107-111.

167. Delcour, J.A. Physico-Chemical and Functional Properties of Rye Nonstarch Polysaccharides. I. Colorimetric Analysis of Pentosans and Their Relative Monosaccharide Compositions in Fraktionated (Milled) Rye Products / J.A. Delcour, S. Vanhamel, C. De Geest // Cereal Chem., 1989b - V. 66. - №2. - P. 107-111.

168. Drews, E. Bread baking and other uses aroun the World. In: Bushuk W. Rye: Produktion, chemistry and technology / E. Drews, W. Seibel // AACC St. Paul MN, 1976. - P. 127-174.

169. Ewald, C.M. The arrangement of branchings in an arabino-xylan from wheat flour / C.M. Ewald, A.S. Perlin // J. Can.Chem., 1959 - V. 37. - P. 1254-1259.

170. Fengler, A.I. Water-soluble pentosans from rye: I. Isolation, partial purification and charakterization / A.I. Fengler, R.R. Marguardt // Cereal Chem., 1988a- V. 65. - P. 291. 
171. Fengler, A.I. Water-soluble pentosans from rye: II. Effects on rate of dialysis and on the retention of nutrients by the chick / A.I. Fengler, R.R. Marguardt // Cereal Chem., 1988b. - V.65. - P. 298-302.

172. Fengler, A.I. Improvement in nutrient retentional and changes in exereta viscosities in chickens fed rye - containing diets supplemented with fungal enzymes, sodium tauzochaulute and penicillin / A.I. Fengler, J.R. Panclic, R.R. Marguardt // Can. J. Anim. Sci., 1988c. - V. 68. - №2. - P.483-491.

173. Fernandes, R. Fractionation of chick growth depressing factor from rye / R. Fernandes, E. Lucas, J. McGinnis // Poultry Sci., 1973 - V. 52. - P. 252-259.

174. Ford, L.H. The polysaccharide associated with $\beta$-amylase / L.H. Ford, S. Peat // J. Chem. Soc., 1941. - P. 856-864.

175. Freemach, M.E. The gums of the cereal grains / M.E. Freemach, R.A. Cortner // Cereal Chem., 1932 - V. 9. - P. 506-518.

176. Friedrich, W. Der Warmerprozep zur behandiung von komponenten und Mischungen seine wirkung auf Narhrstoffe und Tier / W. Friedrich // Die Muble Mischfuttertechnic. 1975. - V. 112. - №11. - P. 143-145.

177. Friesen, O.D. The Effekt of enzyme supplementation on the nutritive value of rye grain (Secale cereale) for the young broiler chick / O.D. Friesen, W. Guenter, B.A. Rotter, R.R. Marquardt // Poultry Sci., 1991. - P. 501-508

178. Frincher, C.B. // J.Inst. Brew., 1975, V. 81. - P. 116.

179. Frincher, C.B. Stone B.A. In "Advances In Cereal Science and Technology" / C.B. Frincher, B.A. Stone // Ed.: Pomeranz Y. (AACC, Minnesota), 1986 - V. 8. - P. 207.

180. Gan, Y.T. Extract viscosity of winter rye: variation with precipitation and temperature / Y.T. Gan, J.G. McLeod, G.J. Scoles, G.L. Campbell // Can .J. Plant Sci., 1997. - V.77. - P. 555-560.

181. Gan, Y.T. Genetic and environmental influence on extract viscosity of winter rye / Y.T. Gan, J.G. McLeod, G.J. Scoles, G.L. Campbell // Plant Breed. Seed Sci., 1996a. - V.40. - P. 93-102.

182. Gan, Y.T. Extract viskosity of winter rye: heritabillity and genetic correlation to kernel characters / Y.T. Gan, J.G. McLeod, G.J. Scoles, G.L. Gampbell // Plant Breed. Seed Sci., 1996b. - V.40. - P.103-112.

183. Gan, Y.T. Relationship between extract viscosity and kernel size in winter rye / Y.T. Gan, I.G. McLeod, G.I. Scoles, G.L. Campbell // Can. J. of Plant Sci., 1998. - V. 78 - №3. - P. 423-427.

184. Geissman, T.. - Lebensm. Wiss. Technol,1973a, V. 6. - P. 59.

185. Geissman, T.. - Cereal Chem.,1973b, V. 50. - P. 414.

186. Gilles, K.A. Studies on the gumms derived from barley flour, wheat flour, and fresh and stale bread / K.A. Gilles // Dissertation Abstr., 1954 - V. 14. - P. 459-460.

187. Gilles, K.A. Smith F. The carbohydrates of the Cramineae/ III. Anote on the hature of wheat gum / K.A. Gilles, F. Smith // Cereal Chem., 1954. - V. 31. - P. 488-489. 
188. Gilles, K.A. The carbohydrate of the Cramineae. VI. The nature of the water-soluble polisacharides of the flour of wheat (Triticum vulgare) / K.A. Gilles, F. Smith // Cereal Chem., 1956. - V.33. - P. 29-37.

189. Gilles, K.A. The carbohydrates of the Cramineae. XI. The contitution of the water-soluble polysaccharides derived from bread crumb / K.A. Gilles, W.F. Geddes, F. Smith // Cereal Chem., 1961 - V. 38. - P. 229-240.

190. Glendenning, K.A. Separation of starch and gluten / K.A. Glendenning, D.E. Wright / Problems in wheat starch manufacture arising from flour Pentosans // Can. J. Research, 1950 - V. 28F. - P. 390-400.

191. Gontzea, I. Natural anti nutritive substances in food stuffs and forages. K. Karger. Basel (Switzerland) / I. Gontzea, P. Sutzescu. - 1968. - 115 p.

192. Groot Wassing, J.W. Fraktionation of crude pentosanase (arabinoxylanase) for improvement of the nutritional value of rye diets for broiler chickens / J.W. Groot Wassing, G.L. Campbell, H.L. Classen // J. Food Agri., 1989. V. 46. - P. 289-300.

193. Hashimoto, S. Cereal pentosans: Their ensimatin and significance. I. Pentosans in wheat and milled wheat products / S. Hashimoto, M.D. Shogren, Y. Pomeranz // Cereal Chem., 1987. - V. 64. - P. 30.

194. Hay, J.C. The distribution of phytic acid in wheat and a preliminary study of some of the calcium salts of this acid / J.C. Hay // Cereal Chem., 1942. V. 19. - P. 326-333.

195. Hemicellulose degradation in the ruminant // Carbohydrate research in plants and animals in Landbouwhogesool Wageningen the Netherlands miscellaneous Papers R., 1976. - P. 14-37.

196. Henri, R. Y. Pentosans and $(1 \rightarrow 3),(1 \rightarrow 4)-\beta$ - glucan concentrations in endosperm and whole grain of wheat, barley, oats and rye / R. Y. Henri // J. Cereal Sci, 1987 - V. 6. - P. 253.

197. Izydorczyk, M.S. // J. Cereal Sci., 1990 - V.11. - P. 153.

198. Jackson, G.M. Effect of endogenoys phenolic acids on the mixind properties of wheat flour dough / G.M. Jackson, R.C. Hoseney // J.Cereal Sci., 1986 V. 4. - P. 76.

199. Jacobsen, J.V. The structure and composition of aleuron grains in the barley aleurone layer / J.V. Jacobsen, R.B. Knox, N. A. Pyliotis // Planta (Berlin). 1971. - V.101. - P. 189-209.

200. Janicki, I. Uber den Lysingehalt und den einiger anderer Aminosauren im polnischen Weizen und Roggen. Qual. / I. Janicki // Plant material Veget. - 1963. - V.10 - №4. - P. 235-254.

201. Jelaca, S.L. Hlynka I. Water-binding capacity of wheat flour crude pentosans and their relation to mixing characteristics of dough / S.L. Jelaca, I. Hlynka // Cereal Chem., 1971 - V. 48. - P. 211.

202. Jochansson, H. Undersoeknigar oever vattenloesliga pentosaaners sammansaettning I mioel och degar av vete samt pentosanernas inverkan pa knadningsstabiliteten under degutvecklingen / H. Jochansson, O. Hall, E. Sellergen, L. Thulin // Sveriges Utsaedesfoerenings Tidskrift, 1971 - V. 81. - P. 282-301. 
203. Karlsson, R. Natural anti substances in food forages / R. Karlsson // Sveriges Utsadesforenings Tidskrift., 1988a. - V. 98. - P. 225-234.

204. Karlsson, R. Pentosans in rye / R. Karlsson // Sveriges Utsadesforenings Tidskrift. - 1988b. - V. 98. - P. 213-225.

205. Kent-Jones, D.W. Modern cereal chemistry, 6th ed / D.W. Kent-Jones, A.J. Amos. // Food Trade Press Ltd: London, 1967. - P. 730.

206. Kim, S.K., D'Appolonia B.L. Note on a simplified procedure for the purification of wheat-flour pentosans / S.K. Kim, B.L. D'Appolonia // Cereal Chem., 1976 - V. 53. - P. 871.

207. Kulp K. Enzymolysis of pentosans of Wheat Flour// Cereal Chem. 1967, V. 45. - P. 339-351.

208. Laporte, J. Inhibitor action of rice, oats, maize, barley, wheat, rye and buck wheat flours on certain proteolytic enzymes of the pancreas C.R. / J. Laporte, J. Tremolieres // Soc. Biol. - 1962. - №156. - P. 1261-1263.

209. Lui, N.S. Isolation of globoids from cotton seed aleurone grain / N.S. Lui, A.M. Altschul // Arch. Biochem., 1967. - V.121. - P. 678-684.

210. MacAuliffe, T. Variable rachitogenic effects of grain and alleviation by extraction or supplementation with vitamin $\mathrm{D}_{3}$, fat and antibiotics / T. MacAuliffe, A. Pietraszek, McGinnis // Poultry Sci., 1976 - V. 55. - P. 2142-2147.

211. Madl, R.L. Trypsin and chymotrypsin inhibitors of triticale / R.L. Madl, C.C. Tsen. Abstr., 58th Annu. Mtg., St. Louis. Mo.: p. 78. Amer. Ass. Cereal Chem.: St. Paul. Minn, 1973. - V. 21. - P. 182-189.

212. Madl, R.L. Trypsin and chymotrypsin inhibitors of triticale / R.L. Madl, C.C. Tsen. // Triticale: First man-made cereal, ed. By C. C. Tsen: Amer. Ass. Cereal Chem.: St. Paul. Minn, 1974. - P. 168.

213. Mahlkow, K. Roggen ist billig: Mehr in die Ration? / K. Mahlkow // Top agrar, 2005. - №10. - P. 12-13.

214. Mares, D.J. Studies on wheat endosperm. I. Chemical composition and u trastructure of the cell walls / D.J. Mares, B.A. Stone // Aust. J. Biol. Sci., 1973a. V. 26. - P. 793.

215. Mares, D.J. Studies on wheat endosperm. II. Properties of the wall components and studies on their organisation in the wall / D. J. Mares, B. A. Stone // Aust. J. Biol. Sci., 1973b. - V. 26. - P. 813.

216. Marquardt, R.R. The retention of nutriens by chicks fed rye diets supplemented with amino acids and penicillin / R.R. Marquardt, A.T. Ward, R.Misir // Poultry Sci. 1979. - V. 58. - P.631-640.

217. McCleary, B.V. Enzymic modification of plant polysaccharides / B.V. McCleary // Jnt. J. Biol. Macromol, 1986. - V. 8. - P. 349.

218. Meredith, W.O.S. Freepentoses in malt extracts and worts / W.O.S. Meredith // Cereal Chem., 1957. - V. 34. - P. 246-251.

219. Meuser, F. Non-starch polysaccharides / F. Meuser, P. Suckow // Pages 42-61 in: Chemistry and Physics of Baking. J.M.V. Blanshard, P.J.Fraizier, T.Galliard, eds Royal Society of Chemistry, Burlington House. - London, 1986.

220. Meyer, K.H. Recherches sur amidon et amylopectin / K.H. Meyer, P.G. Bemfeld // Helv. Chem. Acta., 1940. - V. 23. - №5. - P. 875-890. 
221. Michniewicz, J. Water-insoluble pentosans of wheat: composition ans some physical properties / J. Michniewicz, C.G. Biliaderis, W. Bushuk // Cereal Chemistry, 1990. - V. 67. - P. 434-439.

222. Miller, D.F. Compositions of cereal grains and foradet / D.F. Miller // Nat. Acfl. Sci. Nat. Res. Counl. Waschington D.C., 1958. - P. 114-129.

223. Misir, R. Factors affecting rye (Secale cereale L.) utilization in growing chicks. IV. The influence of autoclave treatment, pelleting, water exstraction and penicillin supplementation / R. Misir, R.R. Marquardt // Gan. J. Sci., 1978. - V. 58. P. 731-742.

224. Montgomerry, R. The carbohydrates of the Cramineae. VII. The constitution of a water-soluble hemicellulose of the endosperm of wheat (Triticum vulgare (aestivum)) / R. Montgomerry, F. Smith // J. Am. Chem. Soc., 1955. - V. 77. - P. 325-328.

225. Montgomery, R. Areview of carbohydrates of Wheat and other cereal grains / R. Montgomery, F. Smith // J. Agr. Food Chem., 1959 - V. 4. - P. 716-720.

226. Moore, A.M. Factors Affecting the Viscosity of Flour - Water Extracts / A.M. Moore, R.S. Hoseney // Cereal Chem., 1990. - V. 70. - №1. - P. 78-80.

227. Moran, E.T. The feeding value of rye for the growing chick. Effect of enzyme supplements, antibiotics, autoclaving and geographical area of production / E.T. Moran, S.P. Jr. Lall, J.D. Summers // Poultry Sci., 1980. - V. 48. - P. 939-949.

228. Munck, L. Improvement of nutritional value in cereals / L. Munck // Hereditas, 1972. - V.72. - P. 1-128.

229. Neukom, H. Chemistry and properties of the non-starchy polysaccharides (NSP) of wheat flour / H. Neukom // Lebensm. Wiss. Technol., 1976 - V. 9. - P. 143.

230. Okolelova, T. Efficieney of xylanase in diet based on wheat for laying hens / T. Okolelova // II. Europ. Poultry Science revue de Science Avicole Europ. Bremen, 2002. - P. 112.

231. O'Sullivan, C. $\alpha$ - and $\beta$-amylan: Constituents of some cereal / C. O'Sullivan // J.Chem. Soc., 1882. - V. 41. - P. 24-32.

232. Patel, M.B. The nutritive value of rue for chick growth: Effekt of various levers, geogrfphical areal of production and procaine penicillin supplement / M.B. Patel, J. McGinnis // Poultury Sci., 1980. - V. 55. - P. 418-424.

233. Perlin, A.S. Isolation and composition of the solusle pentosans of wheat flour / A.S. Perlin // Cereal Chem., 1951a. - V. 28. - P. 370-381.

234. Perlin, A.S. Structure of the soluble pentosans of wheat flour / A.S. Perlin // Cereal. Chem., 1951b. - V. 28. - P. 382-393.

235. Podrasky, V. Some characteristics of cereal gums / V. Podrasky // Chem. Ind. (London), 1964. - V. 2. - P. 712-713.

236. Polanowski, A. Trypsin inhibitor from rye seeds / A. Polanowski / Acta Biochim. // Pol., 1967. - №14. - P. 389-395.

237. Pomeranz, Y. Structure and mineral composition of cereal aleurone cells as shown by scanning electron microscopy / Y. Pomeranz // Cereal Chem., 1963. V.50. - P. 504-511. 
238. Preece, I.A. Non-starchy polysaccharides of cereal grains.III. Higher mole cular weigt gums of common cereals / I.A. Preece, R. Hobkirk // J. Inst. Brewing., 1953. - V. 59. - P. 385-392.

239. Preece, I.A. Non-starchy polysaccharides of cereal grains.II. Distribution of water - soluble gum-like materials in cereals / I.A. Preece, K.C. Machenzie // J. Inst. Brewing., 1952. - V. 49. - P. 457-464.

240. Preißinger, W. Einsatz von Roggen in aufgewerteten Rationen für Milchkühe / W. Preißinger, A. Obermaier, B. Spann // Forum angewandte Forschung in der Rinder- u. Schweinefütterung, Fulda 2003. - Herausgeber: VLK, Bonn S. 30-33.

241. Preißinger, W. Vier kg Roggen pro Kuh und Tag. / W. Preißinger // Broschüre Roggenforum „Roggen in Fütterungsversuchen leistungsstark!“, Ergebnisse aus Fütterungsversuchen mit Schweinen und Rindern, 2004.

242. Rakowska, M. Eucarpia Conference on Rye / M. Rakowska, K. Raczynska-Bojanowska, D. Boros. Rostanga, Sweden, 11-13 June, 1985. - P. 87.

243. Rakowska, M. Pentosans in rye / M. Rakowska // Vortr. Pflanzenzuchtung. - 1996. - №35. - P. 254.

244. Saini, H.S. Fractionation and evaluation of triticale pentosans: Comparison with wheat and rye / H.S. Saini, R.J. Henry // Cereal Chem., 1989. - V. 66. - P. 11.

245. Salmon, J. Quekques remarques sur letat physique et le comportement histochimique des globoids / J. Salmon // Sci. Paris., 1940. - V.31 - - P. 1425-145.

246. Shibuya, N. Structure of hemicellulose insolated from rice endosperm cell wall: Mode of linkages and sequenas in xyloglucan, $\beta$-glukan and arabinoxylan / N. Shibuya, T. Iwasaki // Agric. Biol. Chem., 1978. - V. 42. - P. 2267.

247. Smith, M.M. Occurrence and nature of ferulic acid substitution of cellwall polysaccharides in graminaceous plants / M.M. Smith, R.D. Hartley // Carbohydr. Res., 1983. - V. 118. - P. 65.

248. Sosulski, J. Free, esterefied and insoluble - bound phenolic acides. III. Composition of phenolic acides in cereal and potato flours / J. Sosulski, K. Krygier, I. Hogge // J. Adric. Food Chem., 1982. - V. 30. - P. 337.

249. Stasiuk, M. Cellular \& molecular biology letters / M. Stasiuk, A.. Kozubek - 1996. - V. 1.

250. Stevens, J. The distribution of trehalase, suctose, L-emylase, glucoamylase and lactase along the small intestine of five pigs / J. Stevens, D. Kidder // Brit. J. Nutrit., 1972. - V.28 - №1. - P. 129-137.

251. Theander, O. The chemistry of dietary fibres / O. Theander // Caslon Press, Stockholm. - 1977. - P. 23-30.

252. Tluscik, F. Bilans i metabolism +-n-alkilorezorcynoli u szczurow. Submtted to Acta Alimentaria Polomica / F. Tluscik, R. Kupiec, M. Rakowska. 1988. - P. 43-50.

253. Udy, D.S. The intrinsic viscositis of the water-soluble components of wheat flour / D.S. Udy // Cereal Chem., 1956. - V. 33. - P. 67-74.

254. Waite, R. Corrod A.R.N. The structural carbo hydrates of grasses / R. Waite, A.R.N. Corrod // J. Sci. Food. Agr., 1959. - V. 10. - P. 308-317. 
255. Weipert, D. Rye and Triticale / C.J. Henry, P.S. Kettwell // Cereal Grain Quality, Chamman and Hall, London, 1996. - P. 205-224.

256. Weipert, D. Rye and Triticale. In Henry C.J., Kettwell P.S. (Eds.) / D. Weipert. Cereal Grain Qualitty, Chmman and Hall, London, 1996a. - P. 205-224.

257. Weipert, D. Pentosans in rye / D. Weipert // Vortr.Pflanzenzuchtung. 1996b. - №35. - P. 85-94.

258. Weipert, D. The Pentosan-Starch Ratio in Quality of Milled Rye Products / D. Weipert, H. Zwingelberg // Cereals for Food and Beverages (Ac. Press). 1980. - P. 459-512.

259. Weipert, D. Description of processing value of new in 1995 released winter and spring rye kultivars / D. Weipert // Getreide, Mehl und Brot, 1996c. V.50. - №2. - P. 67-69.

260. Weipert, D. A. Contribution to ensimation of the processing value of rye / D. A. Weipert // Getreide, Mehl und Brot, 1983. - V.37. - №8. - P. 229-234.

261. Weipert, D. Assesment on rye and rye milling products. In Seibel W., Steller W. (Eds) Rye - Production, spread and marketing Behr's / D. Weipert, M.-J. Bruemmer. - Verlag Hamburg, 1988. - P. 125-129.

262. Wieringa, G.W. On the occurrence of growth inhibiting substances in rye / G.W. Wieringa // H. Veenmann en Zonen NV: Wageningen, The Netherlands, 1967. - P. 68 .

263. Willegas, E. Variability in the lysine content of wheat, rye and Triticale proteins / E. Willegas, C. E McDonald, K. A. Gilles // Cereal Chem. - 1970. - V. 47. - №1. P. 89-93.

264. www.ryebelt.com

265. Yamazari, W.T. The concentration of a factor in soft wheat flours affecting cookie quality / W.T. Yamazari // Cereal Chem., 1955. - V.32. - P. 26-37. 


\section{ОГЛАВЛЕНИЕ}

ВВЕДЕНИЕ ............................................... 3

1. ПИТАТЕЛЬНАЯ ЦЕННОСТЬ ЗЕРНА ОЗИМОЙ РЖИ ................. 4

1.1. Зерно ржи в рационе кормления сельскохозяйственных животных ... 4

1.2. Питательная ценность зерна ржи ............................... 13

1.2.1. Энергетическая питательность зерна озимой ржи ................. 13

1.2.2. Содержание в зерне переваримого протеина и аминокислот ....... 14

1.2.3. Содержание в зерне углеводов и жира …..................... 17

1.2.4. Содержание минеральных веществ в зерне озимой ржи ............ 23

1.2.5. Содержание витаминов ..................................... 26

2. АНТИПИТАТЕЛЬНЫЕ СВОЙСТВА ЗЕРНА ОЗИМОЙ РЖИ .......... 28

2.1. Вещества, снижающие кормовую ценность зерна ржи .............. 28

2.2. Пентозаны как основной фактор, снижающий кормовую ценность зерна озимой ржи

2.3. Состав и свойства пентозанов .................................. 37

3. ПЕНТОЗАНЫ И ВЯЗКОСТЬ ВОДНОГО ЭКСТРАКТА ЗЕРНА РЖИ.. 43

3.1. Вязкость водного экстракта - показатель для оценки содержания водорастворимых пентозанов в зерне озимой ржи

4. КОРМОВЫЕ КАЧЕСТВА ЗЕРНА СОРТОВ ОЗИМОЙ РЖИ .......... 45

4.1. Питательность зерна сортов озимой ржи ....................... 45

4.2. Сорт и содержание пентозанов в зерне ржи ....................... 51

4.3. Активность пентозаназ ........................................ 58

5. ВЯЗКОСТЬ ВОДНОГО ЭКСТРАКТА ЗЕРНА РЖИ В ЗАВИСИМОСТИ ОТ СРОКА ХРАНЕНИЯ

6. СПОСОБЫ ПОДГОТОВКИ ЗЕРНА РЖИ К СКАРМЛИВАНИЮ ...... 63 БИБЛИОГРАФИЧЕСКИЙ СПИСОК ............................... 77 
